DOE/ID-22165

CHEMICAL AND RADIOCHEMICAL CONSTITUENTS IN WATER FROM WELLS IN THE VICINITY OF THE NAVAL REACTORS FACILITY, IDAHO NATIONAL ENGINEERING AND ENVIRONMENTAL LABORATORYY, IDAHO, 1997-98

U.S. GEOLOGICAL SURVEY

Open-File Report 00-236

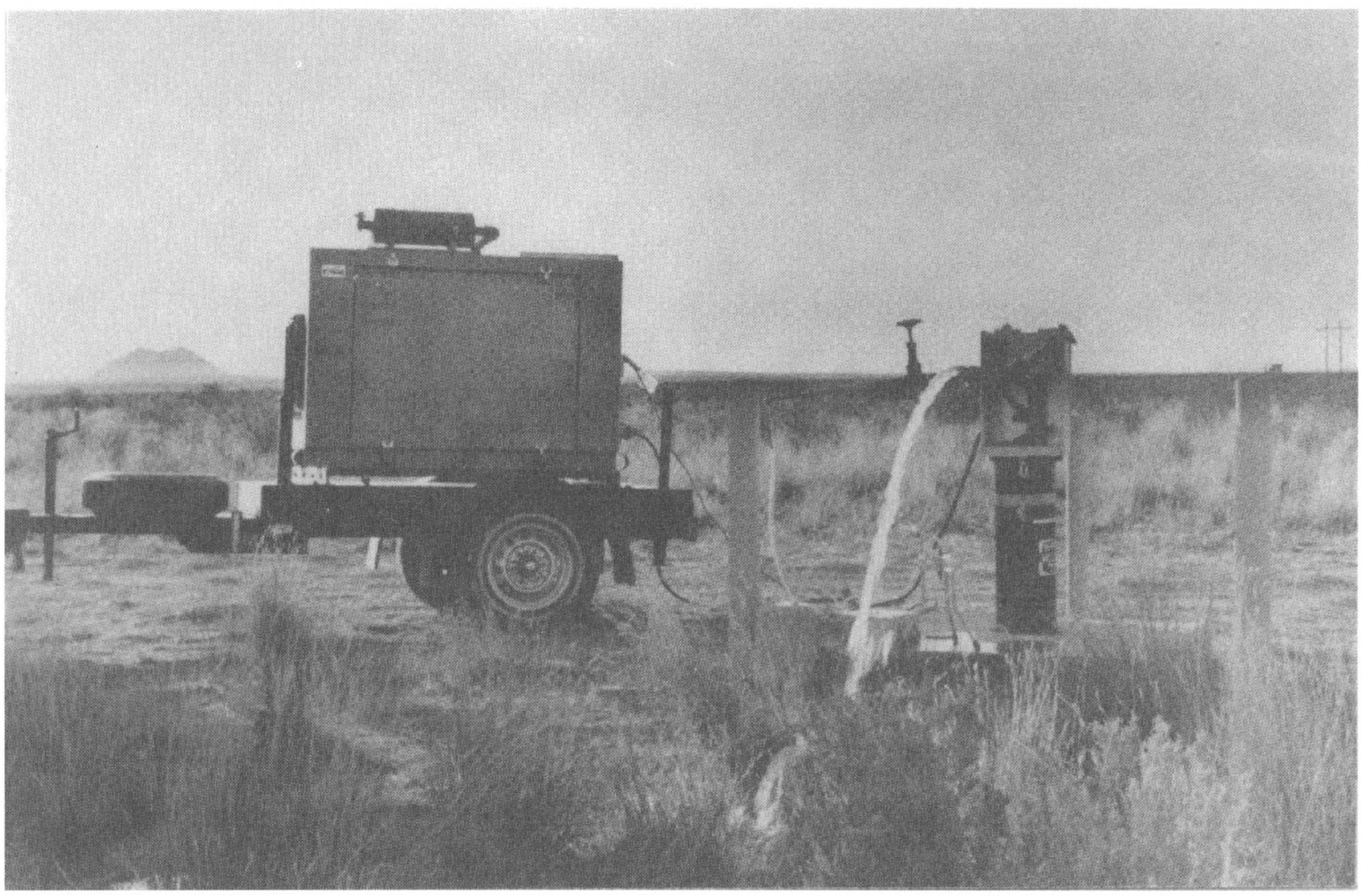

Prepared in cooperation with the U.S. DEPARTMENT OF ENERGY 


\section{CHEMICAL AND RADIOCHEMICAL CONSTITUENTS IN WATER FROM WELLS IN THE VICINITY OF THE NAVAL REACTORS FACILITY, IDAHO NATIONAL ENGINEERING AND ENVIRONMENTAL LABORATORY, IDAHO, 1997-98}

By Roy C. Bartholomay, LeRoy L. Knobel, Betty J. Tucker, and Brian V. Twining

U.S. GEOLOGICAL SURVEY

Open-File Report 00-236

Prepared in cooperation with the U.S. DEPARTMENT OF ENERGY

Idaho Falls, Idaho June 2000 


\section{U.S. DEPARTMENT OF THE INTERIOR BRUCE BABBITT, Secretary}

U.S. GEOLOGICAL SURVEY

Charles G. Groat, Director

Any use of trade, product, or firm names in this publication is for descriptive purposes only and does not constitute endorsement by the U.S. Government.

For additional information write to:

U.S. Geological Survey

INEEL, MS 1160

P.O. Box 2230

Idaho Falls, ID 83403
Copies of this report can be purchased from:

U.S. Geological Survey

Information Services

Box 25286, Federal Center

Denver, CO 80225 


\section{CONTENTS}

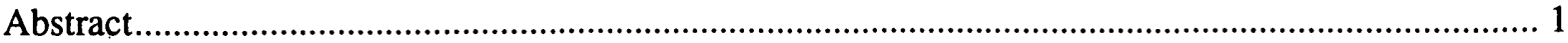

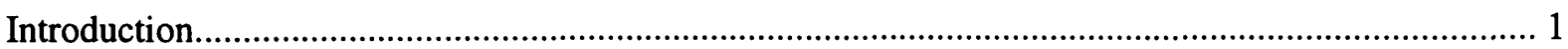

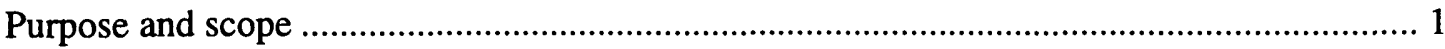

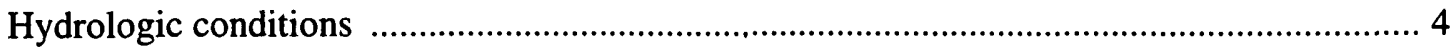

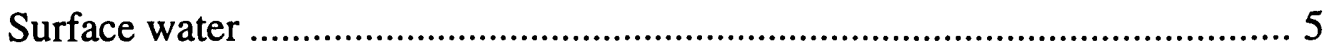

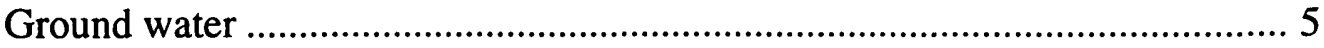

Guidelines for interpreting results of radiochemical analyses......................................... 5

Guidelines for interpreting results of inorganic and organic analyses ............................... 7

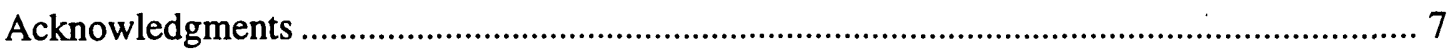

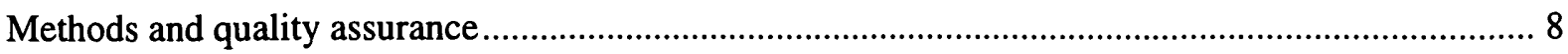

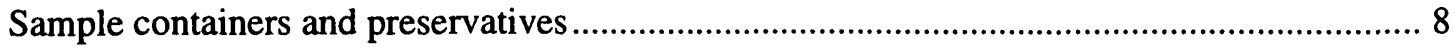

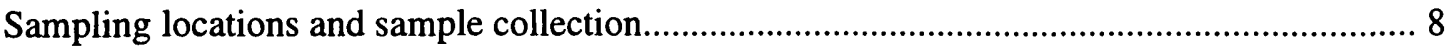

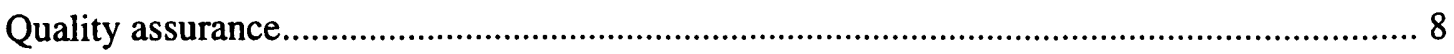

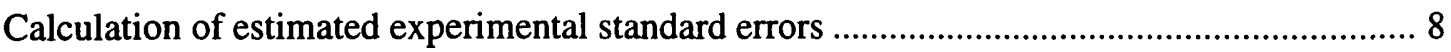

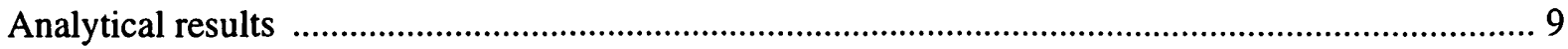

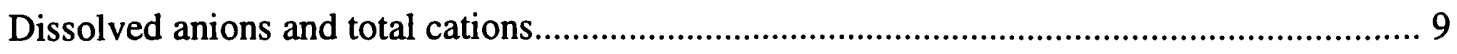

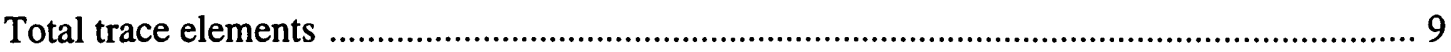

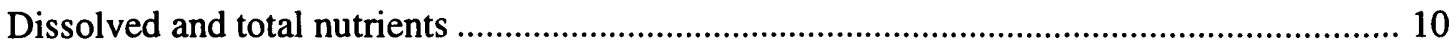

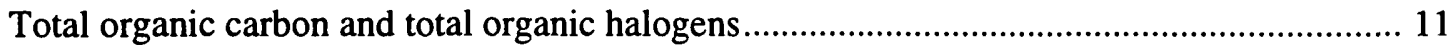

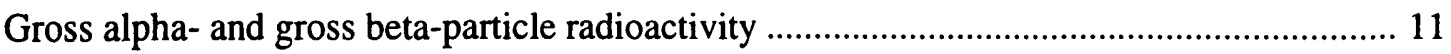

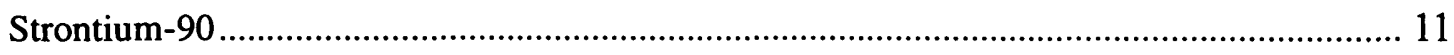

Tritium

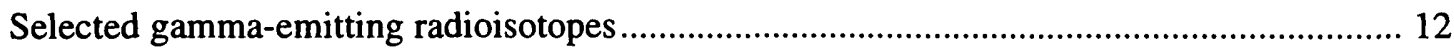

Regulatory volatile and base/neutral organic compounds .............................................. 12

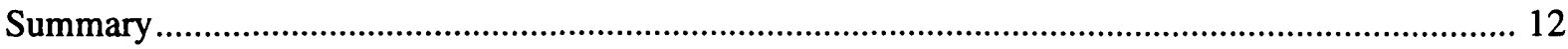

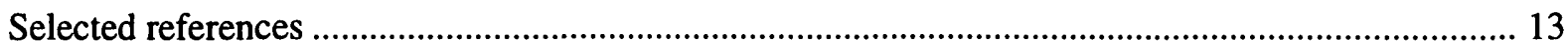

\section{FIGURES}

Figures 1-2. Maps showing:

1. Location of the Idaho National Engineering and Environmental Laboratory, Naval Reactors Facility, and other selected facilities ........................................................ 2

2. Location of wells, Naval Reactors Facility and vicinity, Idaho National

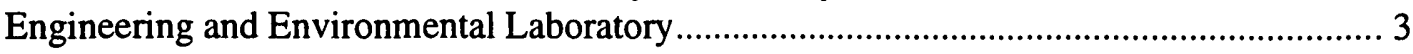

3. Water levels in two wells near the Naval Reactors Facility ............................................

\section{TABLES}

Table 1. Containers and preservatives used for water samples, Naval Reactors

Facility and vicinity

2. Results of measurements of water for alkalinity, $\mathrm{pH}$, specific conductance, temperature, and turbidity, and calculated total dissolved solids, Naval

Reactors Facility and vicinity

3. Concentrations of dissolved anions and total cations in water, Naval Reactors

Facility and vicinity 
4. Statistical parameters for dissolved anions and total cations, by well.

5. Concentrations of selected total trace elements in water, Naval Reactors Facility and vicinity

6. Statistical parameters for selected total trace elements, by well

7. Concentrations of dissolved and total nutrients, total organic carbon, and total organic halogens in water, Naval Reactors Facility and vicinity.

8. Statistical parameters for dissolved and total nutrients, total organic carbon, and total organic halogens, by well

9. Concentrations of gross alpha-particle radioactivity, gross beta-particle radioactivity, strontium-90, tritium, and selected isotopes from gamma spectroscopy in water, Naval Reactors Facility and vicinity

10. Statistical parameters for gross alpha-particle radioactivity, gross beta-particle radioactivity, gamma spectroscopy, strontium-90, and tritium, by well 48

11. Regulatory volatile organic compounds for which water samples were analyzed 51

12. Base/neutral organic compounds for which water samples were analyzed 52

\section{CONVERSION FACTORS, VERTICAL DATUM, AND ABBREVIATED UNITS}

Multiply

foot (ft)

inch (in.)

mile (mi)

square mile $\left(\mathrm{mi}^{2}\right)$

acre-foot (acre-ft)

foot per mile ( $\mathrm{ft} / \mathrm{mi})$

picocurie per liter $(\mathrm{pCi} / \mathrm{L})$

By
0.3048
25.4
1.609
2.590
, 233
.1894
.037

To obtain

meter

millimeter

kilometer

square kilometer

cubic meter

meter per kilometer

becquerel per liter

For temperature, degrees Celsius $\left({ }^{\circ} \mathrm{C}\right)$ can be converted to degrees Fahrenheit $\left({ }^{\circ} \mathrm{F}\right)$ by using the equation:

${ }^{\circ} \mathrm{F}=(1.8)\left({ }^{\circ} \mathrm{C}\right)+32$.

Sea level: In this report, "sea level" refers to the National Geodetic Vertical Datum of 1929-a geodetic datum derived from a general adjustment of the first-order level nets of the United States and Canada, formerly called Sea Level Datum of 1929.

Abbreviated units used in report: $\mathrm{mg} / \mathrm{L}$ (milligram per liter); $\mu \mathrm{g} / \mathrm{L}$ (microgram per liter); $\mathrm{pCi} / \mathrm{L}$ (picocuries per liter). 


\title{
CHEMICAL AND RADIOCHEMICAL CONSTITUENTS IN WATER FROM WELLS IN THE VICINITY OF THE NAVAL REACTORS FACILITY, IDAHO NATIONAL ENGINEERING AND ENVIRONMENTAL LABORATORY, IDAHO, 1997-98
}

\author{
by Roy C. Bartholomay, LeRoy L. Knobel, Betty J. Tucker, and Brian V. Twining
}

Abstract

The U.S. Geological Survey, in response to a request from the U.S. Department of Energy's Pittsburgh Naval Reactors Office, Idaho Branch Office, sampled water from 13 wells during 1997-98 as part of a long-term project to monitor water quality of the Snake River Plain aquifer in the vicinity of the Naval Reactors Facility, Idaho National Engineering and Environmental Laboratory, Idaho. Water samples were analyzed for naturally occurring constituents and man-made contaminants. A total of 91 samples were collected from the 13 monitoring wells. The routine samples contained detectable concentrations of total cations and dissolved anions, and nitrite plus nitrate as nitrogen. Most of the samples also had detectable concentrations of gross alpha- and gross beta-particle radioactivity and tritium. Fourteen qualityassurance samples also were collected and analyzed; seven were field-blank samples, and seven were replicate samples. Most of the field blank samples contained less than detectable concentrations of target constituents; however, some blank samples did contain detectable concentrations of calcium, magnesium, barium, copper, manganese, nickel, zinc, nitrite plus nitrate, total organic halogens, tritium, and selected volatile organic compounds.

\section{INTRODUCTION}

The Idaho National Engineering and Environmental Laboratory (INEEL), encompassing about $890 \mathrm{mi}^{2}$ of the eastern Snake River Plain in southeastern Idaho (fig. 1), is operated by the U.S. Department of Energy (DOE). INEEL facilities are used in the development of peacetime atomicenergy applications, nuclear safety research, defense programs, and advanced energy concepts. At the Naval Reactors Facility (NRF) (fig. 2), one facility at the INEEL, small amounts of some constituents have been released to the environment as described in two NRF Remedial Investigation/Feasibility Studies (Bettis Atomic Power Laboratory, 1994, 1997).

This study was conducted by the U.S. Geological Survey (USGS) in cooperation with the DOE's Pittsburgh Naval Reactors Office, Idaho Branch Office (IBO). IBO is responsible for the NRF at the INEEL. IBO requires information about the mobility of radionuclide- and chemical-waste constituents in the Snake River Plain aquifer. Wasteconstituent mobility is determined principally by (1) the rate and direction of ground-water flow; (2) the locations, quantities, and methods of waste disposal; (3) waste-constituent chemistry; and (4) the geochemical processes taking place in the aquifer (Orr and Cecil, 1991, p. 2).

\section{Purpose and Scope}

In 1989, IBO requested that the USGS initiate a water-quality data-collection program in the vicinity of the NRF at the INEEL (fig. 1). The purpose of the data-collection program is to provide the IBO with water-chemistry data to evaluate the effect of NRF activities on the water quality of the Snake River Plain aquifer.

Through 1995, the data-collection program has consisted of three rounds of sample collection.

Round one was a one-time sampling of each well for a comprehensive suite of chemical constituents that approximates those contained in the U.S. Environmental Protection Agency's Ground-Water Monitoring List-Appendix IX (U.S. Environmental Protection Agency, 1989, p. 636-642). Round two consisted of bimonthly collection of samples five times from each well that were analyzed for the chemical constituents listed in Appendix IIIEPA Interim Primary Drinking Water Standards, 


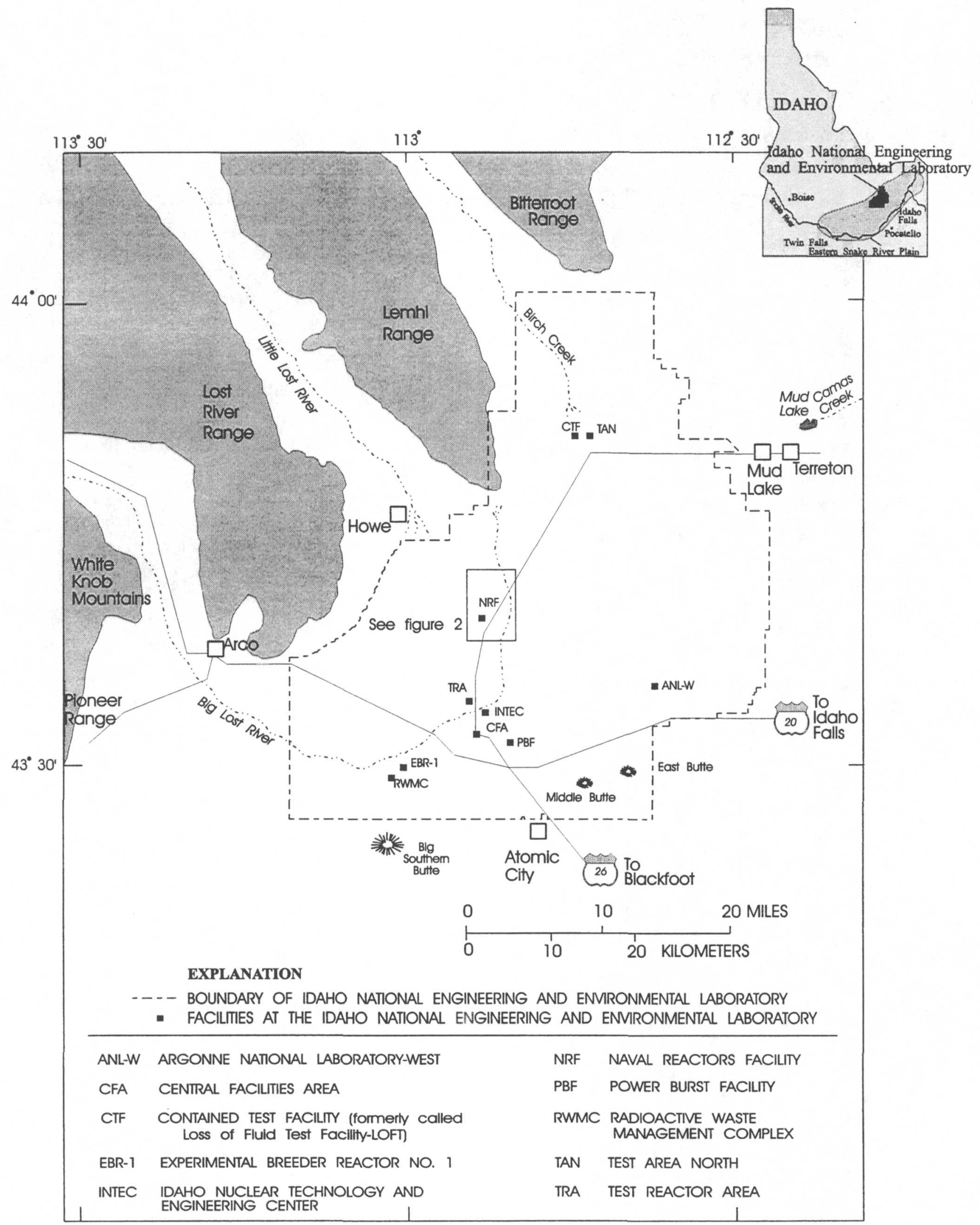

Figure 1. Location of the Idaho National Engineering and Environmental Laboratory, Naval Reactors Facility, and other selected facilities. 


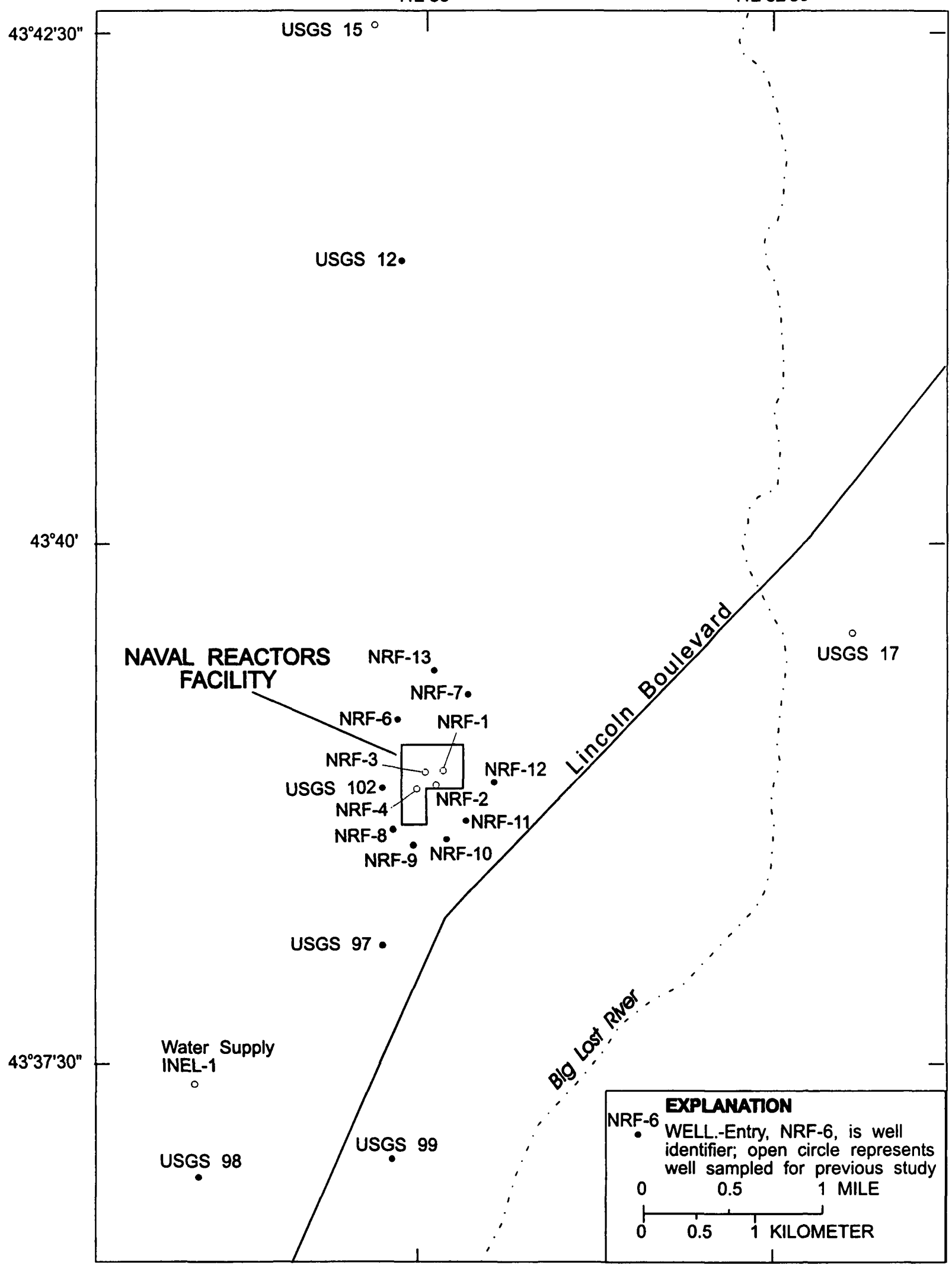

Figure 2. Location of the wells, Naval Reactors Facility and vicinity, Idaho National Engineering and Environmental Laboratory. 
the constituents listed as parameters establishing ground-water quality, and selected measurements used as indicators of ground-water contamination (U.S. Environmental Protection Agency, 1989, p. 660-661, 730). Additional constituents analyzed during round two included copper, nickel, zinc, and extractable acid and base/neutral compounds. Round three samples were collected quarterly through 1995. Constituents analyzed in 1994 included chloride, chromium, iron, lead, mercury, nickel, nitrate as nitrogen, silver, sodium, and sulfate. Other round-three measurements were gross alpha- and gross beta-particle radioactivity, $\mathrm{pH}$, specific conductance, and total organic carbon (TOC). The round-three sampling program was expanded in 1995 to include analyses for aluminum, antimony, arsenic, barium, beryllium, cadmium, copper, manganese, selenium, thallium, tritium, and zinc. As a result of expanded laboratory procedures, rounds one through three of the sample-collection program included analyses for constituents in addition to those listed above. Results of analyses of rounds one through three samples are presented by Knobel, Bartholomay, and others (1992), Bartholomay and others (1993), Tucker and others (1995), and Bartholomay, Knobel, and Tucker (1997).

An analysis by Westinghouse Electric Corporation of the water chemistry data collected for the NRF monitoring program during 1989-95 indicated that several changes to the program would improve the overall usefulness of the data. As a result, several older wells were eliminated from the program and replaced by monitoring wells specifically constructed to meet NRF needs and strategically placed to better intercept chemical plumes in ground water. In order to differentiate between the data generated from the NRF sampling program in rounds one through three (1989-95) and subsequent data (1996), the samples collected in 1996 were designated round-four samples (Knobel and others, 1999). Wells sampled in rounds one through three that were eliminated from the program are the four water-supply production wells with line shaft turbine pumps (NRF-1, $-2,-3$, and -4 ; fig. 2) and three monitoring wells (USGS 15, USGS 17, and Water Supply INEL-1; fig. 2) which have dedicated submersible pumps. The six newly constructed monitoring wells that were added to the sampling program in 1996 were NRF-8, -9, $-10,-11,-12$, and -13 (fig. 2). All of these wells and the older monitoring wells which remain in the monitoring network (NRF-6, NRF-7, USGS 12, $97,98,99$, and 102; fig. 2) have dedicated submersible pumps.

At the end of 1996, NRF increased its validation requirement for ground-water data on the basis of documents that supported the Record of Decision for the industrial waste ditch and NRF landfills. The additional cost for the USGS National Water Quality Laboratory (NWQL) was too great to supply the required documentation. Consequently, NRF personnel sampled the wells during the first quarter of 1997. After further consideration of the program, it was determined that the sampling could be done under the USGS Department of Defense Environmental Conservation (DODEC) Program. Under this program, samples are contracted to Quanterra Environmental Laboratory Services, a laboratory that routinely handles documentation requirements of regulatory programs. Starting in June of 1997, analyses of water samples collected by the USGS were analyzed by the Quanterra laboratory. Results from the 1997-98 sampling are presented in this report. These samples are designated round-five samples. Location of wells sampled are shown in figure 2 .

The constituent list for round-five samples was modified slightly from round four because availability of analyses at the laboratory. The constituents included in the round-five sampling program are presented along with analytical results in tables 3-12 at the back of this report. Field measurements and calculations for round-five samples include alkalinity as $\mathrm{CaCO}_{3}, \mathrm{pH}$, specific conductance, temperature, total dissolved solids (TDS), and turbidity. Total dissolved solids were estimated by multiplying specific conductance by .543 as determined by Olmstead (1962, figure 5). Round-five samples were collected quarterly at each well.

\section{Hydrologic Conditions}

The Snake River Plain aquifer is one of the most productive aquifers in the United States (U.S. Geological Survey, 1985, p. 193). The aquifer underlies the eastern Snake River Plain and con- 
sists of a thick sequence of basalts and sedimentary interbeds filling a large, arcuate, structural basin in southeastern Idaho (fig. 1).

\section{Surface Water}

The Big Lost River drains more than $1,400 \mathrm{mi}^{2}$ of mountainous area that includes parts of the Lost River Range and the Pioneer Range west of the INEEL (fig. 1). Flow in the Big Lost River infiltrates to the Snake River Plain aquifer along its channel and in sinks and playas near the river's terminus. Since 1958, excess runoff has been diverted to spreading areas in the southwestern part of the INEEL where much of the water rapidly infiltrates to the aquifer. Other surface drainages that provide recharge to the Snake River Plain aquifer at the INEEL include the Little Lost River, Birch Creek, and Camas Creek (fig. 1) (Bartholomay, Tucker, and others, 1997, p. 18).

\section{Ground Water}

Recharge to the Snake River Plain aquifer is principally from infiltration of applied irrigation water, infiltration of streamflow, and ground-water inflow from adjoining mountain drainage basins. Some recharge may be from direct infiltration of precipitation, although the small amount of annual precipitation on the plain ( 8 in. at the INEEL), evapotranspiration, and the great depth to water (in places exceeding $900 \mathrm{ft}$ ) probably minimize this source of recharge (Orr and Cecil, 1991, p. 22-23).

Water in the Snake River Plain aquifer moves principally through fractures and interflow zones in the basalt. Most ground water moves through the upper $800 \mathrm{ft}$ of saturated rocks. Hydraulic conductivities of basalt in the upper $800 \mathrm{ft}$ of the aquifer, estimated from INEEL-wide transmissivity data, are from 0.0086 to 5,500 ft/day (Ackerman, 1991, p. 30). Estimated hydraulic conductivities in a 10,365-ft deep test hole near NRF are smaller; at depths exceeding $1,500 \mathrm{ft}$, hydraulic conductivities are from 0.002 to $0.03 \mathrm{ft} /$ day (Mann, 1986, p. 21). The effective base of the Snake River Plain aquifer at the INEEL is from about 815 to $1,710 \mathrm{ft}$ below land surface (Anderson and others, 1996, table 3, p. 23).
Depth to water in wells completed in the Snake River Plain aquifer is from about $200 \mathrm{ft}$ below land surface in the northern part of the INEEL to more than $900 \mathrm{ft}$ in the southeastern part; in the vicinity of NRF, depth to water is about $375 \mathrm{ft}$ below land surface. In March-May 1995, the altitude of the water table was about $4,575 \mathrm{ft}$ above sea level near Test Area North (fig. 1) and about 4,425 ft above sea level near the Radioactive Waste Management Complex (fig. 1); near the NRF, the water table was about $4,475 \mathrm{ft}$ above sea level. Water generally flowed southward and southwestward beneath the INEEL at an average hydraulic gradient of about $4 \mathrm{ft} / \mathrm{mi}$; however, significant local variation in flow direction is common. Beneath the NRF, water generally flowed southward. From March-May 1991 to March-May 1995, water-level changes in INEEL wells ranged from an 8.5-ft decline north of the NRF to a 2.5-ft decline in wells in the southern part of the INEEL; near the NRF, the water-level decline was about 6 to $8 \mathrm{ft}$. Water levels generally declined at the INEEL during 1992-95 because of drought (Bartholomay, Tucker, and others, 1997, p. 20-25), but since 1995, have risen (fig. 3).

Ground water moves southwestward from the INEEL and eventually discharges as springs along the Snake River downstream from Twin Falls, about 100 mi southwest of the INEEL (fig. 1). Approximately 3.7 million acre-ft of ground water was discharged in 1995 (C.E. Berenbrock, USGS, written commun., 1996).

\section{Guidelines for Interpreting Results of Radiochemical Analyses}

Concentrations of radionuclides are reported with an estimated sample standard deviation, $s$, that is obtained by propagating sources of analytical uncertainty in measurements. The following guidelines for interpreting analytical results are based on an extension of a method proposed by Currie (1984).

In the analysis for a particular radionuclide, laboratory measurements are made on a target sample and a prepared blank. Instrument signals for the sample and the blank vary randomly. Therefore, it is essential to distinguish between two key aspects of the problem of detection: (1) the instrument signal for the sample must be larger than the signal 
ALTITUDE OF WATER LEVEL, IN FEET ABOVE SEA LEVEL

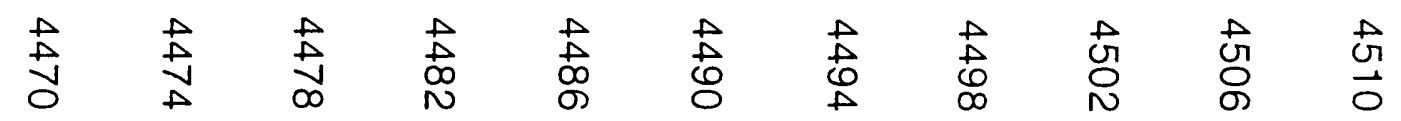

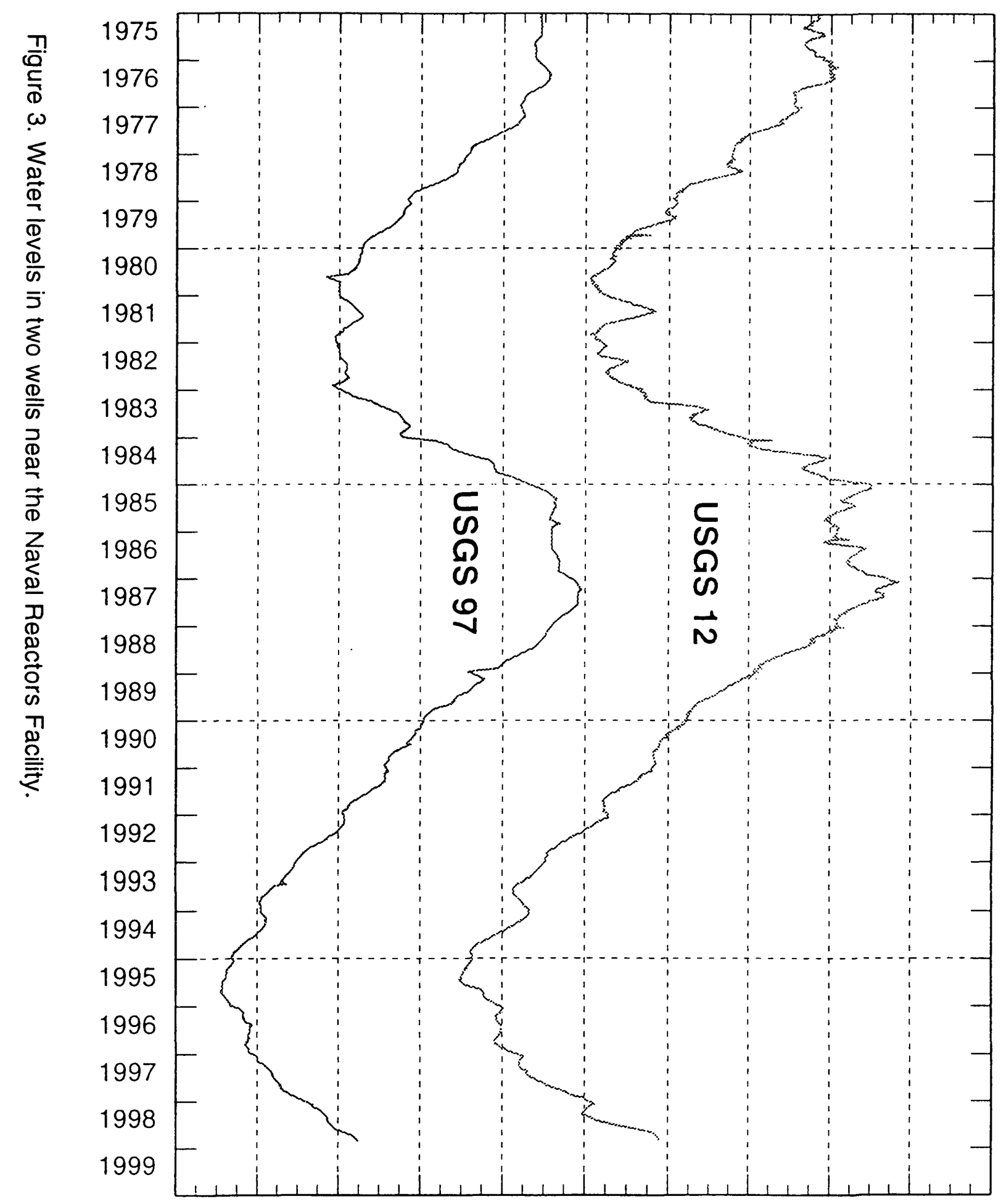


observed for the blank before the decision can be made that the radionuclide was detected; and (2) an estimation must be made of the minimum radionuclide concentration that will yield a sufficiently large observed signal before the correct decision can be made for detection or nondetection of the radionuclide. The first aspect of the problem is a qualitative decision based on an observed signal and a definite criterion for detection. The second aspect of the problem is an estimation of the detection capabilities of a given measurement process.

In the laboratory, instrument signals must exceed a critical level of $1.6 \mathrm{~s}$ before the qualitative decision can be made as to whether the radionuclide was detected. At $1.6 \mathrm{~s}$, there is a 95 -percent probability that the correct conclusion-not detected-will be made. Given a large number of samples, as many as 5 percent of the samples with measured concentrations larger than or equal to $1.6 \mathrm{~s}$, which were concluded as being detected, might not contain the radionuclide. These measurements are referred to as false positives and are errors of the first kind in hypothesis testing.

Once the critical level of $1.6 \mathrm{~s}$ has been defined, the minimum detectable concentration may be determined. Radionuclide concentrations that equal $3 \mathrm{~s}$ represent a measurement at the minimum detectable concentration. For true concentrations of $3 \mathrm{~s}$ or larger, there is a 95-percent or larger probability that the radionuclide was detected in a sample. In a large number of samples, the conclusion-not detected-will be made in 5 percent of the samples that contain true concentrations at the minimum detectable concentration of $3 \mathrm{~s}$. These measurements are referred to as false negatives and are errors of the second kind in hypothesis testing.

True radionuclide concentrations between 1.6s and $3 \mathrm{~s}$ have larger errors of the second kind. That is, there is a larger-than-5-percent probability of false negative results for samples with true concentrations between $1.6 \mathrm{~s}$ and $3 \mathrm{~s}$. Although the radionuclide might have been detected, such detection may not be considered reliable; at $1.6 \mathrm{~s}$, the probability of a false negative is about 50 percent.

The critical level and minimum detectable concentration are based on counting statistics alone and do not include systematic or random errors inherent in laboratory procedures. The values $1.6 \mathrm{~s}$ and $3 \mathrm{~s}$ vary slightly with background or blank counts, with the number of gross counts for individual analyses, and for different radionuclides. In this report, radionuclide concentrations less than $3 \mathrm{~s}$ are considered to be below a "reporting level". The critical level, minimum detectable concentration, and reporting level aid the reader in the interpretation of analytical results and do not represent absolute concentrations of radioactivity which may or may not have been detected.

Many analytical results of environmental radioactivity measurements are at or near zero. If the true concentration for a given radionuclide is zero, a given set of analytical results for that radionuclide should be distributed about zero, with an equal number of negative and positive measurements. Negative analytical results occur if the radioactivity of a water sample is less than the background radioactivity or the radioactivity of the prepared blank sample in the laboratory (American Society for Testing and Materials, 1992, p. 126; Knobel, Orr, and Cecil, 1992, p. 51).

\section{Guidelines for Interpreting Results of Inorganic and Organic Analyses}

The term "reporting level" used for radiochemical analyses should not be confused with the term "reporting limit," used for inorganic and organic analyses. In this report, the term "reporting limit" is the lowest level at which measurements become quantitatively meaningful (Quanterra Environmental Services, 1998). Because of unpredictable matrix effects on detection limits, the laboratory reporting limits are set somewhat higher than the analytical method detection limits. Because of this, some estimated results are given.

\section{Acknowledgments}

The authors are grateful to Robert Hermandson of the USGS for checking data in the tables and to Richard J. Wagner of the USGS and Kelly D. Willie and Adolfo Sierra of Bechtel-Bettis Corporation for technically reviewing the manuscript. 


\section{METHODS AND QUALITY ASSURANCE}

The methods used for collecting water samples generally followed the guidelines established by the USGS (Stevens and others, 1975; Wood, 1981; Claassen, 1982; W.L. Bradford, USGS, written commun., 1985; Hardy and others, 1989; Wilde and others, 1998). Descriptions of methods used for analysis are found in Quanterra Environmental Services (1998) and Thatcher and others (1977). The methods used in the field and the qualityassurance practices are described in following sections.

\section{Sample Containers and Preservatives}

Sample containers and preservatives differed depending on the constituent(s) for which analyses were requested. Samples analyzed by Quanterra Environmental Services were placed in containers and preserved in accordance with bottle manufacturer requirements. Containers and preservatives were supplied by the Quanterra laboratory. The containers and preservatives used for this study are listed in table 1 (all tables located at the end of report).

\section{Sampling Locations and Sample Collection}

Samples were collected from 13 monitoring wells (NRF-6, -7, -8, -9, -10, -11, -12, -13, USGS $12,97,98,99$, and 102) equipped with dedicated submersible pumps. NRF-6, -7, -13, and USGS 12 are upgradient of the NRF; USGS 102 is west of NRF; NRF-11 and -12 are east of NRF; and the remaining monitoring wells are downgradient of NRF (fig. 2).

Samples were collected from a portable sampling apparatus attached to dedicated submersible pumps. The apparatus was decontaminated before sampling at each site. Samples were collected after three well-bore volumes of water were purged from each well and field measurements of water temperature, $\mathrm{pH}$, and specific conductance indicated probable hydraulic and chemical stability as described by Mann (1996). After collection, sample containers were sealed with laboratory film, labeled, and stored under secured conditions.
Water samples were placed in ice chests, chilled when appropriate, sealed, and shipped the same day to the laboratory.

Conditions at the sampling site during sample collection were recorded in a field logbook and a chain-of-custody record was used to track samples from the time of collection until delivery to the laboratory. These records are available for inspection at the USGS INEEL Project Office. The results of field measurements and calculations for alkalinity, $\mathrm{pH}$, specific conductance, water temperature, TDS, and turbidity are listed in table 2 .

\section{Quality Assurance}

Internal quality control and the overall qualityassurance practices used by the Quanterra laboratory are described in Quanterra Environmental Services (1998). The water samples were collected by personnel assigned to the INEEL Project Office in accordance with a quality-assurance plan for quality-of-water activities (Mann, 1996), and is available from the USGS INEEL Project Office. Comparative studies to determine agreement between analytical results for water-sample pairs by laboratories involved in the INEEL Project Office's quality-assurance program are summarized by Wegner (1989), Williams (1996), and Williams (1997). Additional quality assurance used for this sampling program included seven fieldblank samples prepared with inorganic-free and organic-free water and seven replicate samples. Bottles for the field-blank samples were filled in the field camper with the respective inorganic and organic-free water. Inorganic-free water was used for the radiochemical analyses. Respective bottles were then opened at the well while sample collection occurred. After collection of the primary sample, a replicate sample was immediately collected. Many organizations use the term "sequential replicate" in place of "replicate" sample.

\section{Calculation of Estimated Experimental Standard Errors}

The analytical results for radionuclides are presented with calculated analytical uncertainties. There is about a 67-percent probability that the true radionuclide concentration is in a range of the 
reported concentration plus or minus the uncertainty. The uncertainties are expressed as one sample standard deviation (s).

The associated uncertainties presented with mean concentrations are experimental standard errors and are an estimate of the uncertainty of the mean concentration. The estimated experimental standard errors (EESE) were calculated using the following equation (Iman and Conover, 1983, p. 158):

where

$$
\operatorname{EESE}=\sigma /(n)^{0.5},
$$

$$
\begin{aligned}
& \sigma=\text { population standard deviation, and } \\
& \mathrm{n}=\text { sample size. }
\end{aligned}
$$

The population standard deviation, $\sigma$, is customarily estimated by $\mathbf{S}$ (Iman and Conover, 1983, p. 106). The $s$ is the square root of the sample variance (Iman and Conover, 1983, p. 100-101).

\section{ANALYTICAL RESULTS}

During the period beginning in June 1997 and ending in November 1998, seven sets of quarterly water samples were collected for round five of the NRF sampling program (table 2). All wells were sampled seven times. Because original samples for purgeable organic compounds and semivolatiles were destroyed at the lab during the August 1998 sampling round, the constituents had to be resampled for wells NRF-8, $-10,-11,-12,-13$, and QAS-63. Because original radionuclide samples for selected radionuclides broke in shipment to the lab during November 1998 sampling, the constituents had to be resampled for NRF-6, -7, $-9,-10$, and USGS 102 (table 2). Quality-assurance samples included field-blank samples; NRF-8 (QAS64), NRF-9 (QAS-62), USGS 12 (QAS-54), USGS 97 (QAS-57), USGS 98 (QAS-60), USGS 99 (QAS-55 and -66), and seven replicate samples: NRF-6 (QAS-59), NRF-7 (QAS-61), NRF-9 (QAS-56), NRF-11 (QAS-58), NRF-12 (QAS-53), USGS 12 (QAS-63), and USGS 102 (QAS-65).

\section{Dissolved Anions and Total Cations}

Water samples were analyzed for concentrations of dissolved chloride and sulfate, and concentrations of total calcium, magnesium, potassium, and sodium (table 3 ). Statistical parameters for these constituents are provided by well in table 4 and were calculated using the data presented in this report.

Mean concentrations of calcium in the 13 wells ranged from $28 \mathrm{mg} / \mathrm{L}$ in NRF-7 to $132 \mathrm{mg} / \mathrm{L}$ in NRF-6. Mean concentrations of chloride ranged from 4.5 to $249 \mathrm{mg} / \mathrm{L}$. Mean concentrations of magnesium ranged from 9.5 to $34 \mathrm{mg} / \mathrm{L}$. Estimated mean concentrations of potassium ranged from 1.8 to $5.0 \mathrm{mg} / \mathrm{L}$. Mean concentrations of sodium ranged from 9.1 to $116 \mathrm{mg} / \mathrm{L}$. Mean concentrations of sulfate ranged from 13.6 to $170 \mathrm{mg} / \mathrm{L}$.

Concentrations in the seven field-blank samples were not detected except for calcium in QAS-62 which had an estimated concentration of 0.061 $\mathrm{mg} / \mathrm{L}$ and calcium and magnesium in QAS-55 which had concentrations of 0.63 and $0.21 \mathrm{mg} / \mathrm{L}$, respectively.

\section{Total Trace Elements}

Water samples collected in 1997-98 were analyzed for concentrations of total aluminum, antimony, arsenic, barium, beryllium, cadmium, chromium, copper, iron, lead, manganese, mercury, nickel, selenium, silver, thallium, and zinc (table 5). Statistical parameters for selected trace elements are provided by well in table 6 and were calculated using the data presented in this report.

Aluminum.-The mean concentration of aluminum for seven samples from NRF-13 was 4,600 $\mu \mathrm{g} / \mathrm{L}$; however, aluminum concentrations were not detected in samples from most wells.

Antimony.-The estimated mean concentration of antimony for five samples from NRF-6 was $0.71 \mu \mathrm{g} / \mathrm{L}$; however, antimony concentrations were not detected in samples from most wells.

Arsenic.- The estimated mean concentration of arsenic for six samples from NRF-6 was $3.8 \mu \mathrm{g} / \mathrm{L}$; however, arsenic concentrations were not detected in samples from most wells.

Barium.-Estimated mean concentrations ranged from $50 \mu \mathrm{g} / \mathrm{L}$ in USGS 98 to $158 \mu \mathrm{g} / \mathrm{L}$ in NRF-12. 
Beryllium.-Concentrations were not detected in all but one sample. NRF-6 had one sample with an estimated concentration of $0.023 \mu \mathrm{g} / \mathrm{L}$.

Cadmium.-The estimated mean concentration of cadmium in five samples from USGS 98 was $0.18 \mu \mathrm{g} / \mathrm{L}$; however, cadmium concentrations were not detected in samples from most wells.

Chromium.-Estimated mean concentrations ranged from $4.7 \mu \mathrm{g} / \mathrm{L}$ in USGS 98 to $66.5 \mu \mathrm{g} / \mathrm{L}$ in NRF-12.

Copper.-The estimated mean concentration of copper in five samples from NRF-7 was $18 \mu \mathrm{g} / \mathrm{L}$; however, copper concentrations were not detected in samples from most wells.

Iron.-The mean concentration of iron in seven samples from NRF-13 was $4,960 \mu \mathrm{g} / \mathrm{L}$; iron concentrations were not detected in samples from several wells.

Lead.-The estimated mean concentration of lead in seven samples from USGS 98 was $5.5 \mu \mathrm{g} / \mathrm{L}$; however, lead concentrations were not detected in samples from most wells.

Manganese.-Estimated mean concentrations ranged from $1.2 \mu \mathrm{g} / \mathrm{L}$ in USGS 97 to $33.9 \mu \mathrm{g} / \mathrm{L}$ in NRF-13.

Mercury.-Concentrations of mercury were not detected in most samples.

Nickel.--Estimated mean concentrations ranged from $1.9 \mu \mathrm{g} / \mathrm{L}$ in USGS 98 to $35 \mu \mathrm{g} / \mathrm{L}$ in NRF-12.

Selenium.-The estimated mean concentration of selenium in five samples from NRF-11 was $2.7 \mu \mathrm{g} / \mathrm{L}$; however, selenium concentrations were not detected in samples from most wells.

Silver.-Concentrations of silver were not detected in most samples.

Thallium.-Concentrations of thallium were not detected in most of the samples.

Zinc.-The estimated mean concentration of zinc in seven samples from USGS 98 was $154 \mu \mathrm{g} / \mathrm{L}$; however, zinc concentrations were not detected in samples from most wells.
Most of the trace elements in the field blanks were not detected or had estimated concentrations below the respective reporting limits. Exceptions include: QAS-54 (blank at USGS 12) has a manganese concentration of $0.21 \mu \mathrm{g} / \mathrm{L}$; QAS-57 (blank at USGS 97) has a barium concentration of $1.3 \mu \mathrm{g} / \mathrm{L}$; copper, $2.3 \mu \mathrm{g} / \mathrm{L}$; manganese, $0.87 \mu \mathrm{g} / \mathrm{L}$; nickel, $0.29 \mu \mathrm{g} / \mathrm{L}$; and zinc, $11 \mu \mathrm{g} / \mathrm{L}$; QAS-60 (blank at USGS 98) has a barium concentration of $1.4 \mu \mathrm{g} / \mathrm{L}$; copper, $2.5 \mu \mathrm{g} / \mathrm{L}$; manganese, $1.1 \mu \mathrm{g} / \mathrm{L}$; nickel, $0.32 \mu \mathrm{g} / \mathrm{L}$; and zinc, $13 \mu \mathrm{g} / \mathrm{L}$. QAS-55 (blank at USGS 99) has a manganese concentration of $0.48 \mu \mathrm{g} / \mathrm{L}$.

\section{Dissolved and Total Nutrients}

Water samples were analyzed for dissolved concentrations of nitrite as nitrogen (table 7). Water samples were analyzed for total concentrations of kjeldahl nitrogen (TKN), nitrite plus nitrate as nitrogen, and phosphorus as phosphorus (table 7); statistical parameters for selected nutrients are provided by well in table 8 and were calculated using the data presented in this report.

Kjeldahl nitrogen.-Concentrations ranged from not detected in most samples to an estimated mean concentration of $0.33 \mathrm{mg} / \mathrm{L}$ in NRF- 12 .

Nitrite as nitrogen.-Concentrations ranged from not detected in most samples to an estimated mean concentration of $0.007 \mathrm{mg} / \mathrm{L}$ in NRF-13.

Nitrite plus nitrate as nitrogen.-Mean concentrations ranged from $0.54 \mathrm{mg} / \mathrm{L}$ in NRF-7 to 2.3 $\mathrm{mg} / \mathrm{L}$ in NRF-9 and USGS 97.

Phosphorus as phosphorus.-Mean concentrations ranged from an estimated $0.048 \mathrm{mg} / \mathrm{L}$ in USGS 99 to $0.15 \mathrm{mg} / \mathrm{L}$ in NRF-13.

Concentrations of constituents in the blank samples were less than the reporting limits except for two samples of nitrite plus nitrate, QAS-54 (blank at USGS 12) contained $0.21 \mathrm{mg} / \mathrm{L}$ and QAS-55 (blank at USGS 99) contained $0.12 \mathrm{mg} / \mathrm{L}$. Several of the blanks contained estimated concentrations of selected nutrients (table 7). 


\section{Total Organic Carbon and Total Organic Halogens}

Water samples were analyzed for concentrations of TOC and total organic halogens (TOX) (table 7). The statistical parameters are provided by well in table 8 and were calculated using data in this report.

Concentrations of TOC ranged from not detected in most samples to an estimated mean concentration of $1.1 \mathrm{mg} / \mathrm{L}$ in USGS 97 . Concentrations of TOX ranged from not detected in most samples to an estimated mean concentration of $0.064 \mathrm{mg} / \mathrm{L}$ in NRF-8. The estimated concentration of TOC in blank sample QAS-54 (blank at USGS 12) was $0.36 \mathrm{mg} / \mathrm{L}$. Blank sample QAS-66 (blank at USGS 99) contained $0.094 \mathrm{mg} / \mathrm{L}$ TOX. Concentrations in all other blank samples were not detected.

\section{Gross Alpha- and Gross Beta-Particle Radioactivity}

Water samples were analyzed for concentrations of dissolved gross alpha- and gross betaparticle radioactivity by the Quanterra laboratory in Richland, WA through a contract with the NWQL using a residue procedure. Concentrations of radioactive constituents greater than or equal to 3 times the 1s uncertainty are considered to be above the reporting level in this report. All analytical measurements are listed in table 9. For a more detailed discussion of reporting levels for radioactive constituents and measurements, see the section of this report titled "Guidelines for Interpreting Results of Radiochemical Analyses."

\section{Gross alpha-particle radioactivity.-Gross} alpha-particle radioactivity is a measure of the total radioactivity given off as alpha particles during the radioactive decay process. For convenience, laboratories report the radioactivity as if it all were given off by one radionuclide. In this report, concentrations are reported as thorium-230 in picocuries per liter. Concentrations of dissolved gross alpha-particle radioactivity are listed in table 9. Statistical parameters are provided by well in table 10 and were calculated using the data presented in this report.
Mean concentrations of gross alpha-particle radioactivity as thorium-230 ranged from $1.42 \pm 0.1$ $\mathrm{pCi} / \mathrm{L}$ in NRF-7 to $4.23 \pm 0.82 \mathrm{pCi} / \mathrm{L}$ in NRF-6. All the field blank samples had concentrations less than the reporting level.

Gross beta-particle radioactivity.-Gross betaparticle radioactivity is a measure of the total radioactivity given off as beta particles during the radioactive decay process. For convenience, laboratories report the radioactivity as if it all were given off by one radionuclide as cesium-137 in picocuries per liter. Concentrations of dissolved gross beta-particle radioactivity are listed in table 9 . Statistical parameters are provided by well in table 10 and were calculated using the data presented in this report.

Mean concentrations of gross beta-particle radioactivity as cesium- 137 ranged from $2.53 \pm 0.26$ $\mathrm{pCi} / \mathrm{L}$ in USGS 99 to $7.21 \pm 0.53 \mathrm{pCi} / \mathrm{L}$ in NRF-6. All the field blank samples had concentrations less than the reporting level.

\section{Strontium-90}

Water samples were analyzed for strontium-90 by chemical separation and beta counting (table 9). Statistical parameters are provided by well in table 10 and were calculated using the data presented in this report. The concentration of strontium- 90 in all the regular and in all field-blank samples were less than the reporting level.

\section{Tritium}

Water samples were analyzed for tritium by enrichment and liquid scintillation (table 9). Statistical parameters are provided by well in table 10 and were calculated using data presented in this report.

Mean concentrations of tritium ranged from $4.12 \pm 0.88 \mathrm{pCi} / \mathrm{L}$ in $\mathrm{NRF}-7$ to $194 \pm 12 \mathrm{pCi} / \mathrm{L}$ in NRF-11. The concentrations of tritium in fieldblank samples ranged from less than the reporting level in two samples to $52.1 \pm 4.9 \mathrm{pCi} / \mathrm{L}$ in QAS-60 (blank for USGS 98). The result for QAS-64 (blank for NRF-8) $(58.0 \pm 5.5 \mathrm{pCi} / \mathrm{L})$ is questionable because of problems with the analysis. 


\section{Selected Gamma-Emitting Radioisotopes}

Gamma spectrometry involves using a series of detectors to simultaneously determine the concentrations of a variety of radionuclides by the detection of their characteristic gamma emissions. Radionuclides identified in selected samples include cesium-137, potassium-40, lead-214, uranium-234, uranium-238, thorium-228, thallium208 , lead-212, radium-224, and radium-226. Concentrations of all the radionuclides identified using gamma spectrometry are given in table 9. Cesium137 was detected in all the samples, so a summary of the statistical parameters for that radionuclide by well is given in table 10 .

All the field-blank samples had concentrations reported as cesium-137 less than the reporting level.

\section{Regulatory Volatile and Base/Neutral Organic Compounds}

Water samples collected in August 1997-98 were analyzed for 59 regulatory volatile compounds (table 11) and 40 base/neutral organic compounds (table 12). Most samples were free of regulatory volatile compounds except for QAS-56, which contained $9.6 \mu \mathrm{g} / \mathrm{L}$ of naphthalene on September 4, 1997, and NRF-6, which contained $0.3 \mu \mathrm{g} / \mathrm{L}$ chloroform, $0.5 \mu \mathrm{g} / \mathrm{L}$ tetrachloroethylene, and $0.1 \mu \mathrm{g} / \mathrm{L}$ 1,1,1-trichloroethane on August 3, 1998. Samples from NRF-8, QAS-55, and USGS 98 contained estimated concentrations of naphthalene during September 1997 at concentrations of $2.6 \mu \mathrm{g} / \mathrm{L}, 0.50 \mu \mathrm{g} / \mathrm{L}$, and $0.96 \mu \mathrm{g} / \mathrm{L}$, respectively. NRF- 6 contained estimated concentrations of $0.27 \mu \mathrm{g} / \mathrm{L}$ of chloroform and $0.47 \mu \mathrm{g} / \mathrm{L}$ of tolulene on September 2, 1997. A field blank (QAS-64) sample of inorganic-free water collected on August 5,1998 , at NRF-8 contained concentrations of $0.5 \mu \mathrm{g} / \mathrm{L}$ dichloromethane, $0.3 \mu \mathrm{g} / \mathrm{L}$ ethylbenzene, 3.6 $\mu \mathrm{g} / \mathrm{L}$ toluene, $0.1 \mu \mathrm{g} / \mathrm{L}$ 1,2,4-trimethylbenzene, and $0.6 \mu \mathrm{g} / \mathrm{L}$ total xylenes. An additional compound, 1,1-dichloropropanene was also detected at. a concentration of $21 \mu \mathrm{g} / \mathrm{L}$. Inorganic-free water was used because there was no organic-free water available at the time of collection. Samples from USGS 12, 97, 99, and 102 collected on September 3, 1997 contained $5.6 \mu \mathrm{g} / \mathrm{L}, 1.5 \mu \mathrm{g} / \mathrm{L}, 4.7 \mu \mathrm{g} / \mathrm{L}$, and
$0.7 \mu \mathrm{g} / \mathrm{L}$ of di (2-ethylhexl) phthalate, respectively. All other samples collected were free of base/neutral organic compounds; one sample, NRF-6, collected on August 3, 1998, contained an additional compound of bromacil at a concentration of $0.3 \mu \mathrm{g} / \mathrm{L}$.

\section{SUMMARY}

The USGS, in response to a request from the U.S. Department of Energy's Pittsburgh Naval Reactors Office, Idaho Branch Office, sampled 13 wells during 1997-98 as part of a long-term project to monitor water quality of the Snake River Plain aquifer in the vicinity of the NRF, INEEL, Idaho. Water samples were collected and analyzed for naturally occurring constituents and man-made contaminants. A total of 91 samples were collected from 13 monitoring wells with dedicated submersible pumps. Fourteen quality-assurance samples also were collected and analyzed; seven field-blank samples and seven replicate samples.

The ranges of mean concentrations of total cations and dissolved anions follow: calcium, 28 to $132 \mathrm{mg} / \mathrm{L}$; chloride, 4.5 to $249 \mathrm{mg} / \mathrm{L}$; magnesium, 9.5 to $34 \mathrm{mg} / \mathrm{L}$; potassium, 1.8 to $5.0 \mathrm{mg} / \mathrm{L}$; sodium, 9.1 to $116 \mathrm{mg} / \mathrm{L}$; and sulfate, 13.6 to 170 $\mathrm{mg} / \mathrm{L}$.

Samples were analyzed for 17 trace elements. Concentrations of aluminum, antimony, arsenic, beryllium, cadmium, copper, lead, mercury, selenium, silver, thallium, and zinc were not detected in most wells. Concentrations of iron ranged from not detected in several wells to a mean concentration of $4,960 \mu \mathrm{g} / \mathrm{L}$. The respective ranges of estimated mean concentrations for barium, chromium, manganese, and nickel were: 50 to $158 \mu \mathrm{g} / \mathrm{L} ; 4.7$ to $66.5 \mu \mathrm{g} / \mathrm{L} ; 1.2$ to $33.9 \mu \mathrm{g} / \mathrm{L}$; and 1.9 to $35 \mu \mathrm{g} / \mathrm{L}$, respectively. The predominant nitrogen-bearing compound was nitrite plus nitrate, which ranged in mean concentration from 0.54 to $2.3 \mathrm{mg} / \mathrm{L}$. Mean concentrations of phosphorus as phosphorus ranged from 0.048 to $0.15 \mathrm{mg} / \mathrm{L}$.

Concentrations of TOC and TOX ranged from not detected in most samples to estimated mean concentrations of 1.1 and $0.064 \mathrm{mg} / \mathrm{L}$, respectively. 
Concentrations of dissolved gross alpha- and gross beta-particle radioactivity and tritium exceeded the reporting level in most samples. Concentrations of strontium- 90 and gross gamma as cesium-137 were less than the reporting level in all samples.

All but two samples were free of regulatory volatile organic compounds. All the samples collected were free of base/neutral organic compounds. Most of the field blank samples contained concentrations of the constituents less than the reporting levels. Select field blank samples contained small concentrations of calcium, magnesium, barium, copper, manganese, nickel, zinc, nitrite plus nitrate, TOX, tritium, and selected volatile organic compounds.

\section{SELECTED REFERENCES}

Ackerman, D.J., 1991, Transmissivity of the Snake River Plain aquifer at the Idaho National Engineering Laboratory, Idaho: U.S. Geological Survey Water-Resources Investigations Report 91-4058 (DOE/ID-22097), 35 p.

American Society for Testing and Materials, 1992, ASTM standards on precision and bias for various applications: Philadelphia, Pa., American Society for Testing and Materials Publication code number (PCN) 03-511092-34, $478 \mathrm{p}$.

American Society for Testing and Materials, 1998, Standard method for high-resolution gammaray spectrometry of water (D3649-91): Philadelphia, Pa., American Society of Testing and Materials 1998 Annual Book of ASTM Standards, v. 11.02, 1,048 p.

Anderson, S.R., Ackerman, D.J., Liszewski, M.J., and Freiburger, R.M., 1996, Stratigraphic data for wells at and near the Idaho National Engineering Laboratory, Idaho: U.S. Geological Survey Open-File Report 96-248 (DOE/ID22127), 27 p., 1 diskette.

Bartholomay, R.C., Knobel, L.L., and Tucker, B.J., 1993, Chemical constituents in water from wells in the vicinity of the Naval Reactors Facility, Idaho National Engineering Labora- tory, Idaho, 1990-91: U.S. Geological Survey Open-File Report 93-94 (DOE/ID-22106), $70 \mathrm{p}$.

1997, Chemical and radiochemical constituents in water from wells in the vicinity of the Naval Reactors Facility, Idaho National Engineering Laboratory, Idaho, 1994-95: U.S. Geological Survey Open-File Report 97-806 (DOE/ID-22143), $70 \mathrm{p}$.

Bartholomay, R.C., Tucker, B.J., Ackerman, D.J., and Liszewski, M.J., 1997, Hydrologic conditions and distribution of selected radiochemical and chemical constituents in water, Snake River Plain aquifer, Idaho National Engineering Laboratory, Idaho, 1992 through 1995: U.S. Water-Resources Investigations Report 97-4086 (DOE/ID-22137), 57 p.

Bettis Atomic Power Laboratory Naval Reactors Facility, 1994, Remedial investigation/feasibility study for the external industrial waste ditch, operable unit 8-07: Westinghouse Electric Corporation NRFRC-EC-1046, 26 p.

--.-- 1997, Final NRF comprehensive remedial investigation/feasibility study, waste area group 8, Naval Reactors Facility, Idaho Falls, Idaho: Westinghouse Electric Corporation [variously paged].

Claassen, H.C., 1982, Guidelines and techniques for obtaining water samples that accurately represent the water chemistry of an aquifer: U.S. Geological Survey Open-File Report 82-1024, 49 p.

Currie, L.A., 1984, Lower limit of detection-Definition and elaboration of a proposed position for radiological effluent and environmental measurements: U.S. Nuclear Regulatory Commission NUREG/CR-4077, 139 p.

Hardy, M.A., Leahy, P.P., and Alley, W.M., 1989, Well installation and documentation, and ground-water sampling protocols for the pilot national water-quality assessment program: U.S. Geological Survey Open-File Report 89396, $36 \mathrm{p}$.

Iman, R.L., and Conover, W.J., 1983, A modern approach to statistics: New York, John Wiley \& Sons, Inc., $497 \mathrm{p}$. 
Knobel, L.L., Bartholomay, R.C., Tucker, B.J., and Williams, L.M., 1999, Chemical and radiochemical constituents in water from wells in the vicinity of the Naval Reactors Facility, Idaho National Engineering and Environmental Laboratory, Idaho, 1996: U.S. Geological Survey Open-File Report 99-272 (DOE/LD22160), 58 p.

Knobel, L.L., Bartholomay, R.C., Wegner, S.J., and Edwards, D.D., 1992, Chemical constituents in water from wells in the vicinity of the Naval Reactors Facility, Idaho National Engineering Laboratory, Idaho, 1989-90: U.S. Geological Survey Open-File Report 92-156 (DOE/ID-22103), 38 p.

Knobel, L.L., Orr, B.R., and Cecil, L.D., 1992, Summary of background concentrations of selected radiochemical and chemical constituents in groundwater from the Snake River Plain aquifer, Idaho; estimated from an analysis of previously published data: Journal of the Idaho Academy of Science, v. 28, no. 1 , p. 48-61.

Mann, L.J., 1986, Hydraulic properties of rock units and chemical quality of water for INEL1-a 10,365-foot deep test hole drilled at the Idaho National Engineering Laboratory, Idaho: U.S. Geological Survey WaterResources Investigations Report 86-4020 (DOE/ID-22070), 23 p.

-..-- 1989, Tritium concentrations in flow from selected springs that discharge to the Snake River, Twin Falls-Hagerman area, Idaho: U.S. Geological Survey Water-Resources Investigations Report 89-4156 (DOE/ID-22084), $20 \mathrm{p}$.

-..- 1996, Quality-assurance plan and field methods for quality-of-water activities, U.S. Geological Survey, Idaho National Engineering Laboratory, Idaho: U.S. Geological Survey Open-File Report 96-615 (DOE/ID-22132), $37 \mathrm{p}$.

Olmstead, F.H., 1962, Chemical and physical character of ground water in the National Reactor Testing Station, Idaho: U.S. Atomic Energy Commission Publication IDO-22043, 81 p.
Orr, B.R., and Cecil, L.D., 1991, Hydrologic conditions and distribution of selected chemical constituents in water, Snake River Plain aquifer, Idaho National Engineering Laboratory, Idaho, 1986 to 1988: U.S. Geological Survey Water-Resources Investigations Report 91-4047 (DOE/ID-22096), 56 p.

Quanterra Environmental Services, 1998, Quality Assurance Management Plan for environmental services; revision 3: Quanterra Environmental Services, [variously paged].

Stevens, H.H., Jr., Ficke, J.F., and Smoot, G.F., 1975, Water temperature-influential factors, field measurement, and data presentation: U.S. Geological Survey Techniques of WaterResources Investigations, book 5, chap. D1, $65 \mathrm{p}$.

Thatcher, L.L., Janzer, V.J., and Edwards, K.W., 1977 , Methods for determination of radioactive substances in water and fluvial sediments: U.S. Geological Survey Techniques of WaterResources Investigations, book 5, chap. A5, $95 \mathrm{p}$.

Tucker, B.J., Knobel, L.L., and Bartholomay, R.C., 1995, Chemical constituents in water from wells in the vicinity of the Naval Reactors Facility, Idaho National Engineering Laboratory, Idaho, 1991-93: U.S. Geological Survey Open-File Report 95-725 (DOE/ID-22125), $94 \mathrm{p}$.

U.S. Environmental Protection Agency, 1989, Protection of Environment, Code of Federal Regulations 40: Office of the Federal Register, National Archives and Records Administration, pts. 190 to $299,1,027$ p.

U.S. Geological Survey, 1985, National water summary, 1984-Hydrologic events, selected water-quality trends, and ground-water resources: U.S. Geological Survey WaterSupply Paper 2275, 467 p.

Wegner, S.J., 1989, Selected water quality assurance data for water samples collected by the U.S. Geological Survey, Idaho National Engineering Laboratory, Idaho, 1980 to 1988: U.S. 
Geological Survey Water-Resources Investigations Report 89-4168 (DOE/ID-22085), $91 \mathrm{p}$.

Wilde, F.D., Radtke, D.B., Gibs, J., and Iwatsubo, R.T., 1998, National field manual for the collection of water-quality data: U.S. Geological Survey Techniques of Water-Resources Investigations, book 9, variously paged.

Williams, L.M., 1996, Evaluation of quality assurance/quality control data collected by the U.S. Geological Survey for water-quality activities at the Idaho National Engineering Laboratory, Idaho, 1989 through 1993: U.S. Geological
Survey Water-Resources Investigations Report 96-4148 (DOE/ID-22129), 116 p.

----- 1997, Evaluation of quality assurance/quality control data collected by the U.S. Geological Survey for water-quality activities at the Idaho National Engineering Laboratory, Idaho, 1994 through 1995: U.S. Geological Survey WaterResources Investigations Report 97-4058 (DOE/ID-22136), 87 p.

Wood, W.W., 1981, Guidelines for collection and field analysis of ground-water samples for selected unstable constituents: U.S. Geological Survey Techniques of Water-Resources Investigations, book 1 , chap. D2, $24 \mathrm{p}$. 
Table 1. Containers and preservatives used for water samples, Naval Reactors Facility and vicinity [Analyses by Quanterra Environmental Services Laboratory. Abbreviations: $\mathrm{L}$, liter; mL, milliliter; $\mathrm{HNO}_{3}$, nitric acid; $\mathrm{H}_{2} \mathrm{SO}_{4}$, sulfuric acid; $\mathrm{HCL}$, hydrochloric acid; ${ }^{\circ} \mathrm{C}$, degrees Celsius. Samples were shipped by overnight-delivery mail]

\begin{tabular}{|c|c|c|c|c|c|}
\hline \multirow[b]{2}{*}{ Type of constituent } & \multicolumn{2}{|c|}{ Container } & \multicolumn{2}{|c|}{ Preservative } & \multirow{2}{*}{$\begin{array}{c}\text { Other } \\
\text { treatment }\end{array}$} \\
\hline & Type & Size & Type & Volume & \\
\hline Anions & Polyethylene & $1 \mathrm{~L}$ & None & None & Filter \\
\hline Cations, total recoverable & Polyethylene & $500 \mathrm{~mL}$ & $\mathrm{HNO}_{3}$ & $10 \mathrm{~mL}$ & None \\
\hline Trace elements, total recoverable & Polyethylene & $500 \mathrm{~mL}$ & $\mathrm{HNO}_{3}$ & $10 \mathrm{~mL}$ & None \\
\hline Nitrite & Polyethylene & $1 \mathrm{~L}$ & None & None & Filter \\
\hline Nutrients, total recoverable & Glass, baked & $500 \mathrm{~mL}$ & $\mathrm{H}_{2} \mathrm{SO}_{4}$ & $2 \mathrm{~mL}$ & Chill $4^{\circ} \mathrm{C}$ \\
\hline Specific conductance & Polyethylene & $1 \mathrm{~L}$ & None & None & Filter \\
\hline Total organic carbon & Glass, baked & $500 \mathrm{~mL}$ & $\mathrm{H}_{2} \mathrm{SO}_{4}$ & $2 \mathrm{~mL}$ & Chill $4^{\circ} \mathrm{C}$ \\
\hline Total organic halogens & Glass, baked & $250 \mathrm{~mL}$ & $\mathrm{H}_{2} \mathrm{SO}_{4}$ & $1 \mathrm{~mL}$ & Chill $4^{\circ} \mathrm{C}$ \\
\hline Purgeable organic compounds & Glass, baked & $40 \mathrm{~mL}$ & HCL & 4 drops & Chill $4^{\circ} \mathrm{C}$ \\
\hline $\begin{array}{l}\text { Semi-volatile organic } \\
\text { compounds }\end{array}$ & Glass, baked & $1 \mathrm{~L}$ & None & None & Chill $4^{\circ} \mathrm{C}$ \\
\hline Gamma & $\begin{array}{l}\text { Polyethylene, } \\
\text { acid-rinsed }\end{array}$ & $1 \mathrm{~L}$ & $\mathrm{HNO}_{3}$ & $20 \mathrm{~mL}$ & Filter \\
\hline $\begin{array}{l}\text { Gross alpha- and beta-particle } \\
\text { radioactivity }\end{array}$ & $\begin{array}{l}\text { Polyethylene, } \\
\text { acid-rinsed }\end{array}$ & $1 \mathrm{~L}$ & $\mathrm{HNO}_{3}$ & $20 \mathrm{~mL}$ & Filter \\
\hline Strontium-90 & $\begin{array}{l}\text { Polyethylene, } \\
\text { acid-rinsed }\end{array}$ & $1 \mathrm{~L}$ & $\mathrm{HNO}_{3}$ & $20 \mathrm{~mL}$ & Filter \\
\hline Tritium & $\begin{array}{l}\text { Polyethylene or } \\
\text { glass, baked }\end{array}$ & $500 \mathrm{~mL}$ & None & None & None \\
\hline
\end{tabular}




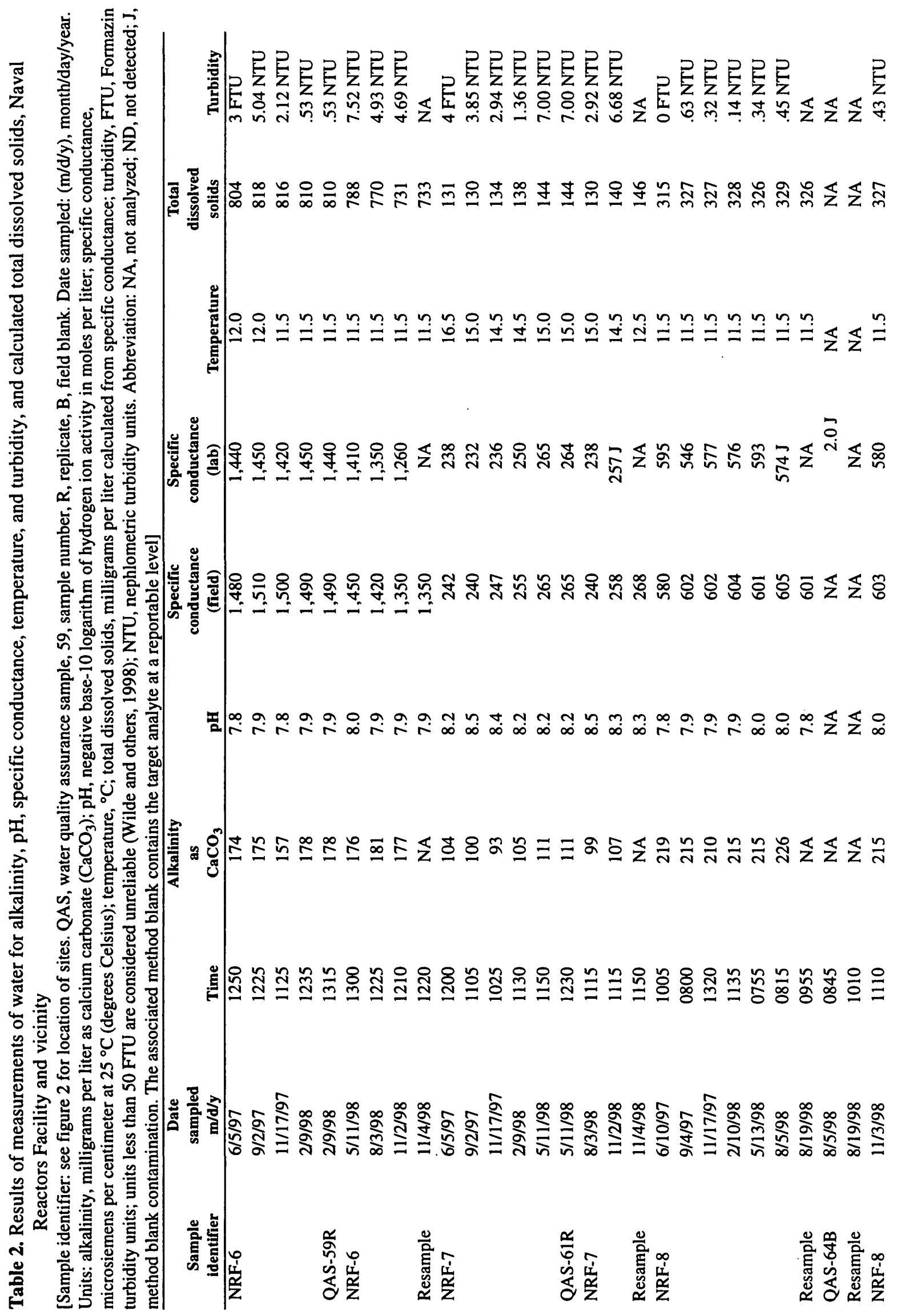




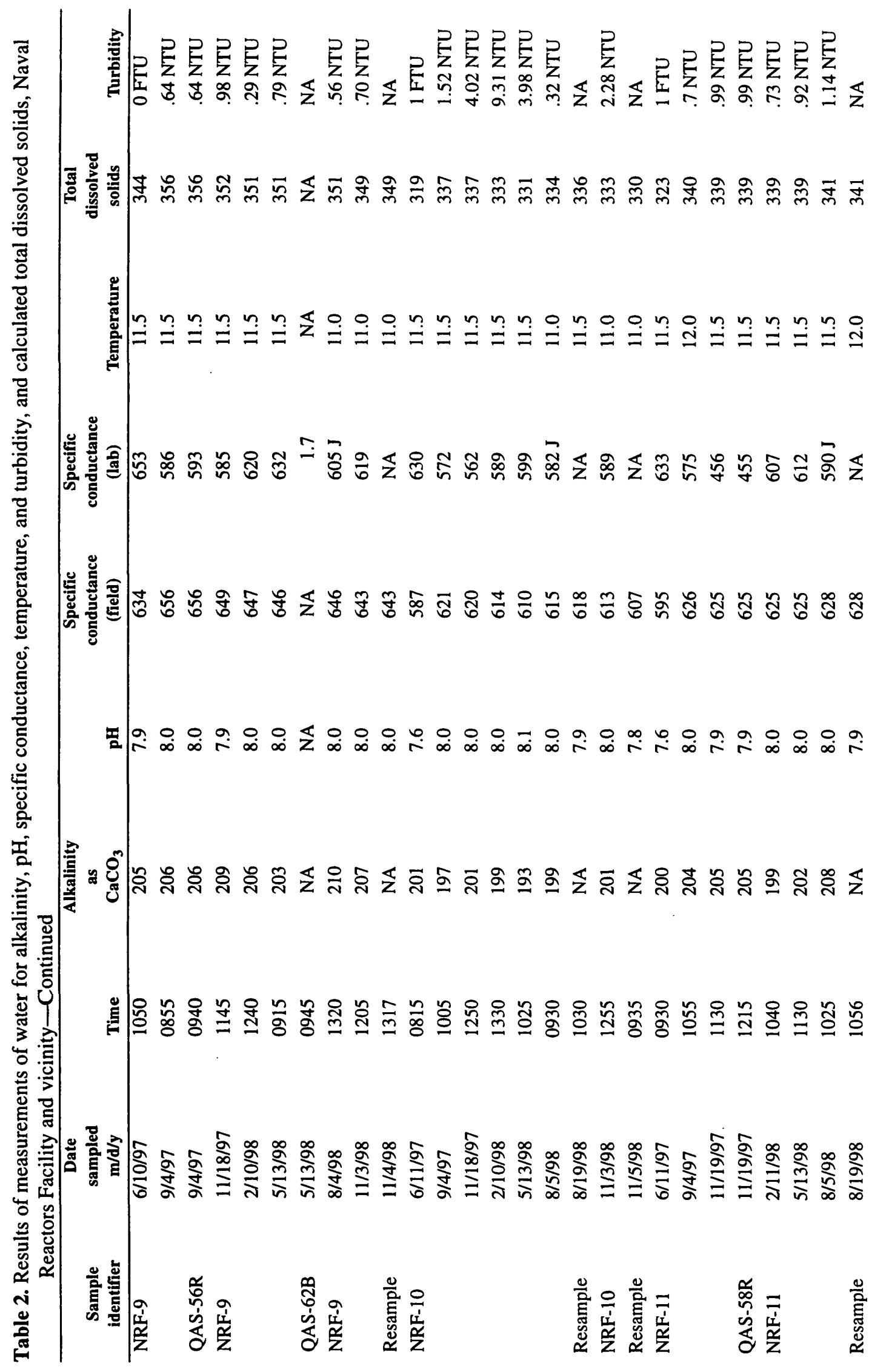




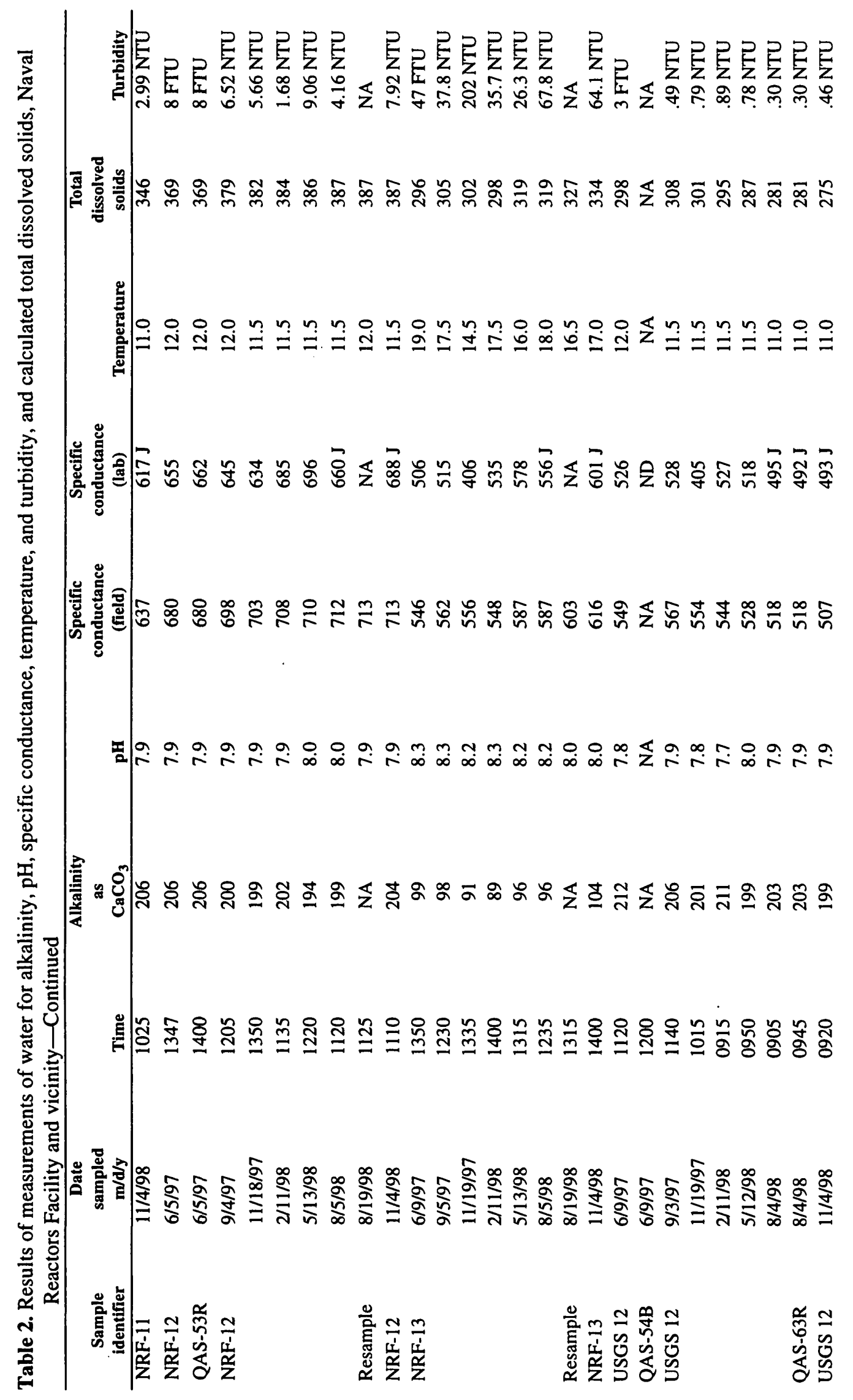




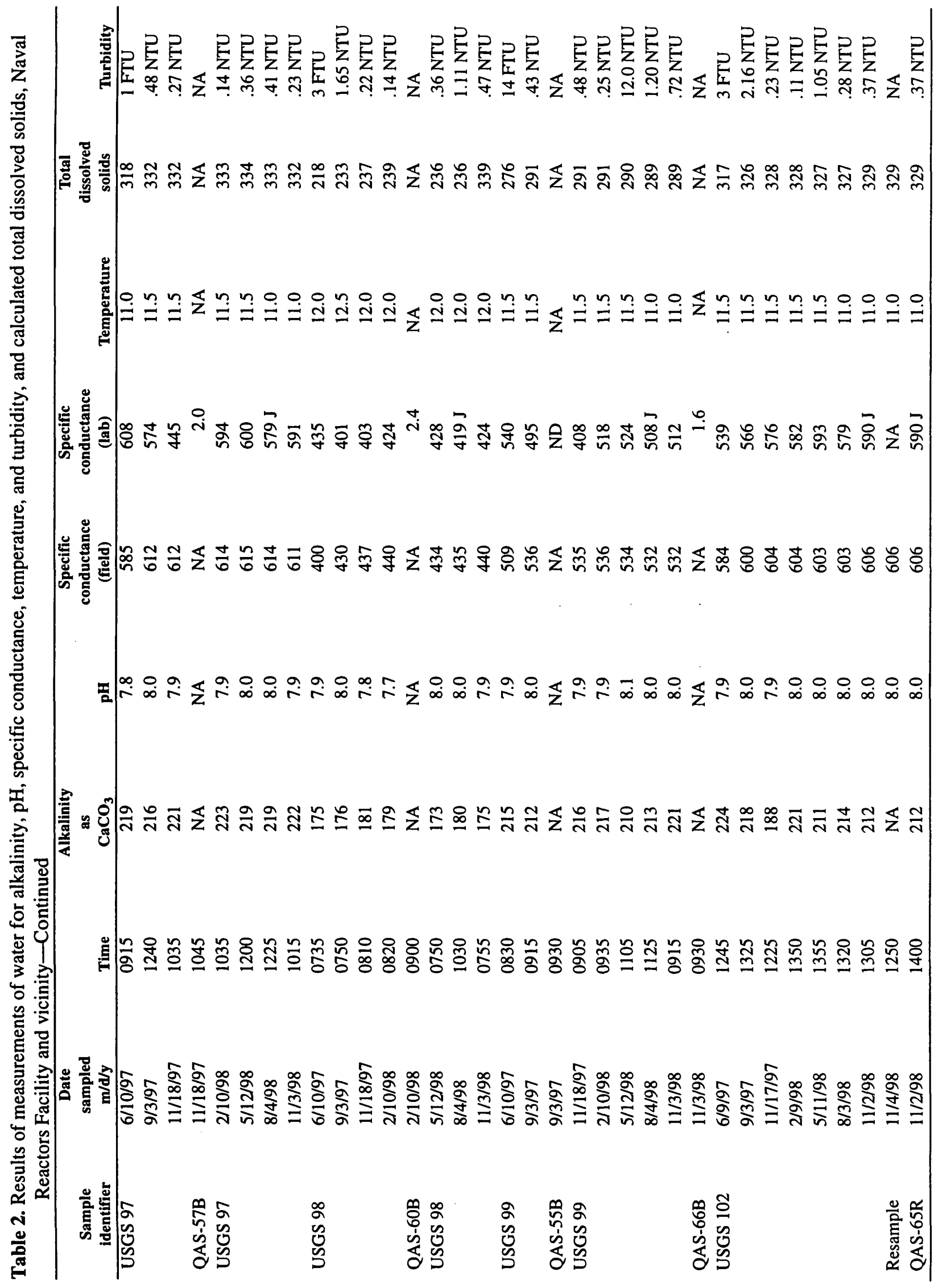


Table 3. Concentrations of dissolved anions and total cations in water, Naval Reactors Facility and vicinity

[Analyses were performed by Quanterra Environmental Services Laboratory. Analytical results in milligrams per liter. Sample identifier: see figure 2 for location of sites. QAS, water quality assurance sample; 59 , sample number; R, replicate; B, field blank. Date sampled: $(\mathrm{m} / \mathrm{d} / \mathrm{y})$, month/day/year. ND, analysis not detected; *, estimated result; $\mathrm{S}$, sample diluted due to concentration of target compounds; Q, reporting limit is elevated due to high analyte levels]

\begin{tabular}{|c|c|c|c|c|c|c|c|}
\hline $\begin{array}{l}\text { Sample } \\
\text { identifier }\end{array}$ & $\begin{array}{l}\text { Date sampled } \\
\mathrm{m} / \mathrm{d} / \mathrm{y}\end{array}$ & $\begin{array}{c}\text { Calcium } \\
\text { (total) }\end{array}$ & $\begin{array}{c}\text { Chloride } \\
\text { (dissolved) }\end{array}$ & $\begin{array}{l}\text { Magnesium } \\
\text { (total) }\end{array}$ & $\begin{array}{c}\text { Potassium } \\
\text { (total) }\end{array}$ & $\begin{array}{c}\text { Sodium } \\
\text { (total) }\end{array}$ & $\begin{array}{c}\text { Sulfate } \\
\text { (dissolved) }\end{array}$ \\
\hline \multirow{4}{*}{ NRF-6 } & $6 / 5 / 97$ & 134 & $267 \mathrm{~S}$ & 34.4 & 5.0 & 122 & $194 \mathrm{~S}$ \\
\hline & $9 / 2 / 97$ & 141 & $257 \mathrm{~S}$ & 35.9 & 5.7 & 124 & $191 \mathrm{~S}$ \\
\hline & $11 / 17 / 97$ & .128 & $251 \mathrm{~S}$ & 33 & 5.0 & 115 & $182 \mathrm{~S}$ \\
\hline & $2 / 9 / 98$ & 132 & $261 \mathrm{~S}$ & 33.7 & 5.3 & 118 & $165 \mathrm{~S}$ \\
\hline QAS-59R & 2/9/98 & 132 & $258 \mathrm{~S}$ & 34.0 & 5.3 & 118 & $166 S$ \\
\hline \multirow[t]{3}{*}{ NRF-6 } & $5 / 11 / 98$ & 137 & $245 Q$ & 34.2 & 5.0 & 119 & $156 \mathrm{Q}$ \\
\hline & $8 / 3 / 98$ & 125 & $243 \mathrm{Q}$ & 33.4 & $4.53^{*}$ & 113 & $159 \mathrm{Q}$ \\
\hline & $11 / 2 / 98$ & 124 & $209 \mathrm{Q}$ & 32.1 & $4.5^{*}$ & 100 & $145 \mathrm{Q}$ \\
\hline \multirow[t]{5}{*}{ NRF-7 } & $6 / 5 / 97$ & 26.9 & 4.7 & 8.9 & $2.9^{*}$ & 9.1 & 13.5 \\
\hline & $9 / 2 / 97$ & 26.6 & 4.6 & 9.1 & $2.9^{*}$ & 8.3 & 13.7 \\
\hline & $11 / 17 / 97$ & 27.2 & 4.0 & 9.5 & $3.3^{*}$ & 9.5 & 13.8 \\
\hline & $2 / 9 / 98$ & 28.7 & 4.5 & 9.6 & $3.3^{*}$ & 9.0 & 13.4 \\
\hline & $5 / 11 / 98$ & 31.5 & 4.3 & 9.5 & $3.1^{*}$ & 9.7 & 13.6 \\
\hline QAS-61R & $5 / 11 / 98$ & 31.9 & 4.3 & 9.6 & $3.2^{*}$ & 9.9 & 13.5 \\
\hline \multirow[t]{2}{*}{ NRF-7 } & $8 / 3 / 98$ & 24.1 & 4.8 & 9.39 & $2.72 *$ & 8.27 & 13.9 \\
\hline & $11 / 2 / 98$ & 30.4 & 4.9 & 10.1 & $2.8^{*}$ & 9.4 & 13.1 \\
\hline \multirow[t]{6}{*}{ NRF-8 } & $6 / 10 / 97$ & 76.0 & 39.3 & 24.5 & $2.4^{*}$ & 16.3 & 37.3 \\
\hline & 9/4/97 & 73.0 . & 35.1 & 24.6 & $2.2^{*}$ & 14.8 & 34.8 \\
\hline & $11 / 17 / 97$ & 73.0 & 35.5 & 23.5 & $2.5^{*}$ & 15.1 & 36.7 \\
\hline & $2 / 10 / 98$ & 75.5 & 36.1 & 24.1 & $2.6^{*}$ & 15.1 & 35.9 \\
\hline & $5 / 13 / 98$ & 75.2 & 36.2 & 23.3 & $2.3^{*}$ & 15.0 & 36.2 \\
\hline & $8 / 5 / 98$ & 70.3 & 36.6 & 23.4 & $2.29 *$ & 15.2 & 37.5 \\
\hline QAS-64B & $8 / 5 / 98$ & ND & ND & ND & ND & ND & ND \\
\hline NRF-8 & $11 / 3 / 98$ & 76.3 & 35.7 & 24.4 & $2.2^{*}$ & 15.1 & 34.8 \\
\hline \multirow[t]{2}{*}{ NRF-9 } & $6 / 10 / 97$ & 79.5 & 51.0 & 25.0 & $2.6^{*}$ & 19.6 & 48.5 \\
\hline & 9/4/97 & 78.1 & 46.8 & 25.2 & $2.5^{*}$ & 18.2 & 46.9 \\
\hline QAS-56R & 9/4/97 & 74.3 & 46.9 & 25.2 & $2.5^{*}$ & 15.0 & 46.7 \\
\hline \multirow[t]{3}{*}{ NRF-9 } & $11 / 18 / 97$ & 76.6 & 47.5 & 23.9 & $2.8^{*}$ & 18.4 & 48.3 \\
\hline & $2 / 10 / 98$ & 79.7 & 47.1 & 24.5 & $2.8^{*}$ & 18.2 & 46.8 \\
\hline & $5 / 13 / 98$ & 80.2 & 47.9 & 24.5 & $2.6^{*}$ & 19.7 & 46.8 \\
\hline QAS-62B & $5 / 13 / 98$ & $.061^{*}$ & ND & ND & ND & ND & ND \\
\hline \multirow[t]{2}{*}{ NRF-9 } & $8 / 4 / 98$ & 72.2 & $44.4 \mathrm{Q}$ & 23.3 & $2.59 *$ & 18.8 & 46.9 \\
\hline & $11 / 3 / 98$ & 79.8 & 45.7 & 24.6 & $2.2 *$ & 18.0 & 44.1 \\
\hline \multirow[t]{7}{*}{ NRF-10 } & $6 / 11 / 97$ & 76.1 & 47.1 & 24.7 & $2.6^{*}$ & 16.8 & 45.8 \\
\hline & $9 / 4 / 97$ & 77.6 & 44.0 & 25.1 & $2.5^{*}$ & 18.9 & 43.3 \\
\hline & $11 / 18 / 97$ & 72.7 & 45.5 & 23.3 & $2.8^{*}$ & 15.5 & 45.2 \\
\hline & $2 / 10 / 98$ & 75.6 & 44.7 & 24.6 & $3.1^{*}$ & 15.8 & 43.7 \\
\hline & $5 / 13 / 98$ & 76.9 & 44.7 & 23.5 & $2.6^{*}$ & 15.8 & 43.7 \\
\hline & $8 / 5 / 98$ & 69.2 & 44.4 & 23.1 & $2.29 *$ & 15.2 & 44.5 \\
\hline & $11 / 3 / 98$ & 75.5 & 42.5 & 24.2 & $2.2^{*}$ & 16.0 & 40.7 \\
\hline \multirow[t]{3}{*}{ NRF-11 } & $6 / 11 / 97$ & 75.1 & 48.0 & 24.0 & $2.8^{*}$ & 20.5 & 49.1 \\
\hline & $9 / 4 / 97$ & 73.9 & 42.9 & 24.8 & $2.6^{*}$ & 18.4 & 43.8 \\
\hline & $11 / 19 / 97$ & 74.4 & 43.1 & 23.2 & $2.7^{*}$ & 18.3 & 44.7 \\
\hline QAS-58R & $11 / 19 / 97$ & 73.6 & 43.3 & 23.2 & $2.6^{*}$ & 17.9 & 44.5 \\
\hline \multirow[t]{4}{*}{ NRF-11 } & $2 / 11 / 98$ & 74.5 & 44.4 & 23.9 & $2.8^{*}$ & 17.6 & 43.5 \\
\hline & $5 / 13 / 98$ & 80.3 & 43.3 & 24.1 & $2.7^{*}$ & 18.7 & 43.2 \\
\hline & $8 / 5 / 98$ & 69.5 & 45.2 & 22.9 & $2.28 *$ & 17.8 & 44.6 \\
\hline & $11 / 4 / 98$ & 71.3 & 44.1 & 22.9 & $2.5^{*}$ & 17.6 & 41.4 \\
\hline
\end{tabular}


Table 3. Concentrations of dissolved anions and total cations in water, Naval Reactors Facility and vicinityContinued

\begin{tabular}{|c|c|c|c|c|c|c|c|}
\hline $\begin{array}{c}\text { Sample } \\
\text { identifier }\end{array}$ & $\begin{array}{c}\text { Date sampled } \\
\mathrm{m} / \mathrm{d} / \mathrm{y}\end{array}$ & $\begin{array}{c}\text { Calcium } \\
\text { (total) }\end{array}$ & $\begin{array}{c}\text { Chloride } \\
\text { (dissolved) }\end{array}$ & $\begin{array}{l}\text { Magnesium } \\
\text { (total) }\end{array}$ & $\begin{array}{c}\text { Potassium } \\
\text { (total) }\end{array}$ & $\begin{array}{c}\text { Sodium } \\
\text { (total) }\end{array}$ & $\begin{array}{c}\text { Sulfate } \\
\text { (dissolved) }\end{array}$ \\
\hline NRF-12 & $6 / 5 / 97$ & 80.1 & 61.6 & 24.5 & $2.6^{*}$ & 22.4 & 60.3 \\
\hline QAS-53R & $6 / 5 / 97$ & 81.1 & 61.8 & 25.0 & $2.7^{*}$ & 22.2 & 59.5 \\
\hline \multirow[t]{6}{*}{ NRF-12 } & 9/4/97 & 80.5 & 60.0 & 26.3 & $2.7^{*}$ & 23.2 & 57.5 \\
\hline & $11 / 18 / 97$ & 80.8 & 61.6 & 24.7 & $2.9^{*}$ & 22.9 & 60.5 \\
\hline & $2 / 11 / 98$ & 82.0 & 64.4 & 25.7 & $3.0^{*}$ & 23.5 & 60.3 \\
\hline & $5 / 13 / 98$ & 82.3 & 64.0 & 24.5 & $2.6^{*}$ & 23.9 & 59.8 \\
\hline & $8 / 5 / 98$ & 77.6 & 64.6 & 25.0 & $2.94 *$ & 25.7 & 60.9 \\
\hline & $11 / 4 / 98$ & 76.5 & $60.9 \mathrm{Q}$ & 24.1 & $2.7^{*}$ & 24.1 & $52.4 \mathrm{Q}$ \\
\hline \multirow[t]{7}{*}{ NRF-13 } & 6/9/97 & 75.6 & 66.7 & 21.2 & $4.8^{*}$ & 12.2 & 76.1 \\
\hline & $9 / 5 / 97$ & 103 & 63.3 & 32.6 & $4.9 *$ & 14.1 & 74.8 \\
\hline & $11 / 19 / 97$ & 74.1 & 65.3 & 20.2 & $4.7^{*}$ & 11.4 & 78.8 \\
\hline & $2 / 11 / 98$ & 61.8 & 65.2 & 16.9 & $4.2^{*}$ & 10.7 & 78.6 \\
\hline & $5 / 13 / 98$ & 73.3 & 68.0 & 20.0 & $4.0^{*}$ & 10.9 & 83.1 \\
\hline & $8 / 5 / 98$ & 71.2 & 69.4 & 20.7 & $4.0^{*}$ & 10.9 & 85.8 \\
\hline & $11 / 4 / 98$ & 71.9 & $69.1 \mathrm{Q}$ & 21.9 & $4.1^{*}$ & 11.2 & $82.0 \mathrm{Q}$ \\
\hline USGS 12 & $6 / 9 / 97$ & 70.9 & 36.3 & 22.7 & $2.2^{*}$ & 17.7 & 35.4 \\
\hline QAS-54B & $6 / 9 / 97$ & ND & ND & ND & ND & ND & ND \\
\hline \multirow[t]{5}{*}{ USGS 12} & $9 / 3 / 97$ & 67.8 & 32.0 & 22.6 & $2.0^{*}$ & 16.7 & 32.1 \\
\hline & $11 / 19 / 97$ & 66.2 & 29.5 & 20.9 & $2.2^{*}$ & 16.5 & 31.5 \\
\hline & $2 / 11 / 98$ & 66.1 & 28.2 & 21.1 & $2.3^{*}$ & 16.4 & 30.1 \\
\hline & $5 / 12 / 98$ & 65.1 & 25.0 & 19.7 & $2.1^{*}$ & 16.1 & 28.4 \\
\hline & $8 / 4 / 98$ & 59.0 & 24.2 & 19.4 & $1.83^{*}$ & 15.2 & 28.2 \\
\hline QAS-63R & $8 / 4 / 98$ & 58.9 & 26.9 & 19.5 & $1.8^{*}$ & 15.0 & 28.7 \\
\hline USGS 12 & $11 / 4 / 98$ & 57.4 & 19.6 & 18.6 & $1.8^{*}$ & 14.5 & 25.0 \\
\hline \multirow[t]{3}{*}{ USGS 97} & $6 / 10 / 97$ & 74.6 & 38.1 & 24.3 & $2.2^{*}$ & 16.4 & 36.2 \\
\hline & $9 / 3 / 97$ & 76.5 & 35.5 & 24.1 & $2.4^{*}$ & 15.9 & 36.6 \\
\hline & $11 / 18 / 97$ & 73.1 & 36.0 & 23.6 & $2.4^{*}$ & 15.6 & 36.2 \\
\hline QAS-57B & $11 / 18 / 97$ & ND & ND & ND & ND & ND & ND \\
\hline \multirow[t]{4}{*}{ USGS 97} & $2 / 10 / 98$ & 74.8 & 36.5 & 24.7 & $2.2^{*}$ & 15.6 & 35.9 \\
\hline & $5 / 12 / 98$ & 73.4 & 36.2 & 23.5 & $2.2^{*}$ & 15.9 & 35.8 \\
\hline & $8 / 4 / 98$ & 70.3 & 39.4 & 23.9 & $2.09 *$ & 16.2 & 36.7 \\
\hline & $11 / 3 / 98$ & 77.1 & 36.1 & 25.2 & $2.0^{*}$ & 16.0 & 34.8 \\
\hline \multirow[t]{4}{*}{ USGS 98} & $6 / 10 / 97$ & 51.3 & 14.6 & 19.7 & $2.2^{*}$ & 10.4 & 21.6 \\
\hline & $9 / 3 / 97$ & 50.4 & 15.1 & 20.1 & $2.0^{*}$ & 10.1 & 22.0 \\
\hline & $11 / 18 / 97$ & 51.4 & 13.9 & 19.4 & $2.3^{*}$ & 9.7 & 22.2 \\
\hline & $2 / 10 / 98$ & 53.0 & 14.7 & 20.1 & $2.2^{*}$ & 9.4 & 21.8 \\
\hline QAS-60B & $2 / 10 / 98$ & ND & ND & ND & ND & ND & ND \\
\hline \multirow[t]{3}{*}{ USGS 98} & $5 / 12 / 98$ & 49.8 & 14.2 & 18.3 & $2.0^{*}$ & 9.6 & 21.7 \\
\hline & $8 / 4 / 98$ & 48.0 & 14.6 & 18.8 & $2.03^{*}$ & 9.68 & 21.9 \\
\hline & $11 / 3 / 98$ & 52.8 & 13.9 & 20.1 & $1.8^{*}$ & 9.3 & 21.0 \\
\hline \multirow[t]{2}{*}{ USGS 99} & $6 / 10 / 97$ & 65.6 & 23.0 & 22.9 & $1.9^{*}$ & 15.8 & 26.0 \\
\hline & $9 / 3 / 97$ & 63.7 & 21.4 & 23.2 & $1.8^{*}$ & 15.1 & 25.9 \\
\hline QAS-55B & $9 / 3 / 97$ & .63 & ND & .21 & ND & ND & ND \\
\hline \multirow[t]{5}{*}{ USGS 99} & $11 / 18 / 97$ & 63.5 & 21.1 & 21.8 & $2.0^{*}$ & 15.1 & 26.9 \\
\hline & $2 / 10 / 98$ & 64.5 & 22.0 & 22.7 & $1.8^{*}$ & 14.5 & 26.5 \\
\hline & $5 / 12 / 98$ & 63.6 & 21.5 & 21.3 & $1.8^{*}$ & 15.3 & 26.4 \\
\hline & $8 / 4 / 98$ & 60.1 & 22.0 & 21.7 & $1.68^{*}$ & 14.5 & 26.9 \\
\hline & $11 / 3 / 98$ & 64.8 & 20.6 & 22.6 & $1.7^{*}$ & 14.7 & 25.1 \\
\hline QAS-66B & $11 / 3 / 98$ & ND & ND & ND & ND & ND & ND \\
\hline
\end{tabular}


Table 3. Concentrations of dissolved anions and total cations in water, Naval Reactors Facility and vicinityContinued

\begin{tabular}{clcccccc}
\hline $\begin{array}{c}\text { Sample } \\
\text { identifier }\end{array}$ & $\begin{array}{c}\text { Date sampled } \\
\mathbf{m} / \mathbf{d} / \mathbf{y}\end{array}$ & $\begin{array}{c}\text { Calcium } \\
\text { (total) }\end{array}$ & $\begin{array}{c}\text { Chloride } \\
\text { (dissolved) }\end{array}$ & $\begin{array}{c}\text { Magnesium } \\
\text { (total) }\end{array}$ & $\begin{array}{c}\text { Potassium } \\
\text { (total) }\end{array}$ & $\begin{array}{c}\text { Sodium } \\
\text { (total) }\end{array}$ & $\begin{array}{c}\text { Sulfate } \\
\text { (dissolved) }\end{array}$ \\
\hline USGS 102 & $6 / 9 / 97$ & 74.4 & 38.9 & 23.9 & $2.3^{*}$ & 15.2 & 36.5 \\
& $9 / 3 / 97$ & 76.2 & 36.8 & 23.4 & $2.4^{*}$ & 15.2 & 36.4 \\
& $11 / 17 / 97$ & 73.2 & 35.7 & 23.6 & ND & 15.1 & 36.3 \\
& $2 / 9 / 98$ & 75.7 & 36.1 & 24.0 & $2.6^{*}$ & 15.1 & 35.5 \\
& $5 / 11 / 98$ & 76.0 & 35.7 & 23.2 & $2.2^{*}$ & 15.1 & 35.7 \\
& $\mathbf{8} 3 / 3 / 98$ & 71.9 & 36.6 & 23.5 & $2.34 *$ & 16.0 & 36.1 \\
QAS-65R & $11 / 2 / 98$ & 77.0 & 35.2 & 24.7 & $2.0^{*}$ & 15.1 & 34.1 \\
\hline
\end{tabular}


Table 4. Statistical parameters for dissolved anions and total cations, by well

[See figure 2 for well locations. Units are milligrams per liter. Values are derived from table 3. Quality-assurance replicates are included in the calculation of statistical parameters. Mean and median sample size: includes all samples with concentrations greater than laboratory reporting limit and estimated results. *, results were estimated; ND, not detected]

\begin{tabular}{|c|c|c|c|c|c|c|}
\hline \multirow[b]{2}{*}{ Constituent } & \multicolumn{6}{|c|}{ Statistical parameter } \\
\hline & Minimum & Maximum & Median & Mean & Sample size & $\begin{array}{l}\text { Mean and median } \\
\text { sample size }\end{array}$ \\
\hline \multicolumn{7}{|c|}{ NRF-6 } \\
\hline Calcium & 124 & 141 & 132 & 132 & 8 & 8 \\
\hline Chloride & 209 & 267 & 254 & 249 & 8 & 8 \\
\hline Magnesium & 32.1 & 35.9 & 33.85 & 34 & 8 & 8 \\
\hline Potassium & $4.5^{*}$ & 5.7 & 5.0 & $5.0^{*}$ & 8 & 8 \\
\hline Sodium & 100 & 124 & 118 & 116 & 8 & 8 \\
\hline Sulfate & 145 & 194 & 165.5 & 170 & 8 & 8 \\
\hline \multicolumn{7}{|c|}{ NRF-7 } \\
\hline Calcium & 24.1 & 31.9 & 27.95 & 28.4 & 8 & 8 \\
\hline Chloride & 4.0 & 4.9 & 4.55 & 4.5 & 8 & 8 \\
\hline Magnesium & 8.9 & 10.1 & 9.5 & 9.5 & 8 & 8 \\
\hline Potassium & $2.72^{*}$ & $3.3^{*}$ & $3.0^{*}$ & 3.0 & 8 & 8 \\
\hline Sodium & 8.27 & 9.9 & 9.25 & 9.1 & 8 & 8 \\
\hline Sulfate & 13.1 & 13.9 & 13.55 & 13.6 & 8 & 8 \\
\hline \multicolumn{7}{|c|}{ NRF-8 } \\
\hline Calcium & 70.3 & 76.3 & 75.2 & 74.2 & 7 & 7 \\
\hline Chloride & 35.1 & 39.3 & 36.1 & 36.4 & 7 & 7 \\
\hline Magnesium & 23.3 & 24.6 & 24.1 & 24.0 & 7 & 7 \\
\hline Potassium & $2.2^{*}$ & $2.6^{*}$ & $2.3^{*}$ & $2.4^{*}$ & 7 & 7 \\
\hline Sodium & 14.8 & 16.3 & 15.1 & 15.2 & 7 & 7 \\
\hline Sulfate & 34.8 & 37.5 & 36.2 & 36.2 & 7 & 7 \\
\hline \multicolumn{7}{|c|}{ NRF-9 } \\
\hline Calcium & 72.2 & 80.2 & 78.8 & 77.6 & 8 & 8 \\
\hline Chloride & 44.4 & 51.0 & 47.0 & 47.2 & 8 & 8 \\
\hline Magnesium & 23.3 & 25.2 & 24.55 & 24.5 & 8 & 8 \\
\hline Potassium & $2.2^{*}$ & $2.8^{*}$ & $2.595^{*}$ & $2.6^{*}$ & 8 & 8 \\
\hline Sodium & 15.0 & 19.7 & 18.3 & 18.2 & 8 & 8 \\
\hline Sulfate & 44.1 & 48.5 & 46.8 & 46.9 & 8 & 8 \\
\hline \multicolumn{7}{|c|}{ NRF-10 } \\
\hline Calcium & 69.2 & 77.6 & 75.6 & 74.8 & 7 & 7 \\
\hline Chloride & 42.5 & 47.1 & 44.7 & 44.7 & 7 & 7 \\
\hline Magnesium & 23.1 & 25.1 & 24.2 & 24.1 & 7 & 7 \\
\hline Potassium & $2.2^{*}$ & $3.1^{*}$ & $2.6^{*}$ & $2.6^{*}$ & 7 & 7 \\
\hline Sodium & 15.2 & 18.9 & 15.8 & 16.3 & 7 & 7 \\
\hline Sulfate & 40.7 & 45.8 & 43.7 & 43.8 & 7 & 7 \\
\hline
\end{tabular}


Table 4. Statistical parameters for dissolved anions and total cations, by well-Continued

\begin{tabular}{|c|c|c|c|c|c|c|}
\hline \multirow[b]{2}{*}{ Constituent } & \multicolumn{6}{|c|}{ Statistical parameter } \\
\hline & Minimum & Maximum & Median & Mean & Sample size & $\begin{array}{l}\text { Mean and median } \\
\text { sample size }\end{array}$ \\
\hline \multicolumn{7}{|c|}{ NRF-11 } \\
\hline Calcium & 69.5 & 80.3 & 74.15 & 74.1 & 8 & 8 \\
\hline Chloride & 42.9 & 48.0 & 43.7 & 44.3 & 8 & 8 \\
\hline Magnesium & 22.9 & 24.8 & 23.55 & 23.6 & 8 & 8 \\
\hline Potassium & $2.28^{*}$ & $2.8^{*}$ & $2.65^{*}$ & $2.6^{*}$ & 8 & 8 \\
\hline Sodium & 17.6 & 20.5 & 18.1 & 18.4 & 8 & 8 \\
\hline Sulfate & 41.4 & 49.1 & 44.15 & 44.4 & 8 & 8 \\
\hline \multicolumn{7}{|c|}{ NRF-12 } \\
\hline Calcium & 76.5 & 82.3 & 80.65 & 80.1 & 8 & 8 \\
\hline Chloride & 60.0 & 64.6 & 61.7 & 62.4 & 8 & 8 \\
\hline Magnesium & 24.1 & 26.3 & 24.85 & 25.0 & 8 & 8 \\
\hline Potassium & $2.6^{*}$ & $3.0^{*}$ & $2.7^{*}$ & $2.8^{*}$ & 8 & 8 \\
\hline Sodium & 22.2 & 25.7 & 23.35 & 23.5 & 8 & 8 \\
\hline Sulfate & 52.4 & 60.9 & 60.05 & 58.9 & 8 & 8 \\
\hline \multicolumn{7}{|c|}{ NRF-13 } \\
\hline Calcium & 61.8 & 103 & 73.3 & 75.8 & 7 & 7 \\
\hline Chloride & 63.3 & 69.4 & 66.7 & 66.7 & 7 & 7 \\
\hline Magnesium & 16.9 & 32.6 & 20.7 & 21.9 & 7 & 7 \\
\hline Potassium & $4.0^{*}$ & $4.9^{*}$ & $4.2^{*}$ & $4.4^{*}$ & 7 & 7 \\
\hline Sodium & 10.7 & 14.1 & 11.2 & 11.6 & 7 & 7 \\
\hline Sulfate & 74.8 & 85.8 & 78.8 & 79.9 & 7 & 7 \\
\hline \multicolumn{7}{|c|}{ USGS 12} \\
\hline Calcium & 57.4 & 70.9 & 65.6 & 63.9 & 8 & 8 \\
\hline Chloride & 19.6 & 36.3 & 27.55 & 27.7 & 8 & 8 \\
\hline Magnesium & 18.6 & 22.7 & 20.3 & 20.6 & 8 & 8 \\
\hline Potassium & $1.8^{*}$ & $2.3^{*}$ & $2.05^{*}$ & $2.0^{*}$ & 8 & 8 \\
\hline Sodium & 14.5 & 17.7 & 16.25 & 16.0 & 8 & 8 \\
\hline Sulfate & 25.0 & 35.4 & 29.4 & 29.9 & 8 & 8 \\
\hline \multicolumn{7}{|c|}{ USGS 97} \\
\hline Calcium & 70.3 & 77.1 & 74.6 & 74.3 & 7 & 7 \\
\hline Chloride & 35.5 & 39.4 & 36.2 & 36.8 & 7 & 7 \\
\hline Magnesium & 23.5 & 25.2 & 24.1 & 24.2 & 7 & 7 \\
\hline Potassium & $2.0^{*}$ & $2.4^{*}$ & $2.2^{*}$ & $2.2^{*}$ & 7 & 7 \\
\hline Sodium & 15.6 & 16.4 & 15.9 & 15.9 & 7 & 7 \\
\hline Sulfate & 34.8 & 36.7 & 36.2 & 36.0 & 7 & 7 \\
\hline
\end{tabular}


Table 4. Statistical parameters for dissolved anions and total cations, by well-Continued

\begin{tabular}{|c|c|c|c|c|c|c|}
\hline \multirow[b]{2}{*}{ Constituent } & \multicolumn{6}{|c|}{ Statistical parameter } \\
\hline & Minimum & Maximum & Median & Mean & Sample size & $\begin{array}{l}\text { Mean and median } \\
\text { sample size }\end{array}$ \\
\hline \multicolumn{7}{|c|}{ USGS 98} \\
\hline Calcium & 48.0 & 53.0 & 51.3 & 51.0 & 7 & 7 \\
\hline Chloride & 13.9 & 15.1 & 14.6 & 14.4 & 7 & 7 \\
\hline Magnesium & 18.3 & 20.1 & 19.7 & 19.5 & 7 & 7 \\
\hline Potassium & $1.8^{*}$ & $2.3^{*}$ & $2.03^{*}$ & $2.1^{*}$ & 7 & 7 \\
\hline Sodium & 9.3 & 10.4 & 9.68 & 9.7 & 7 & 7 \\
\hline Sulfate & 21.0 & 22.2 & 21.8 & 21.7 & 7 & 7 \\
\hline \multicolumn{7}{|c|}{ USGS 99} \\
\hline Calcium & 60.1 & 65.6 & 63.7 & 63.7 & 7 & 7 \\
\hline Chloride & 20.6 & 23.0 & 21.5 & 21.7 & 7 & 7 \\
\hline Magnesium & 21.3 & 23.2 & 22.6 & 22.3 & 7 & 7 \\
\hline Potassium & $1.68^{*}$ & $2.0 *$ & $1.8^{*}$ & $1.8^{*}$ & 7 & 7 \\
\hline Sodium & 14.5 & 15.8 & 15.1 & 15.0 & 7 & 7 \\
\hline Sulfate & 25.1 & 26.9 & 26.4 & 26.2 & 7 & 7 \\
\hline \multicolumn{7}{|c|}{ USGS 102} \\
\hline Calcium & 71.9 & 77.0 & 75.85 & 75.1 & 8 & 8 \\
\hline Chloride & 35.2 & 38.9 & 35.9 & 36.3 & 8 & 8 \\
\hline Magnesium & 23.2 & 24.7 & 23.75 & 23.9 & 8 & 8 \\
\hline Potassium & ND & $2.6^{*}$ & $2.3^{*}$ & $2.3^{*}$ & 8 & 7 \\
\hline Sodium & 15.1 & 16.0 & 15.15 & 15.3 & 8 & 8 \\
\hline Sulfate & 34.1 & 36.5 & 35.9 & 35.6 & 8 & 8 \\
\hline
\end{tabular}




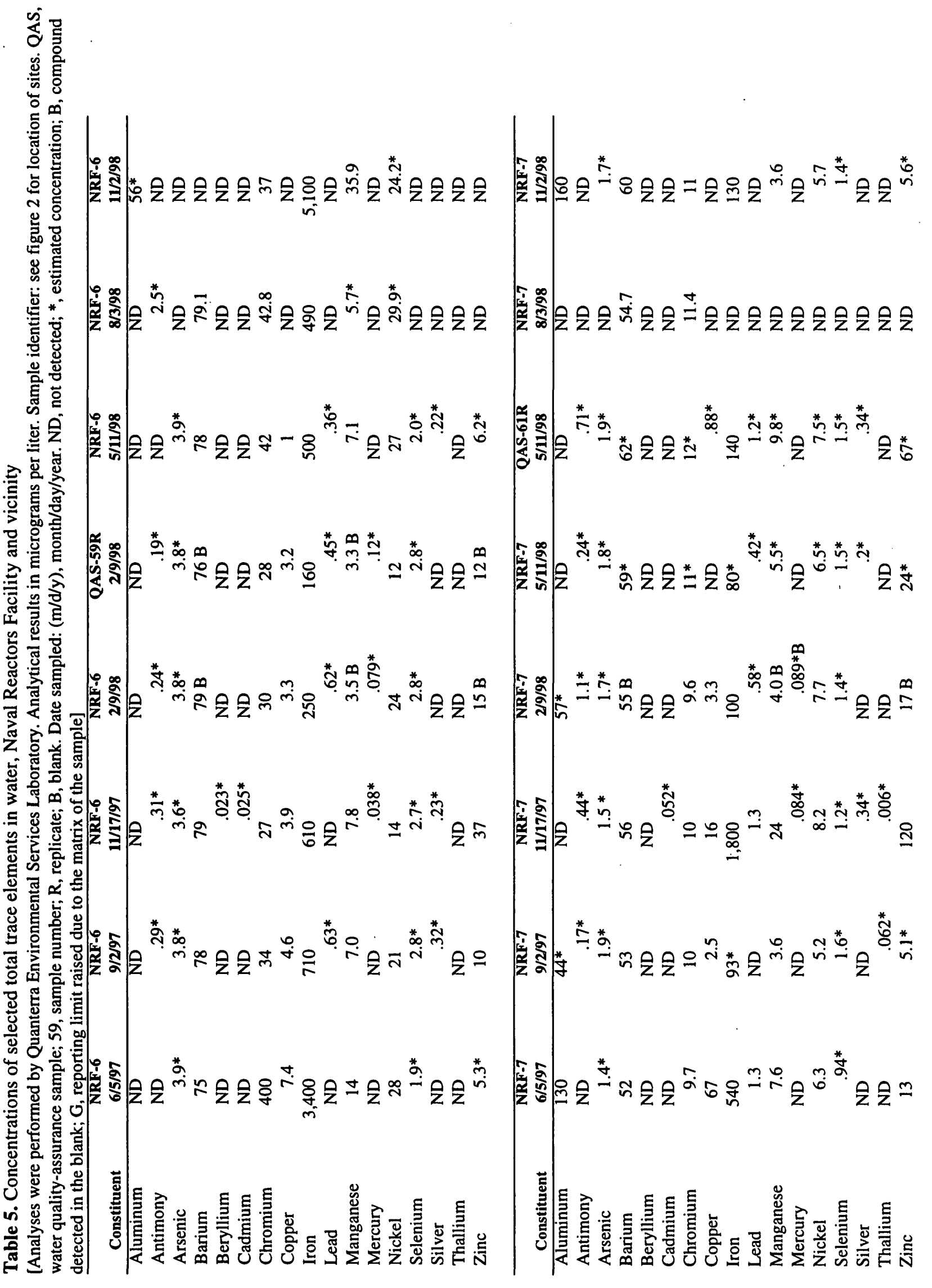




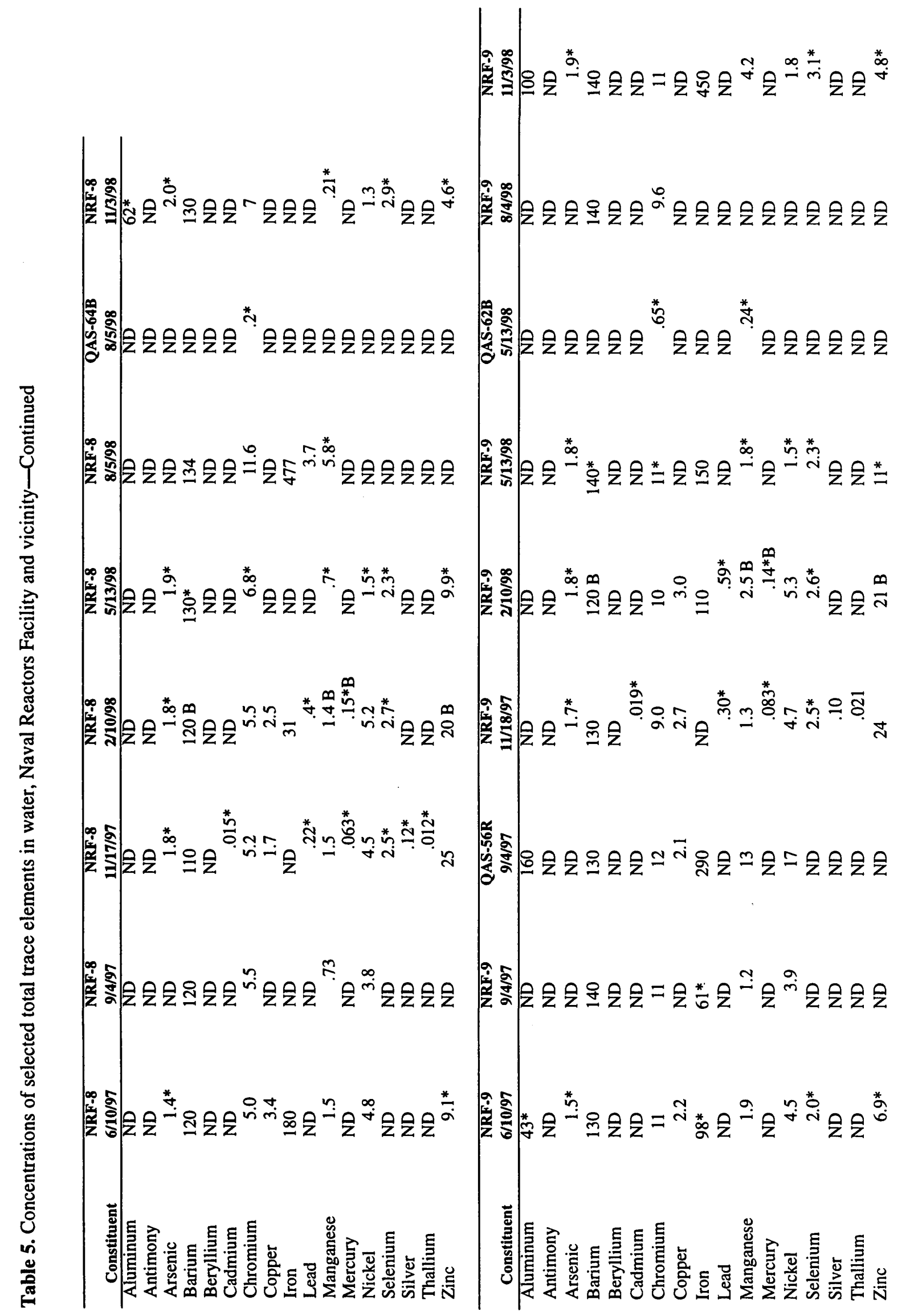




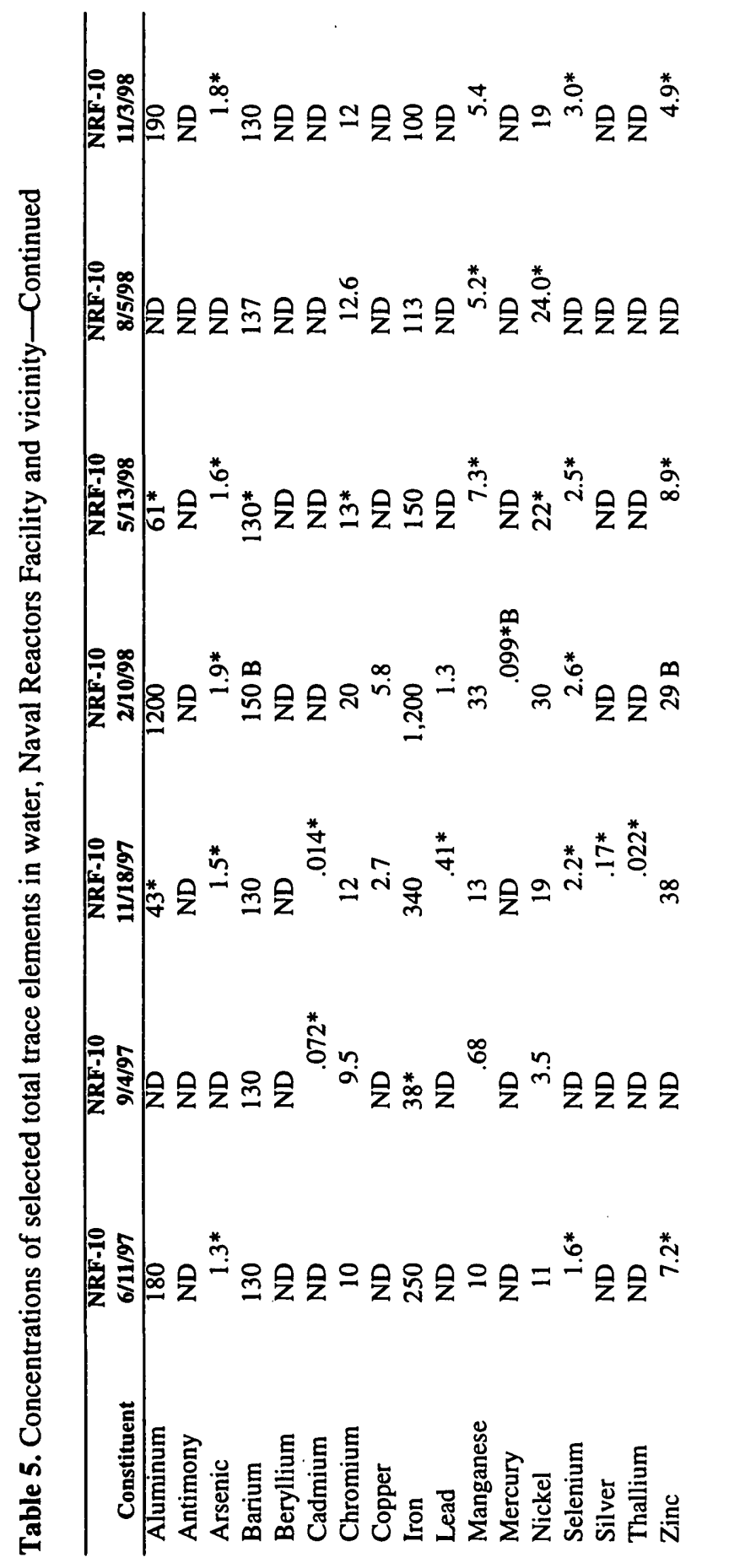

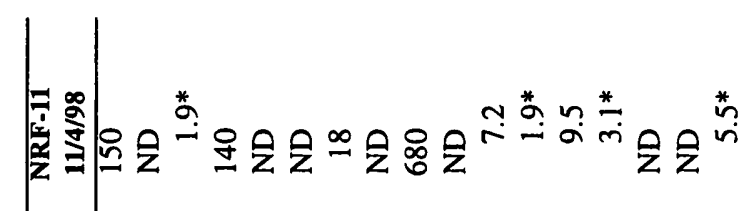

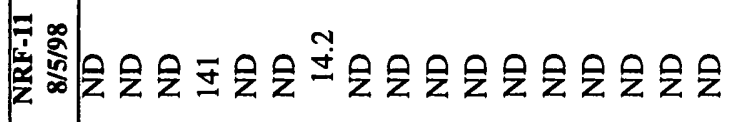

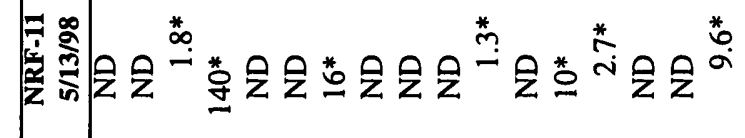

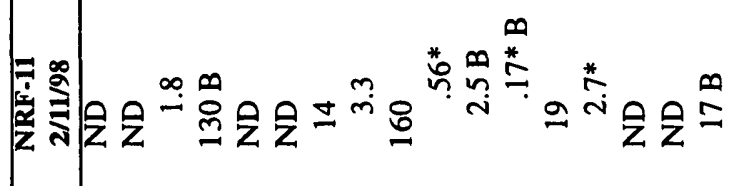

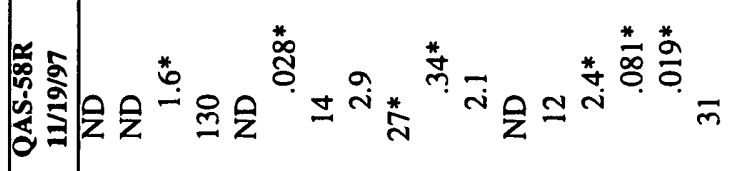

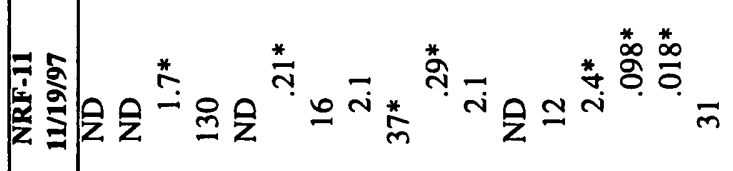

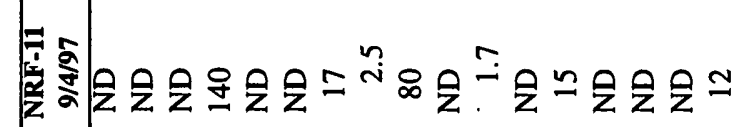

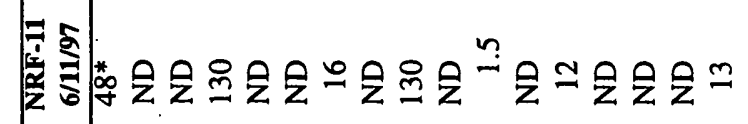

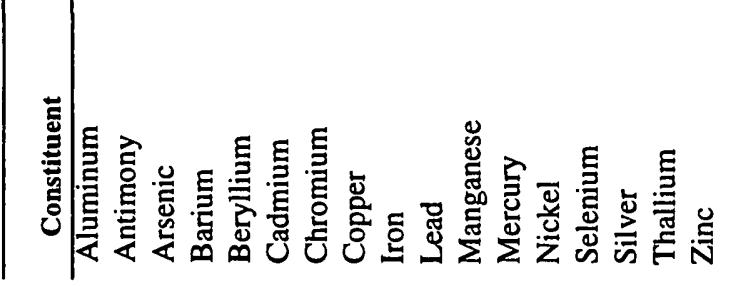



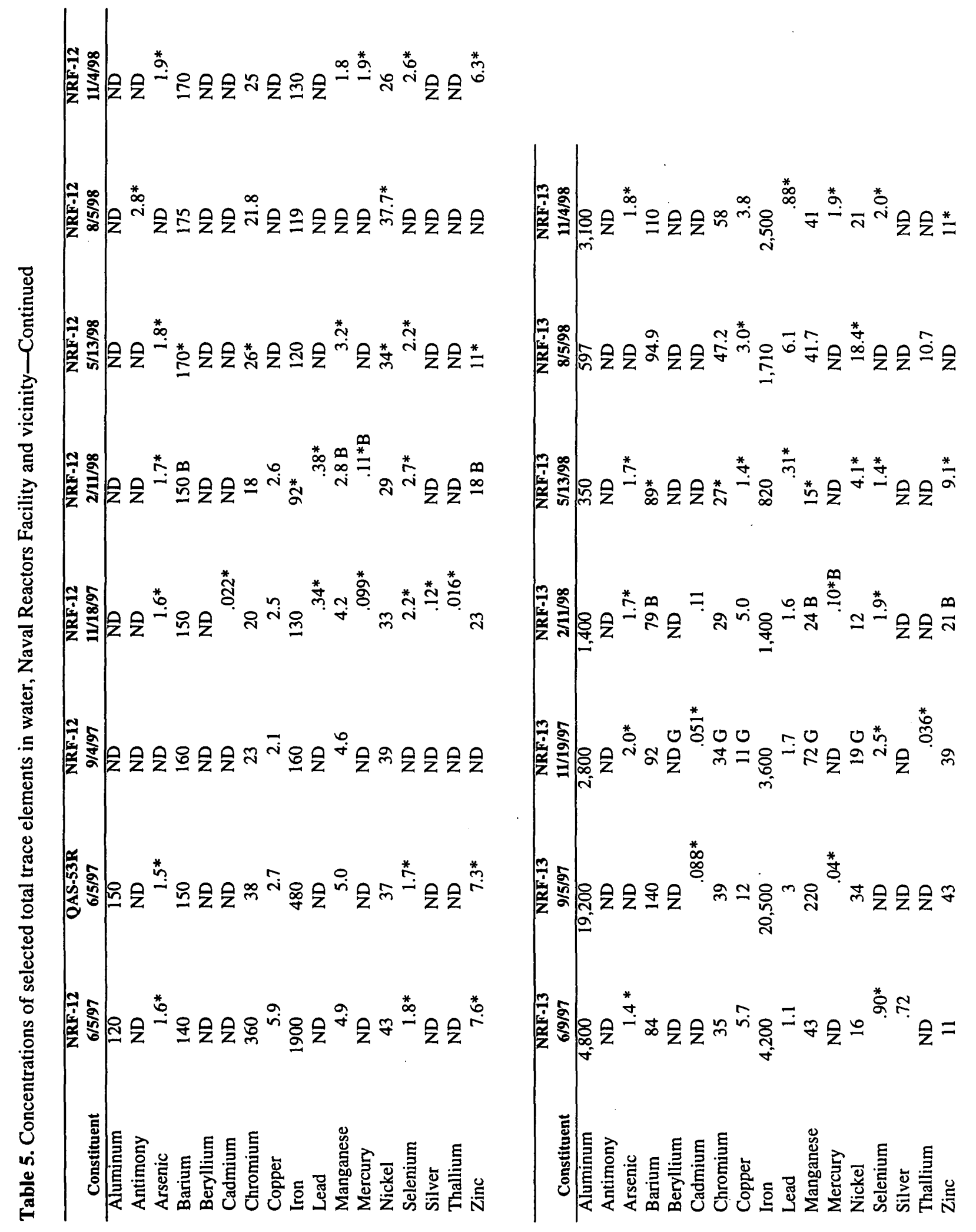


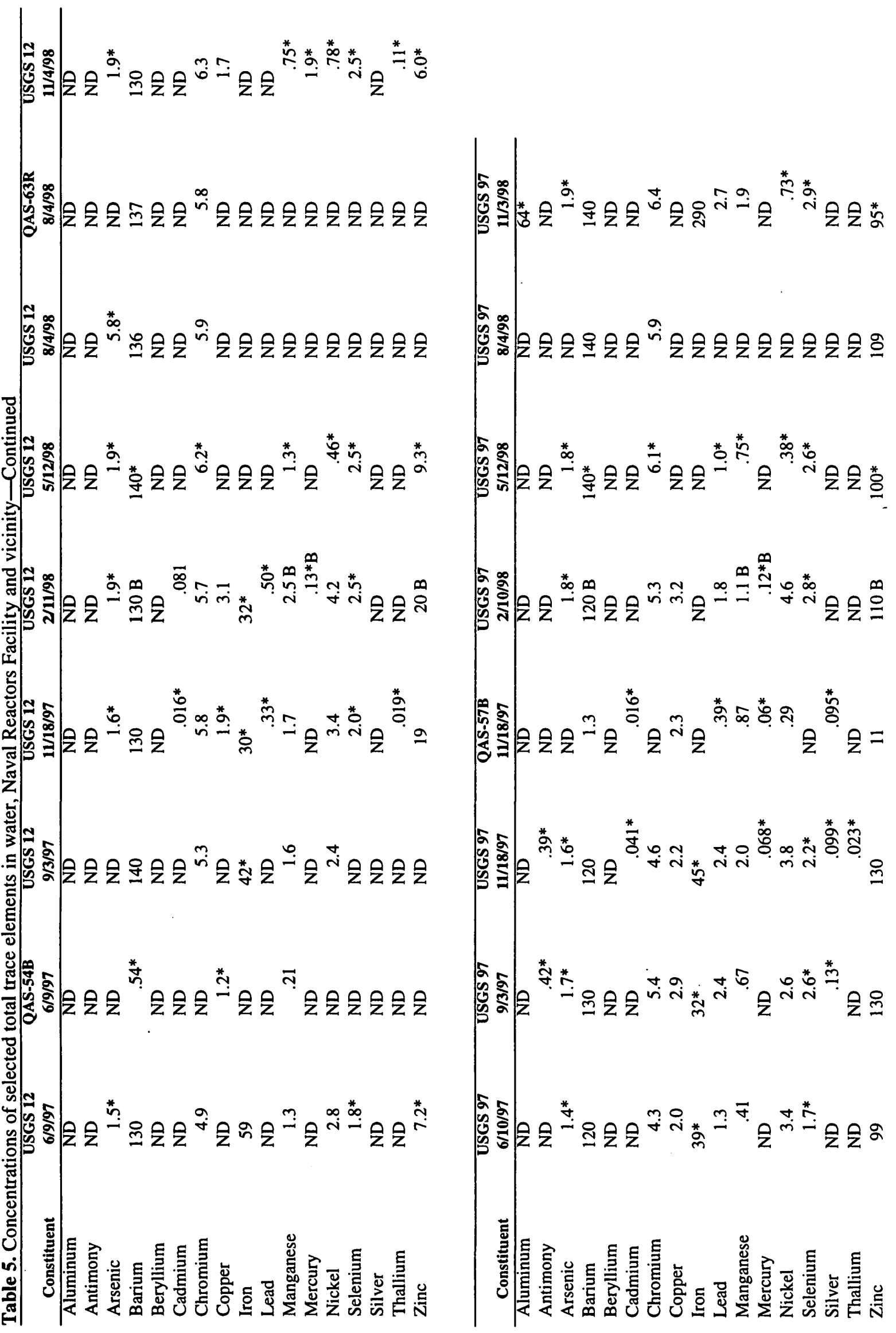




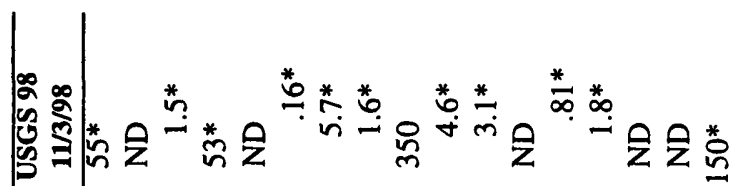

兑

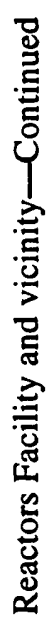

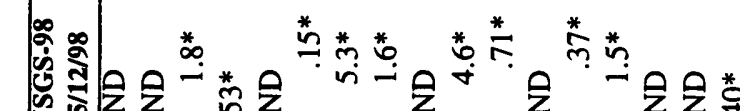

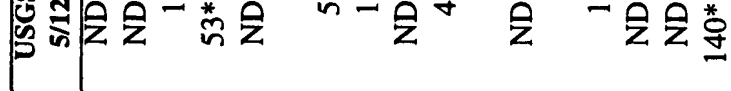

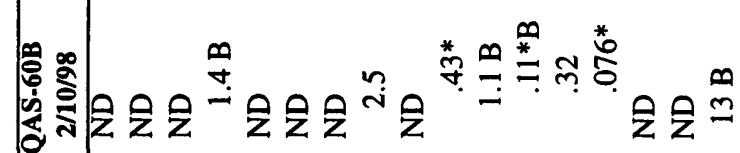

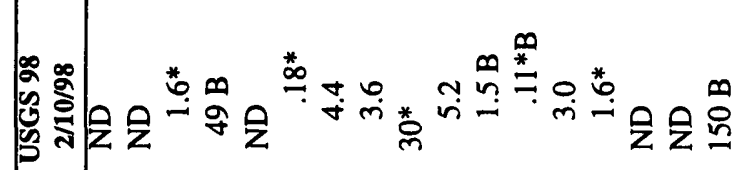

ב

密

3

플

跤

\&

蹗

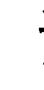

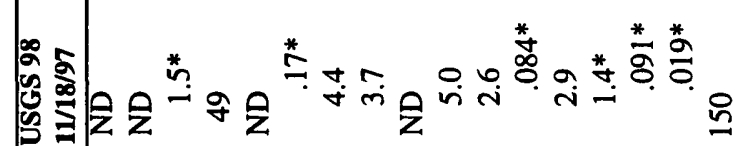

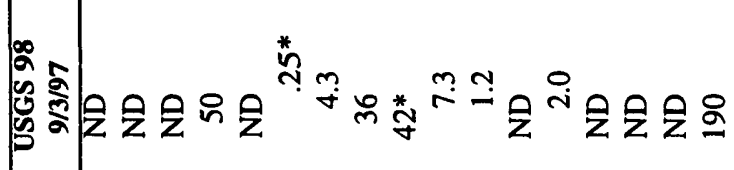

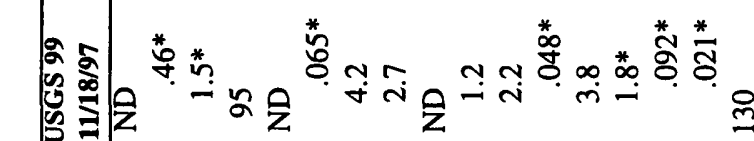

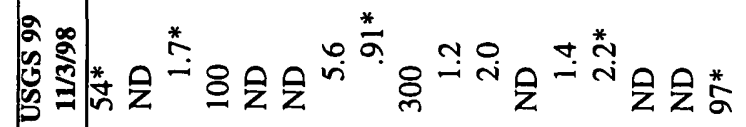

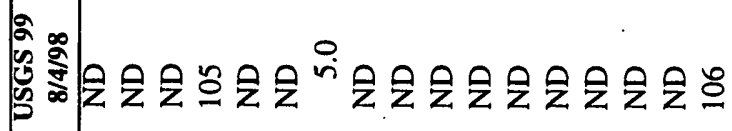

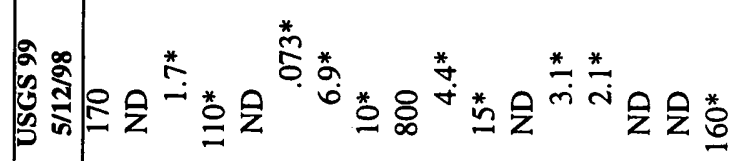

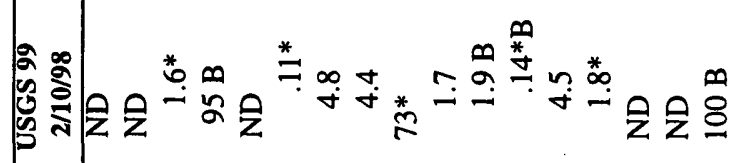

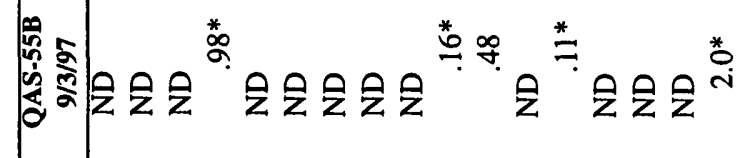

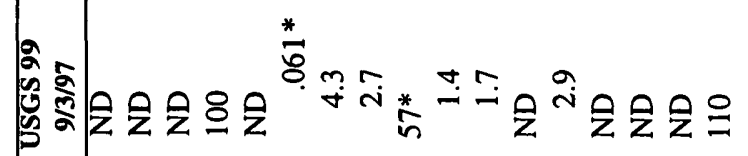

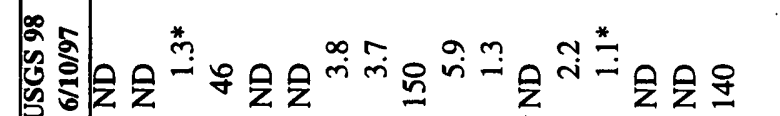

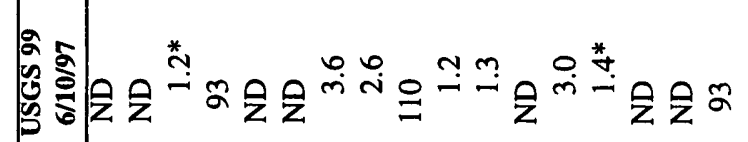

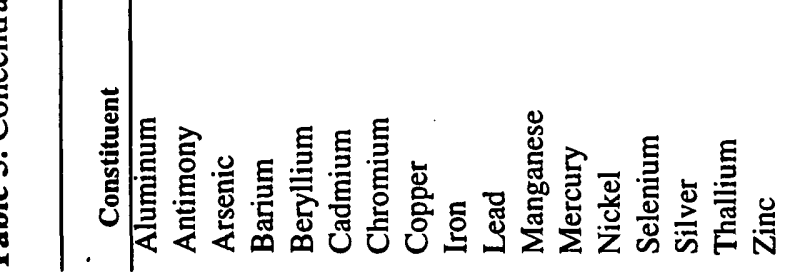




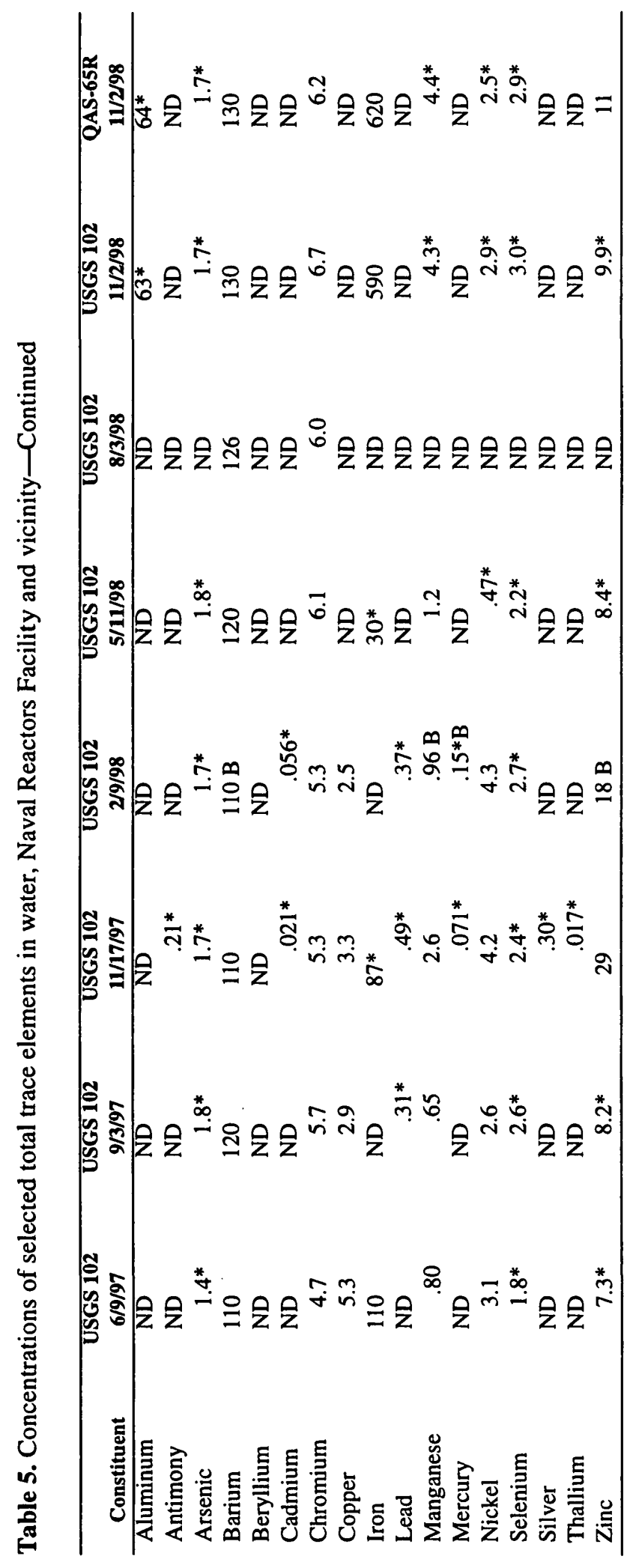


Table 6. Statistical parameters for selected total trace elements, by well

[See figure 2 for well locations. Units are milligrams per liter. Values are derived from table 5. Quality-assurance replicates are included in the calculation of statistical parameters. Mean and median sample size: includes all samples with concentrations greater than laboratory reporting limit and estimated results. *, results were estimated; ND, not detected]

\begin{tabular}{|c|c|c|c|c|c|c|}
\hline \multirow[b]{2}{*}{ Constituent } & \multicolumn{6}{|c|}{ Statistical parameter } \\
\hline & Minimum & Maximum & Median & Mean & Sample size & $\begin{array}{c}\text { Mean and } \\
\text { median sample } \\
\text { size }\end{array}$ \\
\hline \multicolumn{7}{|c|}{ NRF-6 } \\
\hline Antimony & ND & $2.5^{*}$ & $.29 *$ & $.71^{*}$ & 8 & 5 \\
\hline Arsenic & ND & $3.9^{*}$ & $3.8^{*}$ & $3.8^{*}$ & 8 & 6 \\
\hline Barium & ND & 79.1 & 78 & 77.7 & 8 & 7 \\
\hline Chromium & ND & 42.8 & 34 & 34.4 & 8 & 7 \\
\hline Copper & ND & 7.4 & 3.6 & 3.9 & 8 & 6 \\
\hline Iron & 160 & 5,100 & 555 & 1,400 & 8 & 8 \\
\hline Lead & ND & $.63^{*}$ & $.535 *$ & $.52^{*}$ & 8 & 4 \\
\hline Manganese & 3.3 & 35.9 & 7.05 & $10.5^{*}$ & 8 & 8 \\
\hline Mercury & ND & $.12^{*}$ & $.079 *$ & $.079 *$ & 8 & 3 \\
\hline Nickel & 12 & $29.9^{*}$ & $24.1^{*}$ & $22.5^{*}$ & 8 & 8 \\
\hline Selenium & ND & $2.8^{*}$ & $2.75^{*}$ & $2.5^{*}$ & 8 & 6 \\
\hline Silver & ND & $.32^{*}$ & $.23^{*}$ & $.26^{*}$ & 8 & 3 \\
\hline Zinc & ND & 37 & 11 & $14.2^{*}$ & 8 & 6 \\
\hline \multicolumn{7}{|c|}{ NRF-7 } \\
\hline Aluminum & ND & 160 & $93.5^{*}$ & $98 *$ & 8 & 4 \\
\hline Antimony & ND & $1.1^{*}$ & $.44^{*}$ & $.53^{*}$ & 8 & 5 \\
\hline Arsenic & ND & $1.9^{*}$ & $1.7^{*}$ & $1.7^{*}$ & 8 & 7 \\
\hline Barium & 52 & $62^{*}$ & 55.5 & $56.5^{*}$ & 8 & 8 \\
\hline Chromium & 9.6 & $12^{*}$ & $10.5^{*}$ & $10.6^{*}$ & 8 & 8 \\
\hline Copper & ND & 67 & 3.3 & $18^{*}$ & 8 & 5 \\
\hline Iron & ND & 1,800 & 130 & $410^{*}$ & 8 & 7 \\
\hline Lead & ND & 1.3 & $1.2^{*}$ & $.96 *$ & 8 & 5 \\
\hline Manganese & ND & 24 & $5.5^{*}$ & $8.3^{*}$ & 8 & 7 \\
\hline Nickel & ND & 8.2 & $6.5^{*}$ & $6.7^{*}$ & 8 & 7 \\
\hline Selenium & ND & $1.6^{*}$ & $1.4^{*}$ & $1.4^{*}$ & 8 & 7 \\
\hline Silver & ND & $.34^{*}$ & $.34^{*}$ & $.29 *$ & 8 & 3 \\
\hline Zinc & ND & 120 & 17 & $36^{*}$ & 8 & 7 \\
\hline \multicolumn{7}{|c|}{ NRF.8 } \\
\hline Arsenic & ND & $2.0^{*}$ & $1.8^{*}$ & $1.8^{*}$ & 7 & 5 \\
\hline Barium & 110 & 134 & 120 & $123 *$ & 7 & 7 \\
\hline Chromium & 5.0 & 11.6 & 5.5 & $6.7 *$ & 7 & 7 \\
\hline Copper & ND & 3.4 & 2.5 & 2.5 & 7 & 3 \\
\hline Iron & ND & 477 & 180 & 229 & 7 & 3 \\
\hline Lead & ND & 3.7 & $.4^{*}$ & $1.44^{*}$ & 7 & 3 \\
\hline Manganese & $.21^{*}$ & $5.8^{*}$ & 1.4 & $1.7^{*}$ & 7 & 7 \\
\hline
\end{tabular}


Table 6. Statistical parameters for selected total trace elements, by well-Continued

\begin{tabular}{|c|c|c|c|c|c|c|}
\hline \multirow[b]{2}{*}{ Constituent } & \multicolumn{6}{|c|}{ Statistical parameter } \\
\hline & Minimum & Maximum & Median & Mean & Sample size & $\begin{array}{c}\text { Mean and } \\
\text { median sample } \\
\text { size }\end{array}$ \\
\hline \multicolumn{7}{|c|}{ NRF-8-cont. } \\
\hline Nickel & ND & 5.2 & 4.15 & $3.5^{*}$ & 7 & 6 \\
\hline Selenium & ND & $2.9^{*}$ & $2.6^{*}$ & $2.6^{*}$ & 7 & 4 \\
\hline Zinc & ND & 25 & $9.9 *$ & $13.7^{*}$ & 7 & 5 \\
\hline \multicolumn{7}{|c|}{ NRF-9 } \\
\hline Arsenic & ND & $1.9^{*}$ & $1.8^{*}$ & $1.7^{*}$ & 7 & 5 \\
\hline Barium & 120 & $140^{*}$ & $140^{*}$ & $130^{*}$ & 7 & 7 \\
\hline Chromium & 9.0 & 11 & $11^{*}$ & $10.4^{*}$ & 7 & 7 \\
\hline Copper & ND & 3.0 & 2.7 & 2.6 & 7 & 3 \\
\hline Iron & ND & 450 & 110 & 174 & 7 & 5 \\
\hline Manganese & ND & 4.2 & $1.85^{*}$ & $2.2^{*}$ & 7 & 6 \\
\hline Nickel & ND & 5.3 & 4.2 & $3.6^{*}$ & 7 & 6 \\
\hline Selenium & ND & $3.1^{*}$ & $2.5^{*}$ & $2.5^{*}$ & 7 & 5 \\
\hline Zinc & ND & 24 & $11^{*}$ & $13.5^{*}$ & 7 & 5 \\
\hline \multicolumn{7}{|c|}{ NRF-10 } \\
\hline Aluminum & ND & 1,200 & 180 & $335^{*}$ & 7 & 5 \\
\hline Arsenic & ND & $1.9^{*}$ & $1.6^{*}$ & $1.6^{*}$ & 7 & 5 \\
\hline Barium & $130^{*}$ & 150 & $130^{*}$ & $134^{*}$ & 7 & 7 \\
\hline Chromium & 9.5 & 20 & 12 & $12.7^{*}$ & 7 & 7 \\
\hline Iron & $38^{*}$ & 1,200 & 150 & 313 & 7 & 7 \\
\hline Manganese & .68 & 33 & 7.3* & $10.7^{*}$ & 7 & 7 \\
\hline Nickel & 3.5 & 30 & 19 & $18.4^{*}$ & 7 & 7 \\
\hline Selenium & ND & $3.0^{*}$ & $2.5^{*}$ & $2.4^{*}$ & 7 & 5 \\
\hline Zinc & ND & 38 & $8.9^{*}$ & $17.6^{*}$ & 7 & 5 \\
\hline \multicolumn{7}{|c|}{ NRF-11 } \\
\hline Arsenic & ND & $3.8^{*}$ & $1.8^{*}$ & $2.2^{*}$ & 8 & 5 \\
\hline Barium & 76 & 141 & $135^{*}$ & $128^{*}$ & 8 & 8 \\
\hline Chromium & 14 & 28 & 16 & $17.4^{*}$ & 8 & 8 \\
\hline Copper & ND & 3.2 & 2.7 & 2.7 & 8 & 4 \\
\hline Iron & ND & 680 & 105 & $186^{*}$ & 8 & 6 \\
\hline Lead & ND & $.45^{*}$ & $.34 *$ & $.36^{*}$ & 8 & 3 \\
\hline Manganese & ND & 7.2 & 2.1 & $2.7^{*}$ & 8 & 7 \\
\hline Nickel & ND & 15 & 12 & $11.8^{*}$ & 8 & 7 \\
\hline Selenium & ND & $3.1^{*}$ & $2.7^{*}$ & $2.7^{*}$ & 8 & 5 \\
\hline Zinc & ND & 31 & 12 & $16.3^{*}$ & 8 & 7 \\
\hline \multicolumn{7}{|c|}{ NRF-12 } \\
\hline Arsenic & ND & $1.9^{*}$ & $1.65^{*}$ & $1.7^{*}$ & 8 & 6 \\
\hline Barium & 140 & 175 & 155 & $158^{*}$ & 8 & 8 \\
\hline Chromium & 18 & 360 & 24 & $66.5^{*}$ & 8 & 8 \\
\hline
\end{tabular}


Table 6. Statistical parameters for selected total trace elements, by well-Continued

\begin{tabular}{|c|c|c|c|c|c|c|}
\hline \multirow[b]{2}{*}{ Constituent } & \multicolumn{6}{|c|}{ Statistical parameter } \\
\hline & Minimum & Maximum & Median & Mean & Sample size & $\begin{array}{c}\text { Mean and } \\
\text { median sample } \\
\text { size }\end{array}$ \\
\hline \multicolumn{7}{|c|}{ NRF-12-cont } \\
\hline Copper & ND & 5.9 & 2.6 & 3.2 & 8 & 5 \\
\hline Iron & $92^{*}$ & 1900 & 130 & 391 & 8 & 8 \\
\hline Manganese & ND & 5.0 & 4.2 & $3.8^{*}$ & 8 & 7 \\
\hline Mercury & ND & $1.9 *$ & $.11^{*}$ & $.70^{*}$ & 8 & 3 \\
\hline Nickel & 26 & 43 & 35.5 & $35^{*}$ & 8 & 8 \\
\hline Selenium & ND & $2.7^{*}$ & $2.2^{*}$ & $2.2^{*}$ & 8 & 6 \\
\hline Zinc & ND & 23 & $9.3^{*}$ & $12.2^{*}$ & 8 & 6 \\
\hline \multicolumn{7}{|c|}{ NRF-13 } \\
\hline Aluminum & 350 & 19,200 & 2,800 & 4,600 & 7 & 7 \\
\hline Arsenic & ND & $2.0^{*}$ & $1.75^{*}$ & $1.7^{*}$ & 7 & 6 \\
\hline Barium & 79 & 120 & 92 & $95.6^{*}$ & 7 & 7 \\
\hline Chromium & 5.7 & 58 & 34 & $33.7 *$ & 7 & 7 \\
\hline Copper & $1.4^{*}$ & 11 & 3.8 & $4.7^{*}$ & 7 & 7 \\
\hline Iron & 820 & 20,500 & 2,500 & 4,960 & 7 & 7 \\
\hline Lead & $.31^{*}$ & 6.1 & 1.1 & $1.7^{*}$ & 7 & 7 \\
\hline Manganese & .65 & 72 & 41 & $33.9^{*}$ & 7 & 7 \\
\hline Mercury & ND & $1.9 *$ & $.10^{*}$ & $.68^{*}$ & 7 & 3 \\
\hline Nickel & 2.6 & 21 & 16 & $13.3^{*}$ & 7 & 7 \\
\hline Selenium & ND & $2.6^{*}$ & $1.95^{*}$ & $1.9^{*}$ & 7 & 6 \\
\hline Zinc & ND & 39 & $11^{*}$ & 16.6 & 7 & 6 \\
\hline \multicolumn{7}{|c|}{ USGS 12} \\
\hline Arsenic & ND & $5.8^{*}$ & $1.9^{*}$ & $2.4^{*}$ & 8 & 6 \\
\hline Barium & 130 & $140^{*}$ & 133 & $134^{*}$ & 8 & 8 \\
\hline Chromium & 4.9 & 6.3 & 5.8 & $5.7^{*}$ & 8 & 8 \\
\hline Copper & ND & 3.1 & $1.9^{*}$ & $2.2^{*}$ & 8 & 3 \\
\hline Iron & ND & 59 & $37 *$ & $41^{*}$ & 8 & 4 \\
\hline Manganese & ND & 2.5 & $1.45^{*}$ & $1.5^{*}$ & 8 & 6 \\
\hline Nickel & ND & 4.2 & 2.6 & $2.3^{*}$ & 8 & 6 \\
\hline Selenium & ND & $2.5^{*}$ & $2.5^{*}$ & $2.3^{*}$ & 8 & 5 \\
\hline Zinc & ND & 20 & $9.3^{*}$ & $12.3^{*}$ & 8 & 5 \\
\hline \multicolumn{7}{|c|}{ USGS 97} \\
\hline Arsenic & ND & $1.9^{*}$ & $1.75^{*}$ & $1.7^{*}$ & 7. & 6 \\
\hline Barium & 120 & $140^{*}$ & 130 & $130^{*}$ & 7 & 7 \\
\hline Chromium & 4.3 & 6.4 & 5.4 & 5.4 & 7 & 7 \\
\hline Copper & ND & 3.2 & 2.55 & 2.6 & 7 & 4 \\
\hline Iron & ND & 290 & $42 *$ & $102^{*}$ & 7 & 4 \\
\hline Lead & ND & 2.7 & 2.1 & $1.9^{*}$ & 7 & 6 \\
\hline Manganese & ND & 2.0 & $.925 *$ & $1.1^{*}$ & 7 & 6 \\
\hline
\end{tabular}


Table 6. Statistical parameters for selected total trace elements, by well-Continued

\begin{tabular}{|c|c|c|c|c|c|c|}
\hline \multirow[b]{2}{*}{ Constituent } & \multicolumn{6}{|c|}{ Statistical parameter } \\
\hline & Minimum & Maximum & Median & Mean & Sample size & $\begin{array}{c}\text { Mean and } \\
\text { median sample } \\
\text { size }\end{array}$ \\
\hline \multicolumn{7}{|c|}{ USGS 97 -cont. } \\
\hline Nickel & ND & 4.6 & 3.0 & $2.6^{*}$ & 7 & 6 \\
\hline Selenium & ND & $2.9^{*}$ & $2.6^{*}$ & $2.5^{*}$ & 7 & 6 \\
\hline Zinc & $95 *$ & 130 & 109 & $110^{*}$ & 7 & 7 \\
\hline \multicolumn{7}{|c|}{ USGS 98} \\
\hline Arsenic & ND & $1.8^{*}$ & $1.5 *$ & $1.5^{*}$ & 7 & 5 \\
\hline Barium & 46 & $53^{*}$ & 50 & $50^{*}$ & 7 & 7 \\
\hline Cadmium & ND & $.25^{*}$ & $.17^{*}$ & $.18^{*}$ & 7 & 5 \\
\hline Chromium & 3.8 & $5.7^{*}$ & 4.4 & $4.7^{*}$ & 7 & 7 \\
\hline Copper & ND & 36 & 3.65 & $8.4^{*}$ & 7 & 6 \\
\hline Iron & ND & 350 & $96^{*}$ & $143^{*}$ & 7 & 4 \\
\hline Lead & $4.6^{*}$ & 7.3 & 5.2 & $5.5^{*}$ & 7 & 7 \\
\hline Manganese & ND & $3.1^{*}$ & 1.4 & $1.7^{*}$ & 7 & 6 \\
\hline Nickel & ND & 3.0 & 2.1 & $1.9^{*}$ & 7 & 6 \\
\hline Selenium & ND & $1.8^{*}$ & $1.5 *$ & $1.5^{*}$ & 7 & 5 \\
\hline Zinc & 140 & 190 & 150 & $154^{*}$ & 7 & 7 \\
\hline \multicolumn{7}{|c|}{ USGS 99} \\
\hline Arsenic & ND & $1.7^{*}$ & $1.6^{*}$ & $1.5^{*}$ & 7 & 5 \\
\hline Barium & 93 & $110^{*}$ & 100 & 100 & 7 & 7 \\
\hline Cadmium & ND & $.11^{*}$ & $.069 *$ & $.077^{*}$ & 7 & 4 \\
\hline Chromium & 3.6 & $6.9 *$ & 4.8 & $4.9^{*}$ & 7 & 7 \\
\hline Copper & ND & $10^{*}$ & 2.7 & $3.9 *$ & 7 & 6 \\
\hline Iron & ND & 800 & 110 & $268^{*}$ & 7 & 5 \\
\hline Lead & ND & $4.4^{*}$ & 1.3 & $1.8^{*}$ & 7 & 6 \\
\hline Manganese & ND & $15^{*}$ & 1.95 & $4.0^{*}$ & 7 & 6 \\
\hline Nickel & ND & 4.5 & 3.05 & $3.1^{*}$ & 7 & 6 \\
\hline Selenium & ND & $2.2^{*}$ & $1.8^{*}$ & $1.9 *$ & 7 & 5 \\
\hline Zinc & 93 & $160^{*}$ & 106 & $114^{*}$ & 7 & 7 \\
\hline \multicolumn{7}{|c|}{ USGS 102} \\
\hline Arsenic & ND & $1.8^{*}$ & $1.7^{*}$ & $1.7^{*}$ & 8 & 7 \\
\hline Barium & 110 & 130 & 120 & 120 & 8 & 8 \\
\hline Chromium & 4.7 & 6.7 & 5.85 & 5.8 & 8 & 8 \\
\hline Copper & ND & 5.3 & 3.1 & 3.5 & 8 & 4 \\
\hline Iron & ND & 620 & 110 & 287 & 8 & 5 \\
\hline Lead & ND & .49 & $.37 *$ & $.39 *$ & 8 & 3 \\
\hline Manganese & ND & $4.4^{*}$ & 1.2 & $2.1^{*}$ & 8 & 7 \\
\hline Nickel & ND & 4.3 & $2.9^{*}$ & $2.9^{*}$ & 8 & 7 \\
\hline Selenium & ND & $3.0^{*}$ & $2.6^{*}$ & $2.5^{*}$ & 8 & 7 \\
\hline Zinc & ND & 29 & 9.9* & $13^{*}$ & 8 & 7 \\
\hline
\end{tabular}


Table 7. Concentrations of dissolved and total nutrients, total organic carbon, and total organic halogens in water, Naval Reactors Facility and vicinity

[Analyses were performed by Quanterra Environmental Services Laboratory. Analytical results in milligrams per liter. Sample identifier: see figure 2 for location of sites. QAS, water quality-assurance sample; 59 , sample number; R, replicate; B, field blank. Date sampled: (m/d/y), month/day/year. ND, analysis not detected; *, estimated result; B, compound is also detected in blank; $Q$, reporting limit elevated due to high analyte level; S, sample diluted due to the concentration of target compounds]

\begin{tabular}{|c|c|c|c|c|c|c|c|}
\hline $\begin{array}{c}\text { Sample } \\
\text { identifier }\end{array}$ & $\begin{array}{c}\text { Date } \\
\text { sampled } \\
\text { m/d/y }\end{array}$ & $\begin{array}{c}\text { Kjeldahl } \\
\text { nitrogen } \\
\text { (total) }\end{array}$ & $\begin{array}{c}\text { Nitrite } \\
\text { (dissolved) }\end{array}$ & $\begin{array}{c}\text { Nitrite plus } \\
\text { nitrate (total) }\end{array}$ & $\begin{array}{c}\text { Phosphorus } \\
\text { (total) }\end{array}$ & $\begin{array}{c}\text { Total } \\
\text { organic } \\
\text { carbon }\end{array}$ & $\begin{array}{c}\text { Total } \\
\text { organic } \\
\text { halogens }\end{array}$ \\
\hline \multirow[t]{4}{*}{ NRF-6 } & $6 / 5 / 97$ & ND & ND & 2.0 & .20 & $.67^{*}$ & $.020^{*}$ \\
\hline & $9 / 2 / 97$ & ND & ND & 1.9 & .099 & $.26^{*}$ & $.024^{*}$ \\
\hline & $11 / 17 / 97$ & ND & ND & 1.8 & .12 & $.85^{*}$ & $.019 *$ \\
\hline & $2 / 9 / 98$ & $.32 *$ & $.003^{*}$ & 2.0 & .10 & $.27 *$ & $.014 * \mathrm{~B}$ \\
\hline QAS-59R & $2 / 9 / 98$ & ND & $.004^{*}$ & 2.0 & .13 & $.44 *$ & $.021 * \mathrm{~B}$ \\
\hline \multirow[t]{3}{*}{ NRF-6 } & $5 / 11 / 98$ & $.37^{*}$ & $.002^{*}$ & 1.7 & .11 & $.76^{*}$ & $.013^{*}$ \\
\hline & $8 / 3 / 98$ & ND & ND & 1.6 & .081 & ND & .059 \\
\hline & $11 / 2 / 98$ & $.15^{*}$ & ND & 1.6 & .12 & $.35 *$ & ND \\
\hline \multirow[t]{5}{*}{ NRF-7 } & $6 / 5 / 97$ & ND & ND & .72 & .17 & ND & $.008^{*}$ \\
\hline & $9 / 2 / 97$ & ND & ND & .68 & $.024^{*}$ & ND & ND \\
\hline & $11 / 17 / 97$ & ND & ND & .44 & $.039 *$ & $.31 *$ & ND \\
\hline & $2 / 9 / 98$ & $.094^{*}$ & $.003 *$ & .59 & $.034^{*}$ & ND & $\mathrm{NDB}$ \\
\hline & $5 / 11 / 98$ & $.18^{*}$ & $.002^{*}$ & .47 & $.022^{*}$ & ND & ND \\
\hline QAS-61R & $5 / 11 / 98$ & $.12^{*}$ & $.001^{*}$ & .47 & $.022^{*}$ & $.24 *$ & ND \\
\hline \multirow[t]{2}{*}{ NRF-7 } & $8 / 3 / 98$ & ND & ND & .47 & $.022^{*}$ & ND & ND \\
\hline & $11 / 2 / 98$ & ND & ND & .46 & $.035^{*}$ & ND & ND \\
\hline \multirow[t]{6}{*}{ NRF-8 } & $6 / 10 / 97$ & ND & ND & 2.3 & .18 & $.50^{*}$ & $.004 *$ \\
\hline & $9 / 4 / 97$ & ND & $.005^{*}$ & 2.1 & $.026^{*}$ & $.22 *$ & $.008^{*}$ \\
\hline & $11 / 17 / 97$ & ND & ND & $2.0 \mathrm{~S}$ & $.085 *$ & $.56^{*}$ & ND \\
\hline & $2 / 10 / 98$ & ND & ND & 2.2 & $.046^{*}$ & $.20^{*}$ & ND B \\
\hline & $5 / 13 / 98$ & $.22 *$ & $.006^{*}$ & 2.1 & $.052^{*}$ & ND & ND \\
\hline & $8 / 5 / 98$ & $.19 *$ & ND & 1.9 & $.027^{*}$ & ND & $.016^{*}$ \\
\hline QAS-64B & $8 / 5 / 98$ & $.22^{*}$ & ND & $.031^{*}$ & ND & ND & ND \\
\hline NRF-8 & $11 / 3 / 98$ & ND & ND & 2.3 & $.023^{*}$ & ND & .23 \\
\hline \multirow[t]{2}{*}{ NRF-9 } & $6 / 10 / 97$ & ND & ND & 2.5 & .20 & $.56^{*}$ & ND \\
\hline & $9 / 4 / 97$ & ND & $.005 *$ & 2.2 & .089 & $.22^{*}$ & $.008 *$ \\
\hline QAS-56R & $9 / 4 / 97$ & ND & $.006^{*}$ & 2.2 & $.027 *$ & $.42 *$ & $.010^{*}$ \\
\hline \multirow[t]{3}{*}{ NRF-9 } & $11 / 18 / 97$ & ND & ND & 2.4 & $.042 *$ & $.69 *$ & ND \\
\hline & $2 / 10 / 98$ & ND & $.003 * \mathrm{~B}$ & 2.4 & $.038^{*}$ & $.32 *$ & NDB \\
\hline & $5 / 13 / 98$ & $.18 *$ & $.003^{*}$ & 2.1 & $.035 *$ & ND & ND \\
\hline QAS-62B & $5 / 13 / 98$ & ND & $.004 *$ & ND & $.022^{*}$ & ND & ND \\
\hline \multirow[t]{2}{*}{ NRF-9 } & $8 / 4 / 98$ & ND & ND & $2.1 \mathrm{Q}$ & $.033^{*}$ & ND & .05 \\
\hline & $11 / 3 / 98$ & $.079 *$ & ND & 2.4 & $.026^{*}$ & ND & .069 \\
\hline \multirow[t]{6}{*}{ NRF-10 } & $6 / 11 / 97$ & ND & ND & 2.2 & .21 & $.47^{*}$ & $.003^{*}$ \\
\hline & $9 / 4 / 97$ & ND & $.005^{*}$ & 1.9 & $.042^{*}$ & $.48^{*}$ & $.004 *$ \\
\hline & $11 / 18 / 97$ & ND & ND & 1.9 & $.047 *$ & $.54^{*}$ & ND \\
\hline & $2 / 10 / 98$ & ND & $.004 * \mathrm{~B}$ & 2.0 & .16 & ND & $.009 * \mathrm{~B}$ \\
\hline & $5 / 13 / 98$ & $.37 *$ & $.004^{*}$ & 1.9 & $.04 *$ & ND & ND \\
\hline & $8 / 5 / 98$ & $.063^{*}$ & ND & 1.8 & $.027^{*}$ & ND & $.021^{*}$ \\
\hline
\end{tabular}


Table 7. Concentrations of dissolved and total nutrients, total organic carbon, and total organic halogens in water, Naval Reactors Facility and vicinity-Continued

\begin{tabular}{|c|c|c|c|c|c|c|c|}
\hline $\begin{array}{c}\text { Sample } \\
\text { identifier }\end{array}$ & $\begin{array}{c}\text { Date } \\
\text { sampled } \\
\mathrm{m} / \mathrm{d} / \mathbf{y}\end{array}$ & $\begin{array}{c}\text { Kjeldahl } \\
\text { nitrogen } \\
\text { (total) }\end{array}$ & $\begin{array}{c}\text { Nitrite } \\
\text { (dissolved) }\end{array}$ & $\begin{array}{c}\text { Nitrite plus } \\
\text { nitrate (total) }\end{array}$ & $\begin{array}{l}\text { Phosphorus } \\
\text { (total) }\end{array}$ & $\begin{array}{c}\text { Total } \\
\text { organic } \\
\text { carbon }\end{array}$ & $\begin{array}{c}\text { Total } \\
\text { organic } \\
\text { halogens }\end{array}$ \\
\hline NRF-10 & $11 / 3 / 98$ & ND & ND & 2.1 & $.025^{*}$ & ND & .055 \\
\hline \multirow[t]{3}{*}{ NRF-11 } & $6 / 11 / 97$ & ND & ND & 2.3 & .20 & $.56 *$ & $.010^{*}$ \\
\hline & 9/4/97 & ND & $.005^{*}$ & 2.0 & $.026^{*}$ & $.33 *$ & $.006^{*}$ \\
\hline & $11 / 19 / 97$ & ND & ND & 2.3 & $.041^{*}$ & $.41 *$ & $.008 *$ \\
\hline QAS-58R & $11 / 19 / 97$ & ND & $.004^{*}$ & 2.1 & $.040^{*}$ & $.40^{*}$ & ND \\
\hline \multirow{4}{*}{ NRF-11 } & $2 / 11 / 98$ & ND & ND & 2.2 & $.045^{*}$ & ND & ND B \\
\hline & $5 / 13 / 98$ & $.22 *$ & $.004^{*}$ & 2.1 & $.046^{*}$ & ND & ND \\
\hline & $8 / 5 / 98$ & $.26 *$ & ND & 2.0 & $.034^{*}$ & ND & $.024^{*}$ \\
\hline & $11 / 4 / 98$ & ND & ND & 2.4 & $.039 *$ & ND & .066 \\
\hline NRF-12 & $6 / 5 / 97$ & ND & ND & 2.3 & .24 & $.31^{*}$ & $.009 *$ \\
\hline QAS-53R & $6 / 5 / 97$ & ND & ND & 2.3 & .28 & $.33 *$ & $.005^{*}$ \\
\hline \multirow[t]{6}{*}{ NRF-12 } & $9 / 4 / 97$ & ND & $.005^{*}$ & 2.1 & $.028^{*}$ & $.42 *$ & $.011^{*}$ \\
\hline & $11 / 18 / 97$ & ND & ND & 2.1 & $.038^{*}$ & $.62^{*}$ & $.009 *$ \\
\hline & $2 / 11 / 98$ & ND & ND & 2.3 & $.049^{*}$ & ND & $.011 * \mathrm{~B}$ \\
\hline & $5 / 13 / 98$ & .30 & $.005^{*}$ & 2.1 & $.037^{*}$ & ND & ND \\
\hline & $8 / 5 / 98$ & .55 & ND & 2.0 & $.023^{*}$ & ND & $.019^{*}$ \\
\hline & $11 / 4 / 98$ & $.15^{*}$ & ND & $2.4 \mathrm{Q}$ & $.026^{*}$ & ND & .042 \\
\hline \multirow[t]{7}{*}{ NRF-13 } & $6 / 9 / 97$ & ND & ND & .90 & .48 & $.34^{*}$ & $.012^{*}$ \\
\hline & $9 / 5 / 97$ & ND & $.009 *$ & .80 & .088 & ND & $.014^{*}$ \\
\hline & $11 / 19 / 97$ & ND & $.006 *$ & .98 & .17 & $.35 *$ & ND \\
\hline & $2 / 11 / 98$ & ND & ND & 1.1 & .079 & ND & $.011 * \mathrm{~B}$ \\
\hline & $5 / 13 / 98$ & $.30^{*}$ & $.007^{*}$ & .83 & .051 & ND & $.02 *$ \\
\hline & $8 / 5 / 98$ & $.32 *$ & ND & .74 & .11 & ND & $.018^{*}$ \\
\hline & $11 / 4 / 98$ & ND & ND & .89 & .10 & ND & $.015^{*}$ \\
\hline USGS 12 & $6 / 9 / 97$ & ND & ND & 2.2 & .17 & $.50^{*}$ & ND \\
\hline QAS-54B & 6/9/97 & ND & ND & .21 & ND & $.36 *$ & ND \\
\hline \multirow[t]{5}{*}{ USGS 12} & $9 / 3 / 97$ & ND & ND & 2.0 & $.027^{*}$ & $.32 *$ & $.006^{*}$ \\
\hline & $11 / 19 / 97$ & ND & $.004^{*}$ & 1.8 & $.035^{*}$ & 3.6 & ND \\
\hline & $2 / 11 / 98$ & ND & ND & 1.6 & $.049 *$ & ND & NDB \\
\hline & $5 / 12 / 98$ & $.27 *$ & $.001^{*}$ & 1.4 & $.022^{*}$ & $.44^{*}$ & ND \\
\hline & $8 / 4 / 98$ & ND & ND & 1.3 & $.032 *$ & ND & .055 \\
\hline QAS-63R & $8 / 4 / 98$ & ND & ND & 1.3 & $.032 *$ & ND & ND \\
\hline USGS 12 & $11 / 4 / 98$ & ND & ND & 1.5 & $.025^{*}$ & $.32 *$ & .048 \\
\hline \multirow[t]{3}{*}{ USGS 97} & $6 / 10 / 97$ & ND & ND & 2.4 & .21 & $.46^{*}$ & ND \\
\hline & $9 / 3 / 97$ & ND & ND & 2.3 & $.026^{*}$ & $.64^{*}$ & $.011^{*}$ \\
\hline & $11 / 18 / 97$ & ND & ND & 2.2 & $.038^{*}$ & 3.7 & ND \\
\hline QAS-57B & $11 / 18 / 97$ & ND & ND & ND & $.022 *$ & ND & ND \\
\hline \multirow[t]{4}{*}{ USGS 97} & $2 / 10 / 98$ & ND & $.005 * \mathrm{~B}$ & 2.3 & $.045^{*}$ & ND & ND B \\
\hline & $5 / 12 / 98$ & $.21^{*}$ & $.001^{*}$ & 2.2 & $.022^{*}$ & $.39 *$ & $.015^{*}$ \\
\hline & $8 / 4 / 98$ & ND & ND & $2.0 \mathrm{Q}$ & $.029 *$ & ND & ND \\
\hline & $11 / 3 / 98$ & ND & ND & 2.4 & $.03 *$ & $.35 *$ & .073 \\
\hline \multirow[t]{2}{*}{ USGS 98} & $6 / 10 / 97$ & ND & ND & 1.5 & .21 & $.30 *$ & ND \\
\hline & 9/3/97 & ND & ND & 1.2 & $.019 *$ & $.25 *$ & ND \\
\hline
\end{tabular}


Table 7. Concentrations of dissolved and total nutrients, total organic carbon, and total organic halogens in water, Naval Reactors Facility and vicinity-Continued

\begin{tabular}{|c|c|c|c|c|c|c|c|}
\hline $\begin{array}{c}\text { Sample } \\
\text { identifier }\end{array}$ & $\begin{array}{c}\text { Date } \\
\text { sampled } \\
\mathbf{m} / \mathbf{d} / \mathbf{y}\end{array}$ & $\begin{array}{c}\text { Kjeldahl } \\
\text { nitrogen } \\
\text { (total) }\end{array}$ & $\begin{array}{c}\begin{array}{c}\text { Nitrite } \\
\text { (dissolved) }\end{array}\end{array}$ & $\begin{array}{l}\text { Nitrite plus } \\
\text { nitrate (total) }\end{array}$ & $\begin{array}{l}\text { Phosphorus } \\
\text { (total) }\end{array}$ & $\begin{array}{c}\text { Total } \\
\text { organic } \\
\text { carbon }\end{array}$ & $\begin{array}{c}\text { Total } \\
\text { organic } \\
\text { halogens }\end{array}$ \\
\hline \multirow[t]{2}{*}{ USGS 98} & $11 / 18 / 97$ & ND & ND & 1.3 & $.03^{*}$ & $.41^{*}$ & ND \\
\hline & $2 / 10 / 98$ & ND & $.003 * \mathrm{~B}$ & 1.5 & $.035^{*}$ & ND & ND B \\
\hline QAS-60B & $2 / 10 / 98$ & ND & ND & ND & $.022^{*}$ & ND & NDB \\
\hline \multirow[t]{3}{*}{ USGS 98} & $5 / 12 / 98$ & $.22 *$ & $.001 *$ & 1.2 & $.017^{*}$ & $.55 *$ & ND \\
\hline & $8 / 4 / 98$ & ND & ND & 1.1 & $.024 *$ & ND & $.014 *$ \\
\hline & $11 / 3 / 98$ & ND & ND & 1.4 & $.026^{*}$ & ND & .09 \\
\hline \multirow[t]{2}{*}{ USGS 99} & $6 / 10 / 97$ & ND & ND & 2.0 & .15 & $.50^{*}$ & ND \\
\hline & $9 / 3 / 97$ & ND & ND & 1.8 & $.022^{*}$ & $.20 *$ & $.005^{*}$ \\
\hline QAS-55B & $9 / 3 / 97$ & ND & ND & .12 & ND & ND & ND \\
\hline \multirow[t]{5}{*}{ USGS 99} & $11 / 18 / 97$ & .50 & .036 & 1.7 & $.038^{*}$ & $.64 *$ & ND \\
\hline & $2 / 10 / 98$ & ND & ND & 1.9 & $.04 *$ & ND & ND B \\
\hline & $5 / 12 / 98$ & .18 & $.001 *$ & 1.6 & $.036^{*}$ & $.38 *$ & $.008 *$ \\
\hline & $8 / 4 / 98$ & ND & ND & 1.5 & $.022 *$ & ND & $.015^{*}$ \\
\hline & $11 / 3 / 98$ & ND & ND & 1.9 & $.027 *$ & ND & .03 \\
\hline QAS-66B & $11 / 3 / 98$ & $.095^{*}$ & ND & ND & $.016^{*}$ & ND & .094 \\
\hline \multirow[t]{7}{*}{ USGS 102} & $6 / 9 / 97$ & ND & ND & 2.3 & .19 & $.55^{*}$ & $.012^{*}$ \\
\hline & $9 / 3 / 97$ & ND & ND & 2.3 & $.027^{*}$ & $.30 *$ & $.006^{*}$ \\
\hline & $11 / 17 / 97$ & ND & ND & $2.2 \mathrm{~S}$ & $.034^{*}$ & $.56^{*}$ & ND \\
\hline & $2 / 9 / 98$ & ND & $.004 *$ & 2.2 & $.047^{*}$ & ND & ND B \\
\hline & $5 / 11 / 98$ & $.21^{*}$ & $.001^{*}$ & 2.1 & $.022 *$ & $.45^{*}$ & ND \\
\hline & $8 / 3 / 98$ & ND & ND & 1.9 & $.026 *$ & ND & $.022^{*}$ \\
\hline & $11 / 2 / 98$ & ND & ND & $2.1 \mathrm{Q}$ & $.032 *$ & $.23^{*}$ & ND \\
\hline QAS-65R & $11 / 2 / 98$ & ND & ND & $2.1 \mathrm{Q}$ & $.039 *$ & ND & 70.2 \\
\hline
\end{tabular}


Table 8. Statistical parameters for dissolved and total nutrients, total organic carbon, and total organic halogens, by well

[See figure 2 for well locations. Units are milligrams per liter. Nitrite dissolved, all other constituents total. Values are derived from table 7. Quality-assurance replicates are included in the calculation of statistical parameters. Mean and median sample size: includes all samples with concentrations greater than laboratory reporting limit and estimated concentrations. ${ }^{*}$, results were estimated; ND, not detected]

\begin{tabular}{|c|c|c|c|c|c|c|}
\hline \multirow[b]{2}{*}{ Constituent } & \multicolumn{6}{|c|}{ Statistical parameter } \\
\hline & Minimum & Maximum & Median & Mean & Sample size & $\begin{array}{c}\text { Mean and } \\
\text { median sample } \\
\text { size }\end{array}$ \\
\hline \multicolumn{7}{|c|}{ NRF-6 } \\
\hline Kjeldahl nitrogen & ND & $0.37^{*}$ & $0.32 *$ & $0.28^{*}$ & 8 & 3 \\
\hline Nitrite & ND & $.004^{*}$ & $.003 *$ & $.003^{*}$ & 8 & 3 \\
\hline Nitrite plus nitrate & 1.6 & 2.0 & 1.85 & 1.8 & 8 & 8 \\
\hline Phosphorous & .081 & .20 & .115 & .12 & 8 & 8 \\
\hline Total organic carbon & ND & $.85^{*}$ & $.44 *$ & $.51^{*}$ & 8 & 7 \\
\hline Total organic halogens & ND & .059 & $.020 *$ & $.024^{*}$ & 8 & 7 \\
\hline \multicolumn{7}{|c|}{ NRF-7 } \\
\hline Kjeldahl nitrogen & ND & $.18^{*}$ & $.12 *$ & $.13^{*}$ & 8 & 3 \\
\hline Nitrite & ND & $.003^{*}$ & $.002 *$ & $.002^{*}$ & 8 & 3 \\
\hline Nitrite plus nitrate & .44 & .72 & .47 & .54 & 8 & 8 \\
\hline Phosphorous & $.022^{*}$ & .17 & .029 & $.046^{*}$ & 8 & 8 \\
\hline \multicolumn{7}{|c|}{ NRF.8 } \\
\hline Nitrite plus nitrate & 1.9 & 2.3 & 2.1 & 2.1 & 7 & 7 \\
\hline Phosphorous & $.023^{*}$ & .18 & $.046^{*}$ & .063 & 7 & 7 \\
\hline Total organic carbon & ND & $.56^{*}$ & $.36^{*}$ & $.37 *$ & 7 & 4 \\
\hline Total organic halogens & ND & .23 & $.012^{*}$ & $.064^{*}$ & 7 & 4 \\
\hline \multicolumn{7}{|c|}{ NRF-9 } \\
\hline Nitrite & ND & $.006^{*}$ & $.004^{*}$ & $.004^{*}$ & 8 & 4 \\
\hline Nitrite plus nitrate & 2.1 & 2.5 & 2.3 & 2.3 & 8 & 8 \\
\hline Phosphorous & $.026 *$ & .20 & $.0365^{*}$ & $.061^{*}$ & 8 & 8 \\
\hline Total organic carbon & ND & $.69^{*}$ & $.42 *$ & $.44^{*}$ & 8 & 5 \\
\hline Total organic halogens & ND & .069 & $.03^{*}$ & $.034^{*}$ & 8 & 4 \\
\hline \multicolumn{7}{|c|}{ NRF-10 } \\
\hline Nitrite & ND & $.005^{*}$ & $.004^{*}$ & $.004^{*}$ & 7 & 3 \\
\hline Nitrite plus nitrate & 1.8 & 2.2 & 1.9 & 2.0 & 7 & 7 \\
\hline Phosphorous & $.025^{*}$ & .21 & $.042 *$ & $.079 *$ & 7 & 7 \\
\hline Total organic carbon & ND & $.54^{*}$ & $.48 *$ & $.50^{*}$ & 7 & 3 \\
\hline Total organic halogens & ND & .055 & $.009 *$ & $.018^{*}$ & 7 & 5 \\
\hline \multicolumn{7}{|c|}{ NRF-11 } \\
\hline Nitrite & ND & $.005^{*}$ & $.004^{*}$ & $.004^{*}$ & 8 & 3 \\
\hline Nitrite plus nitrate & 2.0 & 2.4 & 2.15 & 2.2 & 8 & 8 \\
\hline Phosphorous & $.025 *$ & .20 & $.0405 *$ & $.059^{*}$ & 8 & 8 \\
\hline Total organic carbon & ND & $.56^{*}$ & $.405 *$ & $.42 *$ & 8 & 4 \\
\hline Total organic halogens & ND & .066 & $.010^{*}$ & $.023^{*}$ & 8 & 5 \\
\hline
\end{tabular}


Table 8. Statistical parameters for dissolved and total nutrients, total organic carbon, and total organic halogens, by well-Continued

\begin{tabular}{|c|c|c|c|c|c|c|}
\hline \multirow[b]{2}{*}{ Constituent } & \multicolumn{6}{|c|}{ Statistical parameter } \\
\hline & Minimum & Maximum & Median & Mean & Sample size & $\begin{array}{c}\text { Mean and } \\
\text { median sample } \\
\text { size }\end{array}$ \\
\hline \multicolumn{7}{|c|}{ NRF-12 } \\
\hline Kjeldahl nitrogen & ND & .55 & .30 & $.33^{*}$ & 8 & 3 \\
\hline Nitrite plus nitrate & 2.0 & 2.4 & 2.2 & 2.2 & 8 & 8 \\
\hline Phosphorous & $.023^{*}$ & .28 & $.0375^{*}$ & $.090^{*}$ & 8 & 8 \\
\hline Total organic carbon & ND & $.62^{*}$ & $.375^{*}$ & $.42 *$ & 8 & 4 \\
\hline Total organic halogens & ND & .042 & $.011^{*}$ & $.015^{*}$ & 8 & 7 \\
\hline \multicolumn{7}{|c|}{ NRF-13 } \\
\hline Nitrite & ND & $.009 *$ & $.007 *$ & $.007^{*}$ & 7 & 3 \\
\hline Nitrite plus nitrate & .74 & 1.1 & .89 & .89 & 7 & 7 \\
\hline Phosphorous & .051 & .48 & .10 & $.15^{*}$ & 7 & 7 \\
\hline Total organic halogens & ND & $.02 *$ & $.0145^{*}$ & $.015^{*}$ & 7 & 6 \\
\hline \multicolumn{7}{|c|}{ USGS 12} \\
\hline Nitrite plus nitrate & 1.3 & 2.2 & 1.55 & 1.6 & 8 & 8 \\
\hline Phosphorous & $.022^{*}$ & .17 & $.032 *$ & $.049^{*}$ & 8 & 8 \\
\hline Total organic carbon & ND & 3.6 & $.44 *$ & $1.0 *$ & 8 & 5 \\
\hline Total organic halogens & ND & .055 & .048 & $.036^{*}$ & 8 & 3 \\
\hline \multicolumn{7}{|c|}{ USGS 97} \\
\hline Nitrite plus nitrate & 2.0 & 2.4 & 2.3 & 2.3 & 7 & 7 \\
\hline Phosphorous & $.022 *$ & .21 & $.03 *$ & $.057^{*}$ & 7 & 7 \\
\hline Total organic carbon & ND & 3.7 & $.46^{*}$ & $1.1^{*}$ & 7 & 5 \\
\hline Total organic halogens & ND & .073 & $.015^{*}$ & $.033^{*}$ & 7 & 3 \\
\hline \multicolumn{7}{|c|}{ USGS 98} \\
\hline Nitrite plus nitrate & 1.1 & 1.5 & 1.3 & 1.3 & 7 & 7 \\
\hline Phosphorous & $.017^{*}$ & .21 & $.026^{*}$ & $.052^{*}$ & 7 & 7 \\
\hline Total organic carbon & ND & $.55^{*}$ & $.355^{*}$ & $.38^{*}$ & 7 & 4 \\
\hline \multicolumn{7}{|c|}{ USGS 99} \\
\hline Nitrite plus nitrate & 1.5 & 2.0 & 1.8 & 1.8 & 7 & 7 \\
\hline Phosphorous & $.022 *$ & .15 & $.036 *$ & $.048^{*}$ & 7. & 7 \\
\hline Total organic carbon & ND & $.64^{*}$ & $.44 *$ & $.43^{*}$ & 7 & 4 \\
\hline Total organic halogens & ND & .03 & .0115 & $.014^{*}$ & 7 & 4 \\
\hline \multicolumn{7}{|c|}{ USGS 102} \\
\hline Nitrite plus nitrate & 1.9 & 2.3 & 2.15 & 2.2 & 8 & 8 \\
\hline Phosphorous & $.022 *$ & .19 & $.033^{*}$ & $.052^{*}$ & 8 & 8 \\
\hline Total organic carbon & ND & $.56^{*}$ & $.45^{*}$ & $.42 *$ & 8 & 5 \\
\hline Total organic halogens & ND & .0625 & $.017 *$ & $.026^{*}$ & 8 & 4 \\
\hline
\end{tabular}




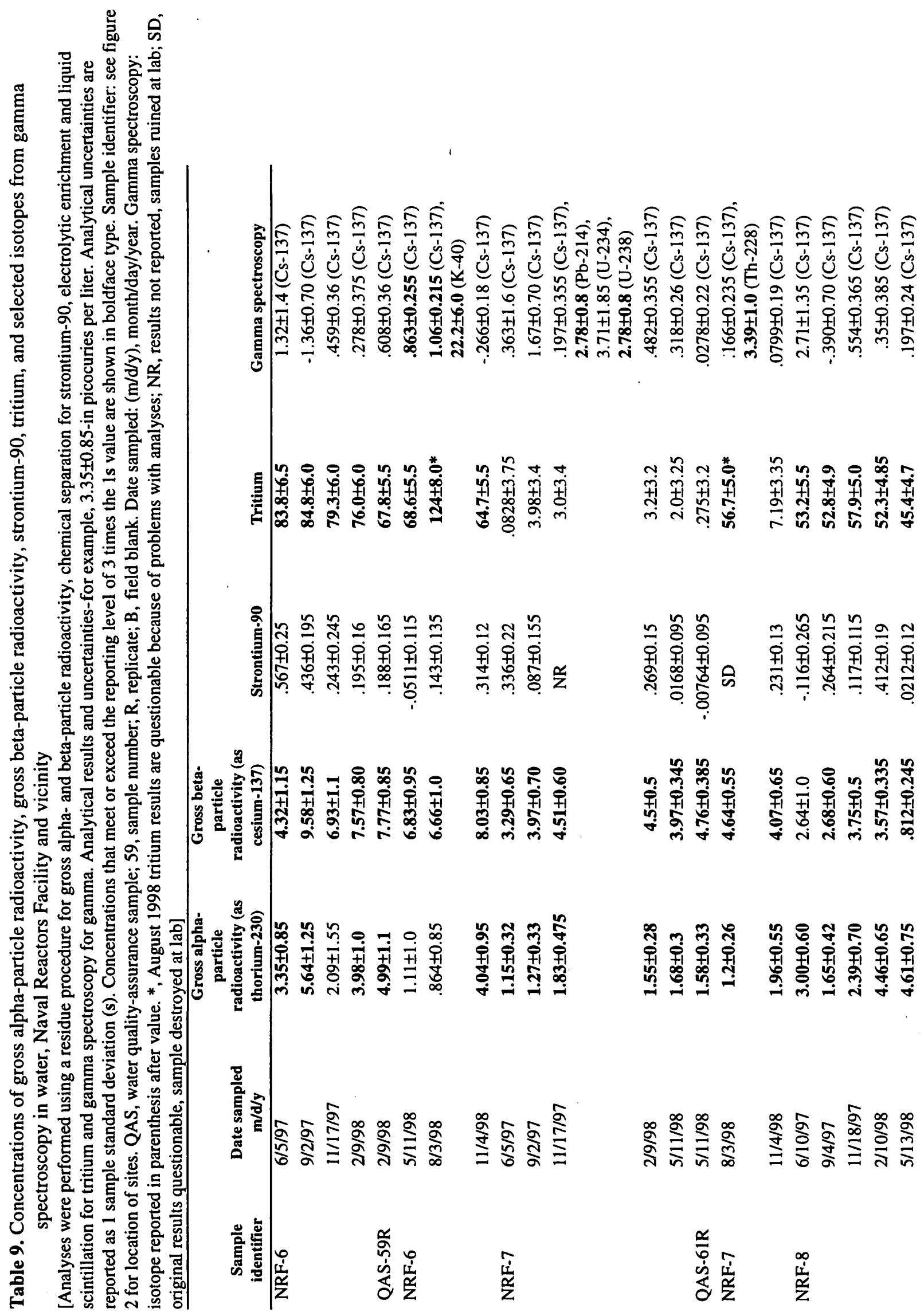




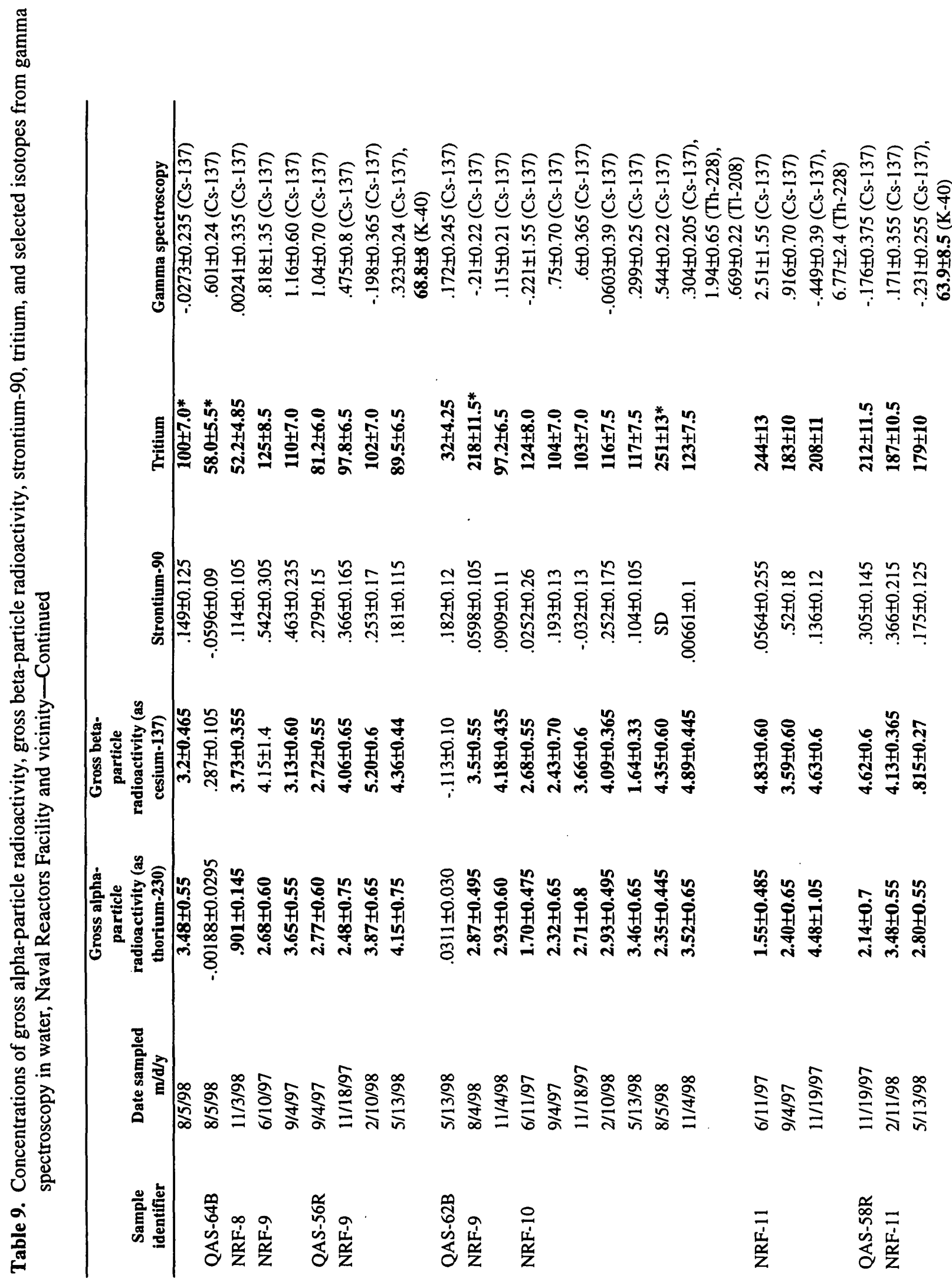




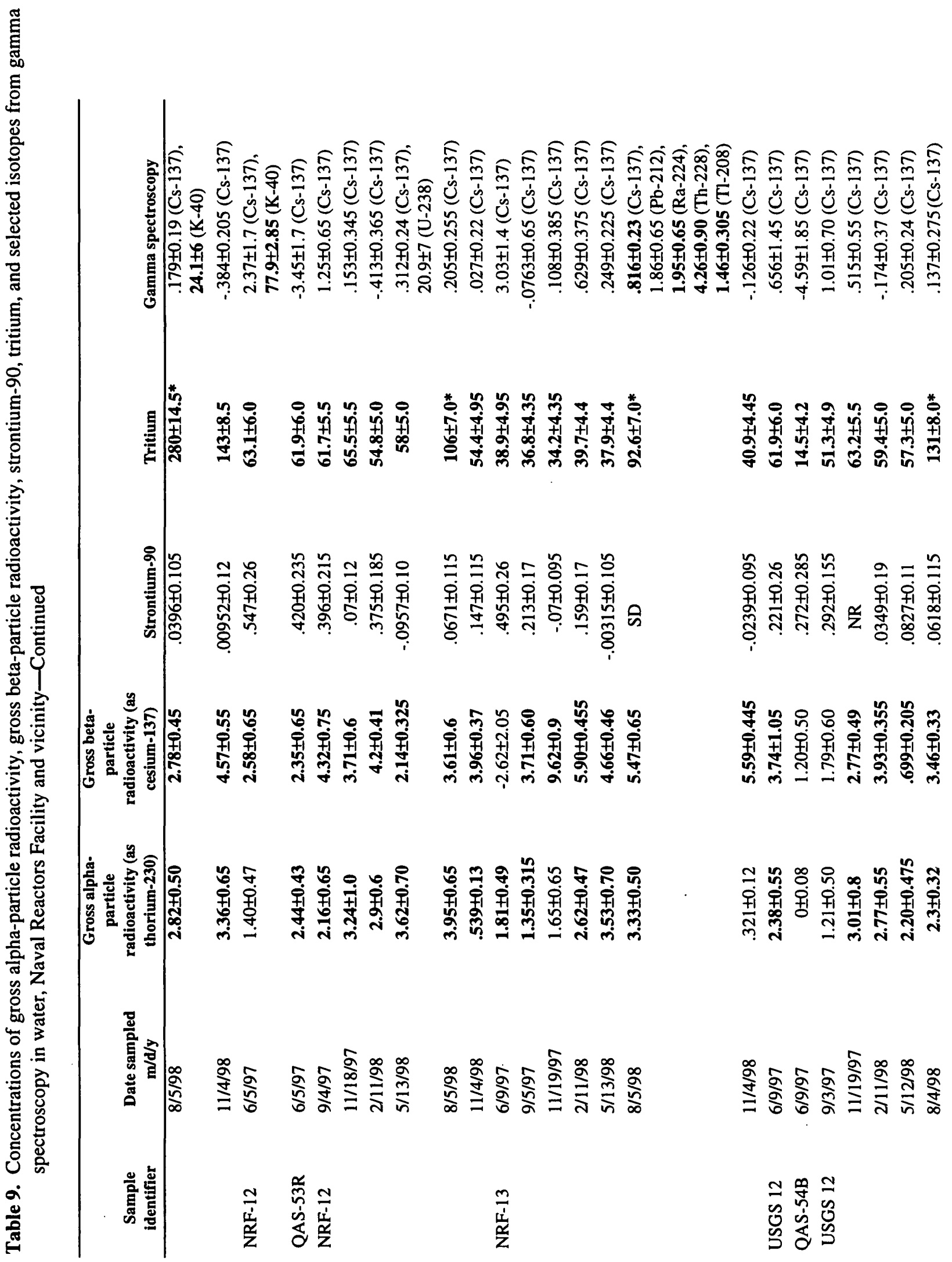




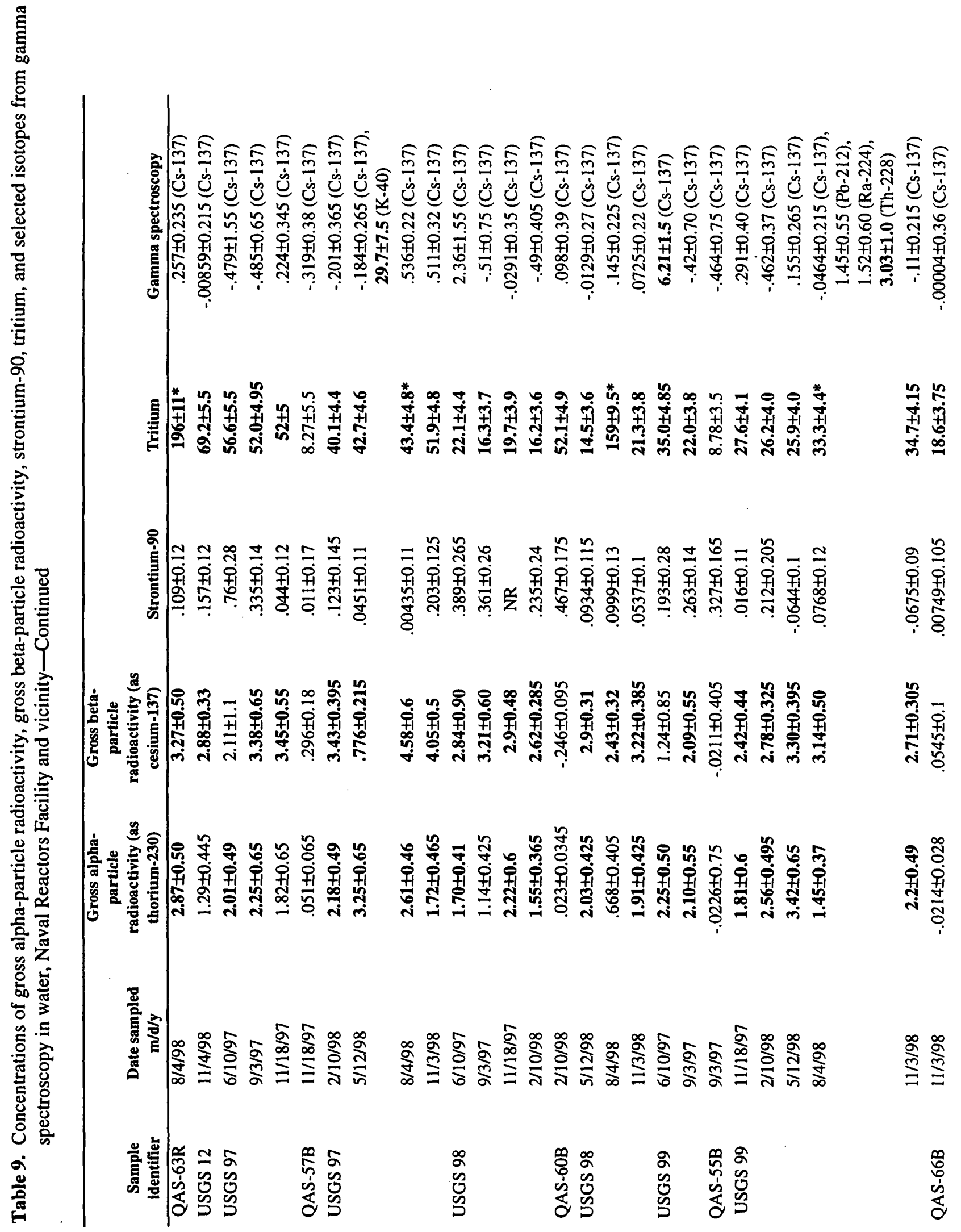




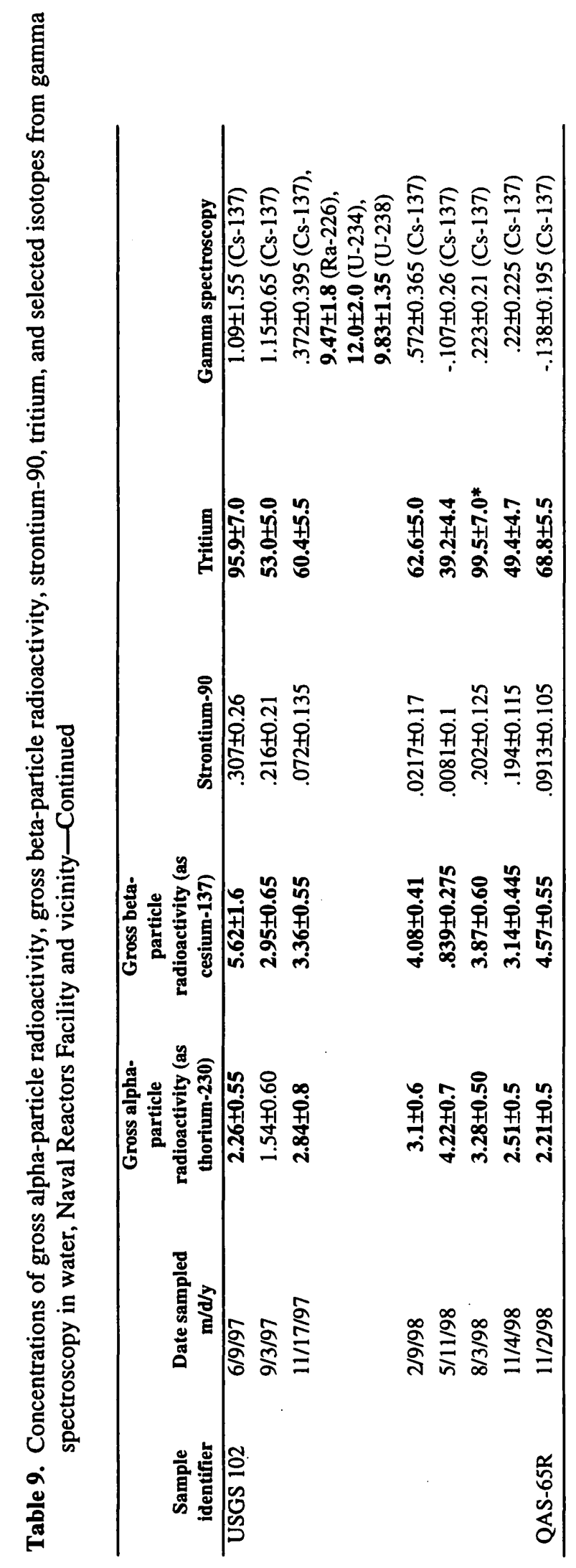


Table 10. Statistical parameters for gross alpha-particle radioactivity, gross beta-particle radioactivity, gamma spectroscopy, strontium-90, and tritium, by well

[See figure 2 for well locations. Gross alpha-particle radioactivity is expressed as thorium-230 in picocuries per liter. Gross betaparticle radioactivity is expressed as cesium-137. Gamma spectroscopy is expressed as cesium-137. Values are derived from table 9. Quality-assurance replicates are included in the calculation of statistical parameters. Questionable tritium results from August 1998 were not used in statistical calculations. See section on calculation of estimated experimental standard error for the estimated uncertainty of the mean concentration. Abbreviations: Th-230, thorium-230; Cs-137, cesium-137]

\begin{tabular}{|c|c|c|c|c|c|}
\hline \multirow[b]{2}{*}{ Constituent } & \multicolumn{5}{|c|}{ Statistical parameter } \\
\hline & Minimum & Maximum & Median & Mean & $\begin{array}{c}\text { Sample } \\
\text { size }\end{array}$ \\
\hline \multicolumn{6}{|c|}{ NRF-6 } \\
\hline Gross alpha as Th-230 & $.864 \pm 0.85$ & $5.64 \pm 1.25$ & $3.665 \pm 0.656$ & $3.26 \pm 0.62$ & 8 \\
\hline Gross beta as Cs-137 & $4.32 \pm 1.15$ & $9.58 \pm 1.25$ & $7.25 \pm 0.68$ & $7.21 \pm 0.53$ & 8 \\
\hline Gamma as Cs-137 & $-1.36 \pm 0.70$ & $1.32 \pm 1.4$ & $.534 \pm 0.25$ & $.37 \pm 0.30$ & 8 \\
\hline Strontium-90 & $-.0511 \pm 0.115$ & $.567 \pm 0.25$ & $.219 \pm 0.146$ & $.254 \pm 0.067$ & 8 \\
\hline Tritium & $64.7 \pm 5.5$ & $84.8 \pm 6.0$ & $76.0 \pm 6.0$ & $75 \pm 3.1$ & 7 \\
\hline \multicolumn{6}{|c|}{ NRF-7 } \\
\hline Gross alpha as Th-230 & $1.15 \pm 0.32$ & $1.96 \pm 0.55$ & $1.565 \pm 0.216$ & $1.53 \pm 0.105$ & 8 \\
\hline Gross beta as Cs- 137 & $3.29 \pm 0.65$ & $4.76 \pm 0.385$ & $4.285 \pm 0.41$ & $4.21 \pm 0.17$ & 8 \\
\hline Gamma as Cs-137 & $.0278 \pm 0.22$ & $1.67 \pm 0.70$ & $.2575 \pm 0.22$ & $.413 \pm 0.187$ & 8 \\
\hline Strontium-90 & $-.00764 \pm 0.095$ & $.336 \pm 0.22$ & $.159 \pm 0.101$ & $.155 \pm 0.058$ & 6 \\
\hline Tritium & $.0828 \pm 1.05$ & $7.19 \pm 3.35$ & $3.98 \pm 3.4$ & $4.12 \pm 0.88$ & 7 \\
\hline \multicolumn{6}{|c|}{ NRF-8 } \\
\hline Gross alpha as Th-230 & $.901 \pm 0.145$ & $4.61 \pm 0.75$ & $3.00 \pm 0.60$ & $2.93 \pm 0.52$ & 7 \\
\hline Gross beta as Cs- 137 & $.812 \pm 0.245$ & $3.75 \pm 0.5$ & $3.2 \pm 0.465$ & $2.91 \pm 0.39$ & 7 \\
\hline Gamma as Cs-137 & $-.39 \pm 0.70$ & $2.71 \pm 1.35$ & $.197 \pm 0.24$ & $.485 \pm 0.388$ & 7 \\
\hline Strontium-90 & $-.116 \pm 0.265$ & $.412 \pm 0.19$ & $.117 \pm 0.115$ & $.137 \pm 0.064$ & 7 \\
\hline Tritium & $45.4 \pm 4.7$ & $57.9 \pm 5.0$ & $52.55 \pm 3.43$ & $52.3 \pm 1.63$ & 6 \\
\hline \multicolumn{6}{|c|}{ NRF-9 } \\
\hline Gross alpha as Th-230 & $2.48 \pm 0.75$ & $4.15 \pm 0.75$ & $2.90 \pm 0.39$ & $3.18 \pm 0.22$ & 8 \\
\hline Gross beta as Cs- 137 & $2.72 \pm 0.55$ & $5.20 \pm 0.6$ & $4.105 \pm 0.77$ & $3.91 \pm 0.27$ & 8 \\
\hline Gamma as Cs-137 & $-.21 \pm 0.22$ & $1.16 \pm 0.6$ & $.399 \pm 0.418$ & $.44 \pm 0.19$ & 8 \\
\hline Strontium-90 & $.0598 \pm 0.105$ & $.542 \pm 0.305$ & $.266 \pm 0.113$ & $.279 \pm 0.06$ & 8 \\
\hline Tritium & $81.2 \pm 6.0$ & $125 \pm 8.5$ & $97.8 \pm 6.5$ & $100 \pm 5.4$ & 7 \\
\hline \multicolumn{6}{|c|}{ NRF-10 } \\
\hline Gross alpha as Th-230 & $1.70 \pm 0.475$ & $3.52 \pm 0.65$ & $2.71 \pm 0.8$ & $2.71 \pm 0.25$ & 7 \\
\hline Gross beta as Cs- 137 & $1.64 \pm 0.33$ & $4.89 \pm 0.445$ & $3.66 \pm 0.6$ & $3.39 \pm 0.44$ & 7 \\
\hline Gamma as Cs-137 & $-.221 \pm 1.55$ & $.75 \pm 0.70$ & $.304 \pm 0.205$ & $.316 \pm 0.134$ & 7 \\
\hline Strontium-90 & $-.032 \pm 0.13$ & $.252 \pm 0.175$ & $.0646 \pm 0.14$ & $.091 \pm 0.046$ & 6 \\
\hline Tritium & $103 \pm 7.0$ & $124 \pm 8.0$ & $116.5 \pm 5.3$ & $114 \pm 3.7$ & 6 \\
\hline \multicolumn{6}{|c|}{ NRF-11 } \\
\hline $\begin{array}{l}\text { Gross alpha as Th-230 } \\
\text { Gross beta as Cs- } 137\end{array}$ & $\begin{array}{l}1.55 \pm 0.485 \\
.815 \pm 0.27\end{array}$ & $\begin{array}{l}4.48 \pm 1.05 \\
4.83 \pm 0.60\end{array}$ & $\begin{array}{l}2.81 \pm 0.31 \\
4.35 \pm 0.33\end{array}$ & $\begin{array}{l}2.88 \pm 0.32 \\
3.75 \pm 0.48\end{array}$ & $\begin{array}{l}8 \\
8\end{array}$ \\
\hline Gamma as Cs-137 & $-.449 \pm 0.39$ & $2.51 \pm 1.55$ & $-.0025 \pm 0.258$ & $.317 \pm 0.349$ & 8 \\
\hline Strontium-90 & $.00952 \pm 0.12$ & $.52 \pm 0.18$ & $.1555 \pm 0.087$ & $.20 \pm 0.064$ & 8 \\
\hline
\end{tabular}


Table 10. Statistical parameters for gross alpha-particle radioactivity, gross beta-particle radioactivity, gamma spectroscopy, strontium-90, and tritium, by well-Continued

\begin{tabular}{|c|c|c|c|c|c|}
\hline \multirow[b]{2}{*}{ Constituent } & \multicolumn{5}{|c|}{ Statistical parameter } \\
\hline & Minimum & Maximum & Median & Mean & $\begin{array}{c}\text { Sample } \\
\text { size }\end{array}$ \\
\hline \multicolumn{6}{|c|}{ NRF-11-continued } \\
\hline Tritium & $143 \pm 8.5$ & $244 \pm 13$ & $187 \pm 10.5$ & $194 \pm 12$ & 7 \\
\hline \multicolumn{6}{|c|}{ NRF-12 } \\
\hline Gross alpha as Th-230 & $.539 \pm 0.13$ & $3.95 \pm 0.65$ & $2.67 \pm 0.37$ & $2.53 \pm 0.41$ & 8 \\
\hline Gross beta as Cs-137 & $2.14 \pm 0.325$ & $4.32 \pm 0.75$ & $3.66 \pm 0.42$ & $3.36 \pm 0.31$ & 8 \\
\hline Gamma as Cs-137 & $-3.45 \pm 1.7$ & $2.37 \pm 1.7$ & $.179 \pm 0.216$ & $.057 \pm 0.59$ & 8 \\
\hline Strontium-90 & $-.0957 \pm 0.1$ & $.547 \pm 0.26$ & $.261 \pm 0.109$ & $.241 \pm 0.079$ & 8 \\
\hline Tritium & $54.4 \pm 4.95$ & $65.5 \pm 5.5$ & $61.7 \pm 5.5$ & $59.9 \pm 1.6$ & 7 \\
\hline \multicolumn{6}{|c|}{ NRF-13 } \\
\hline Gross alpha as Th-230 & $.321 \pm 0.12$ & $3.53 \pm 0.70$ & $1.81 \pm 0.49$ & $2.09 \pm 0.43$ & 7 \\
\hline Gross beta as Cs- 137 & $-2.62 \pm 2.05$ & $9.62 \pm 0.9$ & $5.47 \pm 0.65$ & $4.62 \pm 1.39$ & 7 \\
\hline Gamma as Cs- 137 & $-.126 \pm 0.22$ & $3.03 \pm 1.4$ & $.249 \pm 0.225$ & $.661 \pm 0.42$ & 7 \\
\hline Strontium-90 & $-.07 \pm 0.095$ & $.495 \pm 0.26$ & $.078 \pm 0.1$ & $.128 \pm 0.086$ & 6 \\
\hline Tritium & $34.2 \pm 4.35$ & $40.9 \pm 4.45$ & $38.4 \pm 3.31$ & $38.1 \pm 0.97$ & 6 \\
\hline \multicolumn{6}{|c|}{ USGS 12} \\
\hline Gross alpha as Th-230 & $1.21 \pm 0.50$ & $3.01 \pm 0.8$ & $2.34 \pm 0.32$ & $2.25 \pm 0.24$ & 8 \\
\hline Gross beta as Cs- 137 & $.699 \pm 0.205$ & $3.93 \pm 0.355$ & $3.075 \pm 0.30$ & $2.82 \pm 0.38$ & 8 \\
\hline Gamma as Cs-137 & $-.174 \pm 0.37$ & $1.01 \pm 0.70$ & $.231 \pm 0.168$ & $.325 \pm 0.136$ & 8 \\
\hline Strontium-90 & $.0349 \pm 0.19$ & $.292 \pm 0.155$ & $.109 \pm 0.12$ & $.137 \pm 0.035$ & 7 \\
\hline Tritium & $51.3 \pm 4.9$ & $69.2 \pm 5.5$ & $60.65 \pm 3.9$ & $60.4 \pm 2.5$ & 6 \\
\hline \multicolumn{6}{|c|}{ USGS 97} \\
\hline Gross alpha as Th-230 & $1.72 \pm 0.465$ & $3.25 \pm 0.65$ & $2.18 \pm 0.49$ & $2.26 \pm 0.2$ & 7 \\
\hline Gross beta as Cs-137 & $.776 \pm 0.215$ & $4.58 \pm 0.6$ & $3.43 \pm 0.395$ & $3.11 \pm 0.48$ & 7 \\
\hline Gamma as Cs-137 & $-.485 \pm 0.65$ & $.536 \pm 0.22$ & $-.184 \pm 0.265$ & $-.011 \pm 0.165$ & 7 \\
\hline Strontium-90 & $.00435 \pm 0.11$ & $.76 \pm 0.28$ & $.123 \pm 0.145$ & $.216 \pm 0.104$ & 7 \\
\hline Tritium & $40.1 \pm 4.4$ & $56.6 \pm 5.5$ & $51.95 \pm 3.4$ & $49.2 \pm 2.6$ & 6 \\
\hline \multicolumn{6}{|c|}{ USGS 98} \\
\hline Gross alpha as Th-230 & $.668 \pm 0.405$ & $2.22 \pm 0.6$ & $1.70 \pm 0.41$ & $1.60 \pm 0.20$ & 7 \\
\hline Gross beta as Cs-137 & $2.43 \pm 0.32$ & $3.22 \pm 0.385$ & $2.9 \pm 0.31$ & $2.87 \pm 0.11$ & 7 \\
\hline Gamma as Cs-137 & $-.51 \pm 0.75$ & $2.36 \pm 1.55$ & $-.0129 \pm 0.27$ & $.219 \pm 0.37$ & 7 \\
\hline Strontium-90 & $.0537 \pm 0.1$ & $.389 \pm 0.265$ & $.16745 \pm 0.136$ & $.205 \pm 0.059$ & 6 \\
\hline Tritium & $14.5 \pm 3.6$ & $22.1 \pm 4.4$ & $18 \pm 2.7$ & $18.4 \pm 1.3$ & 6 \\
\hline \multicolumn{6}{|c|}{ USGS 99} \\
\hline Gross alpha as Th-230 & $1.45 \pm 0.37$ & $3.42 \pm 0.65$ & $2.2 \pm 0.49$ & $2.26 \pm 0.24$ & 7 \\
\hline Gross beta as Cs- 137 & $1.24 \pm 0.85$ & $3.30 \pm 0.395$ & $2.71 \pm 0.305$ & $2.53 \pm 0.26$ & 7 \\
\hline Gamma as Cs-137 & $-.462 \pm 0.37$ & $6.21 \pm 1.5$ & $-.0464 \pm 0.215$ & $.80 \pm 0.91$ & 7 \\
\hline Strontium-90 & $-.0675 \pm 0.09$ & $.263 \pm 0.14$ & $.0768 \pm 0.12$ & $.09 \pm 0.051$ & 7 \\
\hline Tritium & $22.0 \pm 3.8$ & $35.0 \pm 4.85$ & $26.9 \pm 2.9$ & $28.6 \pm 2.1$ & 6 \\
\hline
\end{tabular}


Table 10. Statistical parameters for gross alpha-particle radioactivity, gross beta-particle radioactivity, gamma spectroscopy, strontium-90, and tritium, by well-Continued

\begin{tabular}{lccccc}
\hline & \multicolumn{5}{c}{ Statistical parameter } \\
\cline { 2 - 6 } \multicolumn{1}{c}{ Constituent } & Minimum & Maximum & Median & Mean & $\begin{array}{c}\text { Sample } \\
\text { size }\end{array}$ \\
\hline & & USGS 102 & & \\
Gross alpha as Th-230 & $1.54 \pm 0.6$ & $4.22 \pm 0.7$ & $2.675 \pm 0.47$ & $2.74 \pm 0.29$ & 8 \\
Gross beta as Cs-137 & $.839 \pm 0.275$ & $5.62 \pm 1.6$ & $3.615 \pm 0.41$ & $3.55 \pm 0.49$ & 8 \\
Gross gamma as Cs-137 & $-.138 \pm 0.195$ & $1.15 \pm 0.65$ & $.2975 \pm 0.22$ & $.423 \pm 0.173$ & 8 \\
Strontium-90 & $.0081 \pm 0.1$ & $.307 \pm 0.26$ & $.14265 \pm 0.078$ & $.139 \pm 0.038$ & 8 \\
Tritium & $39.2 \pm 4.4$ & $95.9 \pm 7.0$ & $60.4 \pm 5.5$ & $61.3 \pm 6.8$ & 7 \\
\hline
\end{tabular}


Table 11. Regulatory volatile organic compounds for which water samples were analyzed

[Analyses were performed by the Quanterra Environmental Services Laboratory using U.S. Environmental Protection Agency method 524.2. Reporting limits are in micrograms per liter]

\begin{tabular}{|c|c|c|c|}
\hline Compound & $\begin{array}{c}\text { Reporting } \\
\text { limit }\end{array}$ & Compound & $\begin{array}{l}\text { Reporting } \\
\text { limit }\end{array}$ \\
\hline Benzene & 1.0 & 1,2-Dichloropropane & 1.0 \\
\hline Bromobenzene & 1.0 & 1,3-Dichloropropane & 1.0 \\
\hline Bromochloromethane & 1.0 & 2,2-Dichloropropane & 1.0 \\
\hline Bromodichloromethane & 1.0 & 1,1-Dichloropropylene & 1.0 \\
\hline Bromoform & 1.0 & cis-1,3-Dichloropropylene & 1.0 \\
\hline Bromomethane & 1.0 & trans-1,3-Dichloropropylene & 1.0 \\
\hline n-Butylbenzene & 1.0 & Ethylbenzene & 1.0 \\
\hline sec-Butylbenzene & 1.0 & Hexachlorobutadiene & 1.0 \\
\hline tert-Butylbenzene & 1.0 & Isopropylbenzene & 1.0 \\
\hline Carbon tetrachloride & 1.0 & 4-Isopropyltoluene & 1.0 \\
\hline Chlorobenzene & 1.0 & Methyl-t-butyl ether (MTBE) & 1.0 \\
\hline Chloroethane & 1.0 & Naphthalene & 1.0 \\
\hline Chloroform & 1.0 & n-Propylbenzene & 1.0 \\
\hline Chloromethane & 1.0 & Styrene & 1.0 \\
\hline 2-Chlorotoluene & 1.0 & 1,1,1,2-Tetrachloroethane & 1.0 \\
\hline 4-Chlorotoluene & 1.0 & 1,1,2,2-Tetrachloroethane & 1.0 \\
\hline Dibromochloromethane & 1.0 & Tetrachloroethylene & 1.0 \\
\hline 1,2-Dibromo-3-chloropropane (DBCP) & 2.0 & Toluene & 1.0 \\
\hline 1,2-Dibromoethane (EDB) & 1.0 & 1,2,3-Trichlorobenzene & 1.0 \\
\hline Dibromomethane & 1.0 & 1,2,4-Trichlorobenzene & 1.0 \\
\hline 1,2-Dichlorobenzene & 1.0 & 1,1,1-Trichloroethane & 1.0 \\
\hline 1,3-Dichlorobenzene & 1.0 & 1,1,2-Trichloroethane & 1.0 \\
\hline 1,4-Dichlorobenzene & 1.0 & Trichloroethylene & 1.0 \\
\hline Dichlorodifluoromethane & 1.0 & Trichlorofluoromethane & 1.0 \\
\hline 1,1-Dichloroethane & 1.0 & 1,2,3,-Trichloropropane & 1.0 \\
\hline 1,2-Dichloroethane & 1.0 & 1,2,4-Trimethylbenzene & 1.0 \\
\hline 1,1-Dichloroethylhene & 1.0 & 1,3,5-Trimethylbenzene & 1.0 \\
\hline cis-1,2-Dichloroethylene & 1.0 & Vinyl chloride & 1.0 \\
\hline trans-1,2-Dichloroethylene & 1.0 & Xylenes (total) & 1.0 \\
\hline Dichloromethane & 1.0 & & \\
\hline
\end{tabular}


Table 12. Base/neutral organic compounds for which water samples were analyzed

[Analyses were performed by the Quanterra Environmental Services Laboratory using U.S. Environmental Protection Agency method 525.2. Method detection limits (MDL) are in micrograms per liter]

\begin{tabular}{lrll}
\hline \multicolumn{1}{c}{ Compound } & MDL & \multicolumn{1}{c}{ Compound } & MDL \\
\hline Acenaphthylene & 0.1 & Diethylphthalate & 1 \\
Alachlor & .1 & Dimethylphthalate & 1 \\
Aldrin & .1 & Endrin & .01 \\
Anthracene & .1 & Fluorene & .1 \\
Atrazine & .1 & Heptachlor & .04 \\
Benzo [a] anthracene & .1 & Heptachlor epoxide & .02 \\
Benzo [b] fluoranthene & .1 & $2,2^{\prime}$, e, ', $, 4,4^{\prime}, 6-$-Heptachlorobiphenyl & .1 \\
Benzo [k] fluoranthene & .1 & Hexachlorobenzene & .1 \\
Benzo [g,h,i] perylene & .1 & $2,2^{\prime}, 4,4^{\prime}, 5,6^{\prime}$-Hexachlorobiphenyl & .1 \\
Benzo [a]pyrene & .02 & Hexachlorocyclopentadiene & .1 \\
gamma-BHC (Lindane) & .02 & Indeno(1,2,3-cd)pyrene & .1 \\
Butylbenzylphthalate & 1 & Methoxychlor & .1 \\
alpha-Chlordane & .1 & $2,2^{\prime}, 3,3^{\prime}, 4,5^{\prime}, 6,6^{\prime}$ '-Octachlorobiphenyl & .1 \\
2-Chlorobiphenyl & .1 & $2,2^{\prime}, 3^{\prime}, 4,6$-Pentachlorobiphenyl & .1 \\
Chrysene & .1 & Pentachlorophenol & .04 \\
Dibenzo [a,h] anthracene & .1 & Phenanthrene & .1 \\
Di-n-butylphthalate & 1 & Pyrene & .1 \\
2,3-Dichlorobiphenyl & .1 & Simazine & .07 \\
Di (2-ethylhexyl) adipate & .6 & $2,2^{\prime}, 4,4^{\prime}$-Tetrachlorobiphenyl & .1 \\
Di(2-ethylhexyl) phthalate & .6 & $2,4,5$-Trichlorobiphenyl & .1 \\
\hline
\end{tabular}

